\title{
Geochemistry of Gold in the Weathering Cycle
}

GE OLOGICA L S URVEY B ULLETIN 1330

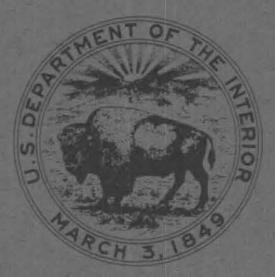





\section{Geochemistry of Gold in the Weathering Cycle}

By HUBERT W. LAKIN, GARY C. CURTIN, and ARTHUR E. HUBERT With chapters

By HANSFORD T. SHACKLETTE and KENNETH G. DOXTADER

G E O L O G I C A L S U R V E Y B U L L E T I N 13330

$A$ study of the solubilization of gold by the formation of chloride, bromide, iodide, thiosulfate, thiocyanide, and cyanide gold complexes and related topics

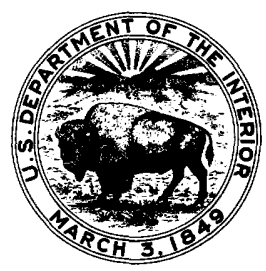




\section{UNITED STATES DEPARTMENT OF THE INTERIOR ROGERS C. B. MORTON, Secretary}

\section{GEOLOGICAL SURVEY}

V. E. McKelvey, Director

Library of Congress-catalog-card No. 74-600187

For sale by the Superintendent of Documents, U.S. Government Printing Office Washington, D.C. 20402 - Price $\$ 1.15$ (paper cover)

Stock Number 2401-02583 


\section{CONTENTS}

Page

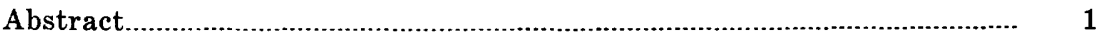

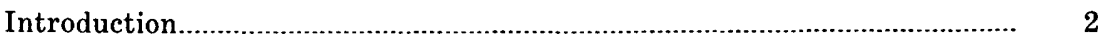

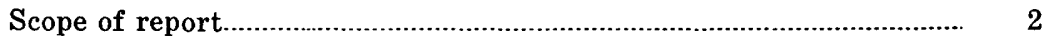

Acknowledgments..................................................................................... 4

Oxidation potential for gold as a function of complex stability.................... 4

Removal of gold from solution by minerals as a function of complex stability

Absorption of gold by plants as a function of complex stability................. 14

Gold chloride...................................................................................... 17

Gold bromide and gold iodide.................................................................... 20

Geochemistry of bromides and iodides................................................... 20

Formation of gold bromide and gold iodide

Gold thiosulfate........................................................................................ 26

Geochemistry of the thiosulfate ion..................................................... 26

Formation of gold thiosulfate............................................................... 28

Gold thiocyanate............................................................................................. 29

Geochemistry of the thiocyanate ion....................................................... 29

Formation of gold thiocyanate............................................................. 31

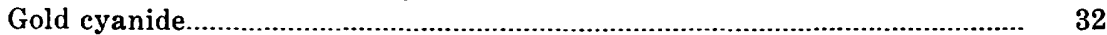

Geochemistry of the cyanide ion........................................................... 32

Formation of gold cyanide.............................................................. 36

Tests for cyanide in some native and naturalized plants of the United

States, by Hansford T. Shacklette.

Solubilization of gold by microorganisms and organic substances, by

Kenneth G. Doxtader.................................................................... 47

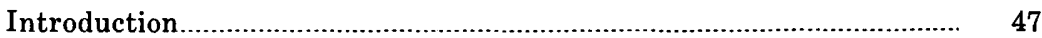

Gold substrate

Culture media

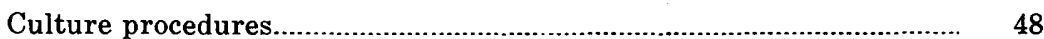

Analysis of the culture liquids for soluble gold.................................. 48

Results and discussion....................................................................... 49

Solubilization of gold by stock cultures of bacteria and fungi.... $\quad 49$

Solubilization of gold by microbial isolates from soil and sediments..

Solubilization of variantly prepared colloidal gold......................... 51

The action of peptone solutions on colloidal gold........................... 52

Isolation of soil microorganisms resistant to high concentrations of metallic ions.

Studies of the distribution of gold in soils and vegetation.........................

Preparation of samples....................................................................... 53

Ignition and ashing........................................................................ 54

Solution and estimation of gold......................................................... 54

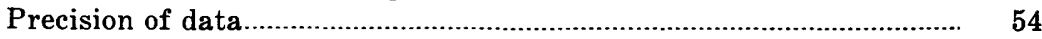


Studies of the distribution of gold in soils and vegetation - Continued

Studies of gold in soil profiles and vegetation.

Page

Mull as a sample medium in geochemical exploration for gold.

Summary of conclusions.

Literature cited

\section{ILLUSTRATIONS}

FIgURE 1. Diagram showing equilibrium distribution of unstable sulfur species in water

2. Map showing location of sites where plants were sampled for cyanide testing, and the vegetation type or types present at the sites

3. Diagram showing number of particles of gold at $1 \mathrm{ppm}$ in samples having different weights, and for a 1-g sample at $0.1 \mathrm{ppm}$.

4. Histograms of gold content of soil profiles and associated vegetation, showing high gold values near both the top and bottom of the profiles.

5. Histograms of gold content of soil profiles and associated vegetation, showing high gold values near the top of the profiles

6. Histograms of gold content of soil profiles and associated vegetation, showing high gold values near the bottom of the profiles

7. Sample locality map of the Empire district, Colorado, showing location of site EM-698.

8. Sample locality map showing relationship of detailed sampling around site EM-698 and reconnaissance sampling, Empire district, Colorado.

9. Geochemical and geologic map of locality EM-698 showing gold content of mull ash and vein material, Empire district, Colorado.

\section{TABLES}

TABLE 1. Standard electrode potentials at $25^{\circ} \mathrm{C}$.

2. Composition of solutions of gold complexes used in tests with minerals

3. Percentage of gold removed from solutions in contact with various minerals and rocks.

4. Removal, by minerals, of gold from solutions of various gold complexes.

5. Percentage of gold complex removed from solution by a 10 -gram powder sample of carbonaceous material.

6. Variation of gold absorption coefficients with three gold complexes for two species of Impatiens. 
TABLE 7. Solubilities of gold in hydrochloric acid

8. The interactions of the concentrations of $\mathrm{Cl}^{-1}, \mathrm{H}^{+1}$, and $\mathrm{MnO}_{2}$ on the solubility of gold in copper leach solutions...

9. Abundance of chlorine, bromine, and iodine and calculated relative abundance of bromine and iodine in various earth materials

10. The interactions of the concentrations of $\mathrm{Br}^{-1}, \mathrm{H}^{+1}$, and $\mathrm{MnO}_{2}$ on the solubility of gold in copper leach solutions......

11. The interactions of the concentrations of $\mathrm{I}^{-1}, \mathrm{H}^{+1}$, and $\mathrm{MnO}_{2}$ on the solubility of gold in copper leach solutions

12. Solubility of leaf gold in $0.05 M$ sodium iodide solutions adjusted to various $\mathrm{pH}$ values.

13. Solubility of ore gold in $0.05 M$ sodium iodide solutions adjusted to various $\mathrm{pH}$ values

14. Solubility of leaf gold in $0.0124 M$ sodium thiosulfate solutions adjusted to various $\mathrm{pH}$ values.

15. Solubility of ore gold in $0.0124 M$ sodium thiosulfate solution adjusted to various $\mathrm{pH}$ values.

16. Solubility of leaf gold in $0.1 \mathrm{M}$ potassium thiocyanate solutions adjusted to various $\mathrm{pH}$ values.

17. Solubility of ore gold in $0.1 M$ potassium thiocyanate solutions adjusted to various $\mathrm{pH}$ values.

18. The interactions of the concentration of $\mathrm{CNS}^{-1}$ and $\mathrm{H}^{+1}$ on the solubility of gold in copper leach solutions

19. Some cyanoglycosides, associated enzyme source, and hydrolysis products

20. Solution of leaf gold by native cyanogenic plants macerated in plant-water slurries

21. Solubility of gold in slurries of macerated peach roots, macerated peach roots plus emulsin, and in emulsin-water mixtures.

22. Approximate cyanide concentrations in solutions, as indicated by color reactions of picric acid paper suspended over the solutions

23. Results of tests for hydrocyanic acid ( $\mathrm{HCN})$ in selected species of plants.

24. Solubilization of colloidal gold by bacterial strains grown in glucose medium with yeast extract and with peptone..........

25. Gold solubilization by fungal strains grown in glucose-peptone medium

26. Effect of shaking flasks on microbial solubilization of gold.....

27. Gold solubilization by bacterial strains isolated from soil and sediment.

28. Effect of microbial strains on variantly prepared colloidal gold.

29. Solubilization of gold by components of glucose-peptone medium.

30. Precision of replicate analyses for gold in various materials

31. Comparison between gold content of soil and that of cobbles and pebbles. 
TABLE 32. Gold content of seven size fractions of soil horizons in six soil profiles

33. Gold content of the ash of various parts of lodgepole pine and aspen growing near gold-bearing vein 


\title{
GEOGHEMISTRY OF GOLD IN THE WEATHERING GYCLE
}

\author{
By Hubert W. Lakin, Gary C. Gurtin, and Arthur E. Hubert
}

\section{ABSTRACT}

Gold is mobile in the supergene environment under certain weathering conditions. The presence of gold in plant tissues has been reported by many investigators. Because colloidal gold is not taken up by plants, and because the simple ions $\mathrm{Au}^{+1}$ and $\mathrm{Au}^{+3}$ cannot exist in appreciable quantities in aqueous solutions, gold must enter the plant as a soluble complex ion. The enrichment of gold in forest humus mull and near-surface soil also suggests that the mobility of gold as a complex ion is transitory.

We have considered that the following complex ions possibly play a role in the migration of gold: $\mathrm{AuCl}_{4}^{-2}, \mathrm{AuBr}_{4}^{-1}, \mathrm{AuI}_{2}{ }^{-1}, \mathrm{Au}(\mathrm{CN})_{2}{ }^{-1}, \mathrm{Au}(\mathrm{CNS})_{4}^{-1}$, and $\mathrm{Au}\left(\mathrm{S}_{2} \mathrm{O}_{3}\right)_{2}{ }^{-3}$.

The following standard electrode potentials illustrate the marked dependence of the oxidation potential on the nature of the gold complex that is formed.

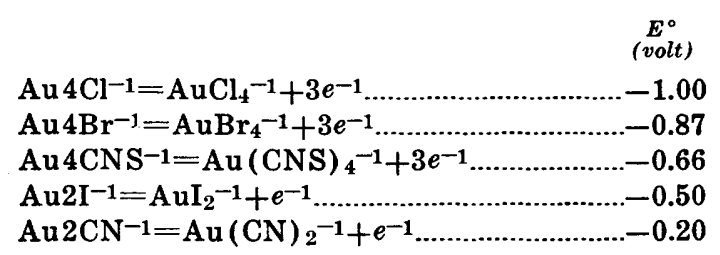

Electrode potential for the reaction $\mathrm{Au}+2 \mathrm{~S}_{2} \mathrm{O}_{3}-2=\mathrm{Au}\left(\mathrm{S}_{2} \mathrm{O}_{3}\right)_{2}^{-3}+e^{-1}$ is not available, but, because gold reacts with $\mathrm{Na}_{2} \mathrm{~S}_{2} \mathrm{O}_{3}$ in aerated water, the potential of the complex is probably near -0.6 or -0.7 volt.

Consequently, the oxidant and the $\mathrm{pH}$ required to oxidize gold change markedly. Thus, at a $\mathrm{pH}$ of 2 in a solution of $\mathrm{Fe}_{2}\left(\mathrm{SO}_{4}\right)_{3}$ and $\mathrm{CuSO}_{4}$ containing $0.05 M$ (molar) $\mathrm{Cl}^{-1}$, gold leaf is dissolved very slowly, if at all $\leqq 0.004 \mathrm{mg} / 1$ in 1 month; when $0.05 M^{-1}$ is used, $1.2 \mathrm{mg} / 1$ is dissolved in 1 month; but with $0.05 M \mathrm{I}^{-1}, 72 \mathrm{mg} / \mathrm{l}$ of gold is dissolved in 1 week. In contrast to the halide complexes, aqueous $0.05 M$ solutions of the sodium salts of $\mathrm{CN}^{-1}, \mathrm{CNS}^{-1}$, and $\mathrm{S}_{2} \mathrm{O}_{3}{ }^{-2}$ ( $\mathrm{pH} 5$ to 7 ) dissolve 14, 0.16, and $3.4 \mathrm{mg} / \mathrm{l}$, respectively, of leaf gold in 1 month, offering the possibility of solution of gold in soils.

In a carbonate-free environment, the oxidation of pyrite produces an acid solution suitable for the oxidation of gold by chloride if $\mathrm{MnO}_{2}$ is also present. Although the ease of oxidation of gold increases in the order $\mathrm{Cl}^{-1}, \mathrm{Br}^{-1}, \mathrm{I}^{-1}$, the abundance of these halides in the earth's crust decreases in the same order - their molecular abundance ratio in the crust is approximately 100 , 
$0.6,0.06$. In a carbonate environment, the oxidation of pyrite may produce sufficient $\mathrm{S}_{2} \mathrm{O}_{3}-2$ to dissolve gold.

In an oxidizing environment at $\mathrm{pH}$ of 5 to 8 , only $\mathrm{S}_{2} \mathrm{O}_{3}{ }^{-2}, \mathrm{CNS}^{-1}$, and $\mathrm{CN}^{-1}$ may be expected to dissolve gold. Thiosulfates are transient products of biological activity in soils but never reach substantial concentrations. Thiocyanates are even less abundant in soils. Cyanides are produced by the hydrolysis of cyanogenetic glycosides which are abundant. More than 1,000 species of plants yield $\mathrm{HCN}$ on hydrolysis; many arthropods produce $\mathrm{HCN}$; and some fungi also produce appreciable amounts of $\mathrm{HCN}$. Macerated aqueous suspensions of 16 species of native plants collected in Colorado, Utah, Nevada, and Arizona dissolved leaf gold.

The absorption of gold from solution by a given plant species is a function of the gold complex present. Gold chloride, thiocyanate, and thiosulfate are very weakly absorbed through the roots of Impatiens hostii; gold bromide and iodide are moderately absorbed (100 times more than the chloride).

In the microbiological studies, elemental gold was added to liquid nutrient media which were then inoculated with pure cultures of bacteria and fungi either obtained from stock collections or isolated from soil. In a glucosepeptone medium containing colloidal gold, significant gold solubilization occurred. In other media or with powdered gold, metal solubilization was slight. The microbial strains showed various abilities to solubilize the noble metal. In sterile glucose-peptone medium gold solubilization occurred, but, in the same medium inoculated with various microorganisms, the solubilization of gold increased.

The stability of the gold complex has a marked effect on the mobility of gold, as illustrated by the removal of gold from solution by various minerals. With radioactive gold as a tracer, 114 mineral powders were mixed for 1 minute with solutions, at $\mathrm{pH} 6$, of these six gold complexes and immediately centrifuged to obtain a clear supernatant liquid and a mineral centrifugate. The radioactivity of these separates was then measured to determine the amount of gold remaining in solution. Of the 114 minerals tested, the numbers of minerals removing 90 percent or more of the gold from solution were, respectively: 52 from gold chloride, 47 from gold bromide, 23 from gold iodide, 6 from gold cyanide, 4 from gold thiocyanate, and 3 from gold thiosulfate.

Acidic oxidation of pyritic gold deposits may result in transient mobilization of gold as $\mathrm{AuCl}_{+}^{-1}$. Alkaline oxidation of pyritic gold deposits may result in transient mobilization of gold as $\mathrm{Au}\left(\mathrm{S}_{2} \mathrm{O}_{3}\right)^{-3}$. In soils under native vegetation gold may be mobilized as $\mathrm{Au}(\mathrm{CN})_{2}{ }^{-1}$. Whatever the circumstances, the gold solutions would be transitory.

\section{INTRODUCTION}

\section{SCOPE OF REPORT}

Weathering is sometimes defined as the physical and chemical action on rocks in contact with the atmosphere. The physical action of frost in fracturing rocks and the abrasive action of wind and flowing water increase the surfaces exposed to the atmosphere without affecting the mineral composition of the rocks. Chemical weathering is defined by Loughman (1969) as follows: "Chemical weathering is a process by which atmospheric, hydrospheric and biologic agencies act upon and react with the mineral constituents 
of rocks within the zone of influence of the atmosphere, producing relatively more stable, new mineral species." In the process the sulfides, sulfosalts, and tellurides, with which gold is frequently associated, are oxidized, and gold commonly remains as, or is reduced to, the metallic state. The purpose of this study was to investigate some possible mechanisms of solution of metallic gold and its transport in solutions in the weathering or weathered environment.

The presence of gold in plants and of gold dissolved in stream waters and in the oceans indicates that some mechanisms for solution of gold do exist.

Relatively high values for the gold content of ocean water led Haber (1928) to believe that mining gold from the ocean might be a feasible way to pay the German war debts. Haber's 7-year study of gold in estuaries of German rivers and in the ocean was summarized by Jaenicke (1935). Gold has also been reported in stream waters (Gosling and others, 1971).

Gold was reported in plants more than a century ago by MalteBrun (1824, p. 221), who stated:

It is also proved by the experiments of Sage, Bertholler, Rouelle, Darcet and Deyeux, that there are particles of gold existing in vegetables. Bertholler has extracted about $2 \mathrm{~g}, 14 / 100(2.14 \mathrm{~g})$ or 40 grains $1 / 10$ of gold, from 489 hectogrammes, or a quintal of ashes. Werner assures us, that at Zalatna, native gold has been found in half petrified wood, or rather, says he, in bituminous wood.

The presence of gold in living plants and the enrichment of gold in the humus layer of the soil, as demonstrated by Goldschmidt (1937) and by Curtin, Lakin, Neuerburg, and Hubert (1968), suggest that gold is dissolved and transported in soil solutions and is taken up by plants. The summary by Jones (1970) of available data on the occurrence of gold in water, plants, and animals further substantiates the evidence that gold is mobilized in the weathering environment.

The major part of the present study was an evaluation of the stability of some possible gold complexes that might be the means of transport of gold in solution in oxidizing systems. For many years the effects of transport and supergene enrichment of gold have been observed in the oxidized zones of ore deposits (Spurr and Garrey, 1908, p. 149; Ransome, 1911, p. 169). Gold chloride ion $\left(\mathrm{AuCl}_{4}{ }^{-1}\right)$ traditionally has been considered to be the principal gold complex in solutions in the weathering environment. Brokaw (1910), after making a comparative study of different possible solvents of gold, concluded that mixtures of $\mathrm{Fe}\left(\mathrm{SO}_{4}\right)_{3}, \mathrm{H}_{2} \mathrm{SO}_{4}$, and $\mathrm{NaCl}$ in concentrations common in mine waters will readily dissolve 
gold to form gold chloride in the presence of manganese dioxide. This process has been demonstrated by other investigators, including Emmons (1917), Krauskopf (1951), and Cloke and Kelly (1964).

The formation and stability of the gold chloride complex in nature are restricted to very special conditions in which the acidity and chloride concentration must be high and in which manganese dioxide must be present. These conditions are found only in some oxidizing sulfide ore deposits. The gold chloride complex is not formed, nor does it remain stable, in near-neutral solutions with a relatively low chloride content that characterizes ground water and water in streams and lakes. As an example, gold precipitated readily from a neutral solution of gold chloride when it was placed in contact with onion roots (Shacklette and others, 1970). The experiment demonstrated that gold complexes other than gold chloride are required for the migration of gold into plants and in streams and ground water.

Results of our studies show that gold cyanide and thiocyanate may be the most common stable gold complexes in soils, plants, and natural waters. Cyanide and thiocyanate ions are products of hydrolysis of plant glycocides by enzymatic action (Armstrong and Armstrong, 1931, p. 67; Timonin, 1941, p. 404; Kingsbury, 1964, p. 23-27). These ions have the ability to complex gold in moderately oxidizing environments (Jacobson, 1949, p. 554 ; Manskaya and Drozdova, 1968, p. 271). The gold cyanide and thiocyanate ions remain in solution when in contact with common rocks and minerals, and they are readily taken up by plants. The other ions studied-chloride, bromide, iodide, and thiosulfate-may form complexes with gold which remain stable only long enough to permit some restricted movement of gold under special conditions.

\section{ACKNOWLEDGMENTS}

We acknowledge the aid given us by several U.S. Geological Survey personnel. Charles W. Gale III aided us in field and laboratory studies and added to our knowledge of gold iodide systems by his investigation of the stability of the gold iodide complex in a strong oxidizing environment. Hansford T. Shacklette aided greatly by his identification of native plants and his joint laboratory work on uptake of gold by plants. We thank F. O. Simon for the determination of gold in cement copper.

\section{OXIDATION POTENTIAL FOR GOLD AS A FUNCTION OF COMPLEX STABILITY}

Cotton and Wilkinson (1962, p. 867) introduced their discussion of gold compounds with the statement that the chemistry of gold 
is essentially a chemistry of complex compounds and that no simple gold cations exist in aqueous solution. This concept is very important in understanding the behavior of gold. To illustrate, gold may be in contact with oxygenated water, such as a mountain stream, for a millennium without dissolving, but if $250 \mathrm{ppm}$ (parts per million) of cyanide ion is added to this water, the gold is readily dissolved. The cyanide ion is not an oxidant but forms a complex with the gold. In its presence, the oxidation potential for gold (table 1) is reduced from -1.50 to -0.20 volts and the dissolved oxygen in the water becomes a sufficiently strong oxidant to dissolve the gold.

The standard electrode potentials for the oxidation of gold in the presence of a number of anions that form stable complexes with gold are given in table 1 . None of the ions which react with gold in these half cells is an oxidant of gold. The difference in the strength of the oxidant (indicated by the electrode potential) required to oxidize gold lies in the strength of the gold complex formed with the indicated anion.

Gold is oxidized by $\mathrm{MnO}_{2}$ in acid chloride solutions. Krauskopf (1951, p. 863) emphasized that the purpose of the chloride ion is to form a very stable complex ion with the dissolved gold. Gold is not oxidized appreciably in acid $(\mathrm{pH} 2)$ ferric and cupric sulfate solutions containing chloride ions in the absence of $\mathrm{MnO}_{2}$. Gold is slowly oxidized in the same acid sulfate solutions containing bromide ions, and it is rapidly oxidized in the acid sulfate solution containing iodide ions. This sequence illustrates the increasing ease of oxidation of gold with increasing strength of the complex ion.

TABLE 1. - Standard electrode potentials at $25^{\circ} \mathrm{C}$

[From Latimer (1952)]

\begin{tabular}{|c|c|}
\hline In acid solution & $E^{\circ}$ (volts) \\
\hline $\mathrm{Au}=\mathrm{Au}^{+3}+3 e^{-1} \ldots \ldots \ldots \ldots \ldots \ldots$ & -1.50 \\
\hline $\mathrm{Au}+4 \mathrm{Cl}^{-1}=\mathrm{AuCl}_{4}{ }^{-1}+3 e^{-1} \ldots \ldots \ldots \ldots \ldots \ldots$ & -1.00 \\
\hline $\mathrm{Au}+4 \mathrm{Br}^{-1}=\mathrm{AuBr}_{4}{ }^{-1}+3 e^{-1}$ & -0.87 \\
\hline $\mathrm{Au}+4 \mathrm{CNS}^{-1}=\mathrm{Au}(\mathrm{CNS})_{4}^{-1}+3 e^{-1}$ & -0.66 \\
\hline \multicolumn{2}{|c|}{ About -1.68} \\
\hline $\mathrm{Au}+\mathrm{Cl}^{-1}=\mathrm{AuCl}+e^{-1} \ldots \ldots \ldots \ldots \ldots$ & -1.17 \\
\hline $\mathrm{Au}+2 \mathrm{Br}^{-1}=\mathrm{AuBr}_{2} 2^{-1}+e^{-1}$ & -0.96 \\
\hline $\mathrm{Au}+2 \mathrm{CNS}-1=\mathrm{Au}(\mathrm{CNS}) 2_{2}^{-1}+e^{-1} \ldots \ldots$ & -0.69 \\
\hline $\mathrm{Au}+\mathrm{I}^{-1}=\mathrm{AuI}+e^{-1}$ & -0.50 \\
\hline In basic solution & $E^{\circ}$ (volts) \\
\hline $\mathrm{Au}+2 \mathrm{CN}^{-1}=\mathrm{Au}(\mathrm{CN})_{2}+e^{-1}$ & $1-0.20$ \\
\hline
\end{tabular}

1 Value from Charlot (1954, p. 249). 
It is interesting to note in table 1 that the larger negative potentials of $\mathrm{AuCl}, \mathrm{AuBr}_{2}{ }^{-1}$, and $\mathrm{Au}(\mathrm{CNS})_{2}{ }^{-1}$ than those for the corresponding trivalent complexes indicate that the univalent gold complexes are unstable. If the univalent gold complexes are formed, they would disproportionate to yield $2 \mathrm{Au}^{\circ}+\mathrm{Au}^{+3}$ complex.

\section{REMOVAL OF GOLD FROM SOLUTION BY MINERALS}

\section{AS A FUNCTION OF COMPLEX STABILITY .}

One measure of the stability of a gold complex is given by its mobility in a geologic environment. In the literature on the downward migration of gold in oxidizing ore bodies, the gold is presumed to be moving as gold chloride. Laboratory experiments with gold chloride solutions (Clarke, 1924, p. 662) have shown that many sulfides, carbonaceous materials, and carbonates precipitate gold. Pyrite is especially effective in the precipitation of gold. Skey $(1873$, p. 380$)$ calculated that the 152-pound "Welcome Nugget" of Australia could have grown by precipitation of gold on the face of a 12-pound chunk of pyrite. Emmons (1917, p. 324) concluded that the presence of alkali minerals that neutralize the acid solutions formed by oxidation of pyrite would inhibit the movement of gold as a chloride. In favorable conditions, such as existed at Creede, Colo., Emmons (1917, p. 314) found gold enrichment at depths of 200-700 feet below the surface.

A qualitative comparison was made of the effect of $114 \mathrm{~min}$ erals, rocks, and miscellaneous materials on solutions of radioactive gold chloride, bromide, iodide, cyanide, thiocyanate, and thiosulfate to supplement the voluminous literature on the effect of various minerals on chloride solutions of gold.

Aqueous solutions were prepared with the composition shown in table 2. The lower gold contents of the thiocyanate and thiosulfate solutions are due to the slow rate of solution of gold in

TABLE 2. - Composition of solutions of gold complexes used in tests with minerals

\begin{tabular}{|c|c|c|c|c|}
\hline \multicolumn{3}{|c|}{ Complexing ion } & \multirow{2}{*}{$\begin{array}{l}\text { Gold in } \\
\text { solution } \\
(\text { ppm })\end{array}$} & \multirow{2}{*}{$\begin{array}{c}\text { pH of } \\
\text { solution }\end{array}$} \\
\hline Ion & $\begin{array}{c}\text { Concentration } \\
(M)\end{array}$ & Source & & \\
\hline Chloride & 0.1 & $\mathrm{HCl}$ & 18 & 6 \\
\hline Bromide................ & $\ldots \ldots .1$ & $\mathrm{HBr}$ & 11 & 6 \\
\hline Iodide & .......... 08 & $\mathrm{HI}$ & 11 & 6 \\
\hline Cyanide............... & ….... 002 & $\mathrm{NaCN}$ & 11 & 6 \\
\hline Do.................... & ........ .002 & $\mathrm{NaCN}$ & 12 & 8 \\
\hline Thiocyanate...... & .025 & $\mathrm{NaCNS}$ & .15 & 6 \\
\hline Thiosulfate...... & ........ 008 & $\mathrm{Na}_{2} \mathrm{~S}_{2} \mathrm{O}_{3}$ & 3 & 6 \\
\hline
\end{tabular}

${ }^{1}$ At the beginning of the tests each solution contained 2 mc (microcuries) $\mathrm{Au}^{198}$ per liter. ${ }^{2} \mathrm{pH}$ of the halogen solutions was adjusted with sodium hydroxide, and $\mathrm{pH}$ of the remaining solutions, with dilute sulfuric acid. 
the sodium salts of these ions. All the solutions contained the same concentration of radioactive gold, and this concentration dropped drastically with time; therefore, the last measurements were made two half-lives later than the first ones.

The minerals used in the experiment are listed in table 3 with the data obtained. The listed mineral was the major component but was rarely a pure specimen. They were ground to a fine powder $(<0.1 \mathrm{~mm})$ in a ball mill but were not sized. Thus, the total surface of one mineral specimen may be markedly different from that of another. This variation is a serious factor in evaluating the data, and, because of it and the lack of purity of the mineral specimens, the data could be considered only qualitative.

One gram of each mineral powder was placed in a test tube with $10 \mathrm{ml}$ (milliliters) of each solution. They were shaken for about 30 seconds, until the powder was dispersed in the aqueous solution. After the contents of the test tubes had been mixed, they were centrifuged to separate the mineral powder as a residue in the bottom of the tube. The supernatant liquid was decanted into another test tube. The radioactivity of both the mineral centrifugate and the supernatant liquid portions were measured by a scintillation counter using a well-type 1.5-inch thallium-activated sodium iodide crystal detector. Only the measurements obtained with the aqueous phase were used if the mineral was naturally radioactive.

The data summarized in table 4 show marked loss of gold from the halide solutions for many minerals, in contrast to that of the cyanide, thiocyanate, and thiosulfate solutions. Thus, $20-45$ percent of the minerals remove 90 percent or more of the gold from solutions of the halide complexes, whereas only about 5 percent or less of the minerals remove 90 percent of the gold from solutions of the cyanide, thiocyanate, and thiosulfate complexes.

One cannot determine from these data whether the gold complex is sorbed by the mineral or whether the gold is reduced to the metal. Reduction is suggested, however, by the gross relationship of removal of gold from solution to the oxidation potential for the complex. To illustrate, the standard electrode potentials for $\mathrm{AuCl}_{4}{ }^{-1}, \mathrm{AuBr}_{4}{ }^{-1}$, and $\mathrm{AuI}_{2}{ }^{-1}$ are $-1.00,-0.87$, and -0.50, and the percentages of the minerals removing 90 percent or more of the gold from solution are 46, 41, and 20, respectively.

Carbonaceous materials are often associated with gold, as at the Getchell, Carlin, Cortez, and Gold Acres mines in Nevada, and gold is difficult to recover from such unoxidized ores.

In order to observe the relative stability of various gold complexes in the presence of carbonaceous material, $10 \mathrm{~g}$ (grams) of 
TABLE 3. - Percent gold removed from solutions in contact with various minerals and rocks

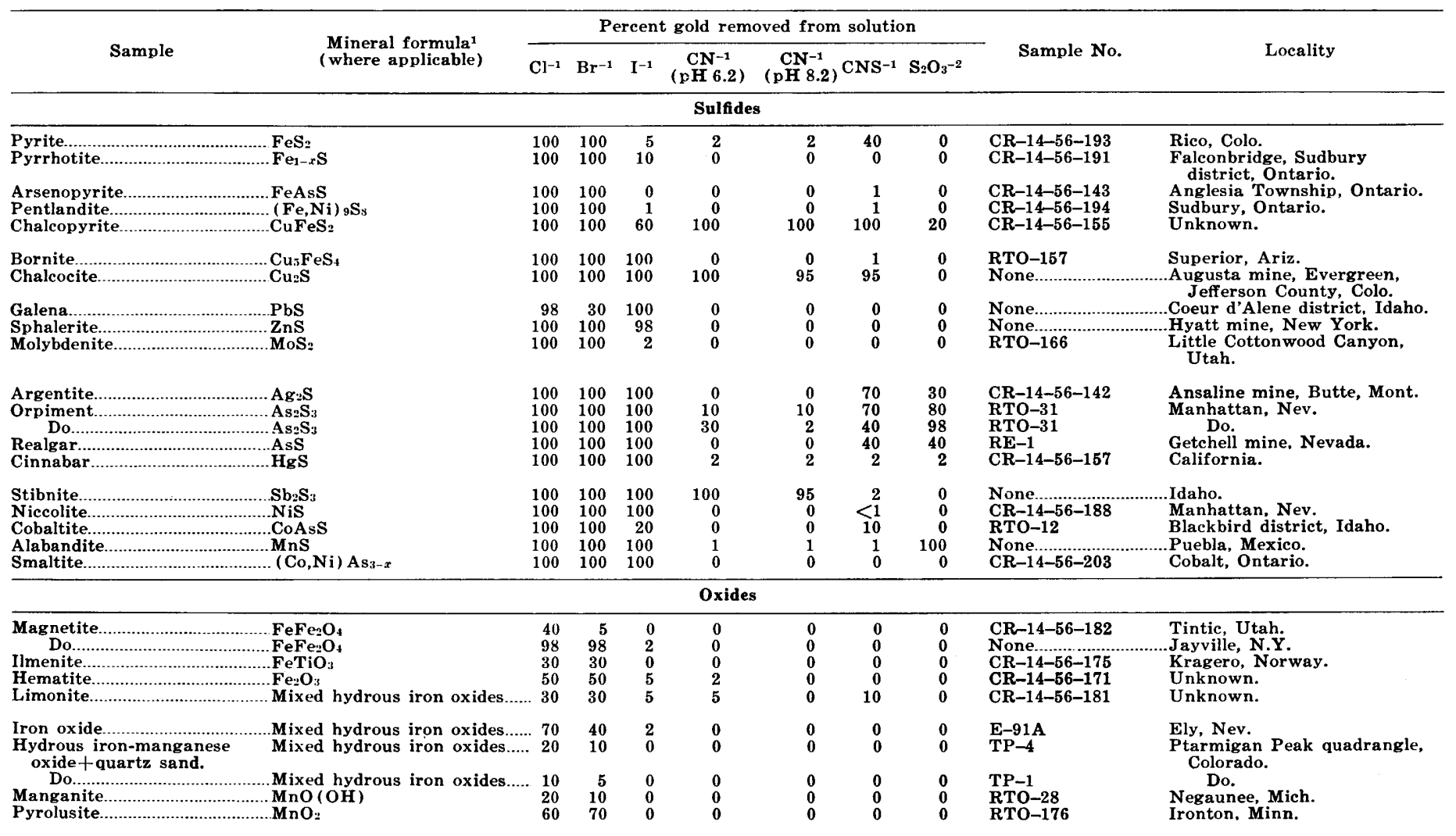




\begin{tabular}{|c|c|c|c|c|c|c|c|c|c|}
\hline $\begin{array}{l}\text { Cryptomelane } \\
\text { Hollandite }\end{array}$ & 40 & 40 & 2 & 0 & 0 & 0 & $\mathbf{0}$ & RTO-159 & India. \\
\hline $\begin{array}{l}\text { Hausmannite } \\
\text { Franklinite } \\
\text { Cuprite. }\end{array}$ & $\begin{array}{r}85 \\
90 \\
100\end{array}$ & $\begin{array}{r}80 \\
100 \\
100\end{array}$ & $\begin{array}{r}0 \\
1 \\
100\end{array}$ & $\begin{array}{l}0 \\
0 \\
0\end{array}$ & $\begin{array}{l}0 \\
0 \\
0\end{array}$ & $\begin{array}{r}0 \\
0 \\
25\end{array}$ & $\begin{array}{l}\mathbf{0} \\
0 \\
1\end{array}$ & $\begin{array}{l}\text { RTO-22 } \\
\text { RTO-297 } \\
\text { RTO-15 }\end{array}$ & $\begin{array}{l}\text { Langban, Sweden. } \\
\text { Franklin Furnace, N.J. } \\
\text { He!ena, Mont. }\end{array}$ \\
\hline 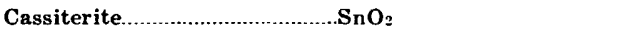 & 35 & 50 & 20 & 0 & 0 & 0 & 0 & CR-14-56-153 & Taylor Creek district, \\
\hline $\begin{array}{l}\text { Cervantite } \\
\text { Chromite } \\
\text { Rutile } \\
\text { Brucite }\end{array}$ & $\begin{array}{r}20 \\
10 \\
40 \\
7\end{array}$ & $\begin{array}{r}5 \\
15 \\
30 \\
15\end{array}$ & $\begin{array}{l}0 \\
1 \\
1 \\
4\end{array}$ & $\begin{array}{l}0 \\
0 \\
1 \\
1\end{array}$ & $\begin{array}{l}\mathbf{0} \\
0 \\
\mathbf{0} \\
\mathbf{1}\end{array}$ & $\begin{array}{l}0 \\
0 \\
0 \\
1\end{array}$ & $\begin{array}{r}\mathbf{0} \\
\mathbf{0} \\
\mathbf{0} \\
\mathbf{6 0}\end{array}$ & $\begin{array}{l}\text { CR-14-56-154 } \\
\text { CR-14-56-158 } \\
\text { CR-14-56-196 } \\
\text { CR-14-56-150 }\end{array}$ & $\begin{array}{l}\text { Mexico. } \\
\text { Selukew, Southern Rhodesia. } \\
\text { Nelson County, Va. } \\
\text { Luning, Nev. }\end{array}$ \\
\hline 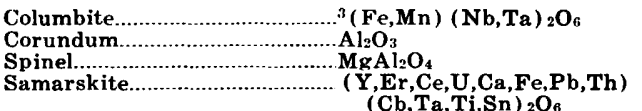 & $\begin{array}{r}30 \\
5 \\
100 \\
100\end{array}$ & $\begin{array}{l}30 \\
10 \\
99 \\
\mathbf{5 0}\end{array}$ & $\begin{array}{r}5 \\
3 \\
20 \\
0\end{array}$ & $\begin{array}{l}\mathbf{0} \\
\mathbf{0} \\
\mathbf{0} \\
\mathbf{0}\end{array}$ & $\begin{array}{l}\mathbf{0} \\
\mathbf{0} \\
\mathbf{0} \\
\mathbf{0}\end{array}$ & $\begin{array}{l}\mathbf{0} \\
0 \\
0 \\
0\end{array}$ & $\begin{array}{r}1 \\
0 \\
100 \\
0\end{array}$ & $\begin{array}{l}\text { CR-14-56-160 } \\
\text { CR-14-56-161 } \\
\text { CR-14-56-197 } \\
\text { CR-14-56-200 }\end{array}$ & $\begin{array}{l}\text { Quadville, Ontario. } \\
\text { Zoutpansberg, Transvaal. } \\
\text { Black Lake, Quebec. } \\
\text { Mitchell County, N.C. }\end{array}$ \\
\hline $\begin{array}{l}\text { Braunite } \\
\text { Psilomelane }\end{array}$ & $\begin{array}{r}100 \\
30\end{array}$ & $\begin{array}{r}100 \\
2\end{array}$ & $\begin{array}{l}1 \\
0\end{array}$ & $\begin{array}{l}0 \\
0\end{array}$ & $\begin{array}{l}0 \\
0\end{array}$ & $\begin{array}{l}0 \\
0\end{array}$ & $\stackrel{0}{0}$ & $\begin{array}{l}\text { RTO-197 } \\
\text { CR-14-56-190 }\end{array}$ & $\begin{array}{l}\text { Kyushu, Japan. } \\
\text { No. Mountain mine, Arkansas. }\end{array}$ \\
\hline \multicolumn{10}{|c|}{ Silicates, except clays ${ }^{4}$} \\
\hline 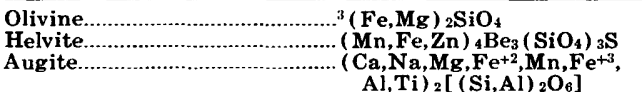 & $\begin{array}{l}60 \\
10 \\
90\end{array}$ & $\begin{array}{l}40 \\
20 \\
95\end{array}$ & $\begin{array}{l}1 \\
0 \\
0\end{array}$ & $\begin{array}{l}0 \\
0 \\
0\end{array}$ & $\begin{array}{l}\mathbf{0} \\
\mathbf{0} \\
\mathbf{0}\end{array}$ & $\begin{array}{l}0 \\
0 \\
0\end{array}$ & $\begin{array}{l}\mathbf{0} \\
\mathbf{0} \\
\mathbf{0}\end{array}$ & $\begin{array}{l}15 \\
\text { CR-14-56-180 } \\
\text { CR-14-56-146 }\end{array}$ & $\begin{array}{l}\text { Jackson County, N.C. } \\
\text { Iron Mountain, New Mexico. } \\
\text { Otter Lake, Quebec. }\end{array}$ \\
\hline 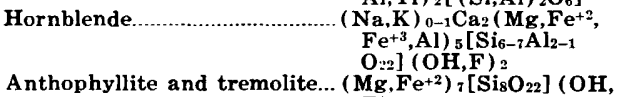 & 100 & 100 & 1 & 1 & 1 & $\mathbf{0}$ & $\mathbf{0}$ & 24 & Faraday Township, Ontario. \\
\hline $\begin{array}{c}\mathrm{F})_{2} \\
\mathrm{Ca}_{2}\left(\mathrm{Mgg}, \mathrm{Fe}^{+2}\right)_{5}\left[\mathrm{Sis}_{22}\right] \\
(\mathrm{OH}, \mathrm{F})_{2}\end{array}$ & 100 & 100 & 1 & $\mathbf{0}$ & $\mathbf{0}$ & $\mathbf{0}$ & 0 & 25 & Fullerville, N.Y. \\
\hline 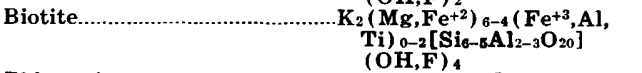 & 80 & 60 & 10 & 0 & - & $<10$ & $\mathbf{0}$ & CR-14-56-149 & New Hampshire. \\
\hline $\begin{array}{c}\text { Phlogopite } \\
\left.(\mathrm{OH}, \mathrm{F})_{4}\right)_{6}\left[\mathrm{Ki}_{6} \mathrm{Kl}_{2} \mathrm{O}_{20}\right]\end{array}$ & 100 & 98 & 3 & 2 & 2 & $\mathbf{2}$ & 2 & 27 & North Burgess, Ontario. \\
\hline 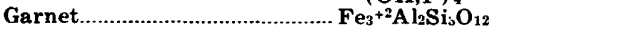 & 60 & 15 & $\mathbf{0}$ & $\mathbf{0}$ & $\mathbf{0}$ & $\mathbf{0}$ & $\mathbf{0}$ & CR-14-56-145 & $\begin{array}{l}\text { Gore Mountain, Warren } \\
\text { County, N.Y. }\end{array}$ \\
\hline $\begin{array}{l}\text { Allanite. } \\
\left.\qquad \mathrm{Al}_{2} \mathrm{O}-\mathrm{Ce}\right)_{2}\left(\mathrm{Fe}^{+2}, \mathrm{Fe}^{+3} \mathrm{Si}_{2} \mathrm{O}_{7}\right]\left[\mathrm{SiO}_{4}\right]\end{array}$ & 98 & 99 & 98 & $\mathbf{0}$ & $\mathbf{0}$ & $\mathbf{5}$ & 10 & CR-14-56-138 & $\begin{array}{l}\text { Pecoema Canyon near } \\
\text { Los Angeles, Calif. }\end{array}$ \\
\hline 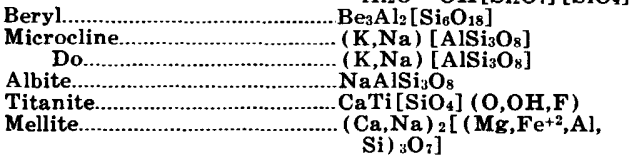 & $\begin{array}{l}40 \\
20 \\
2 \\
95 \\
80 \\
10\end{array}$ & $\begin{array}{r}5 \\
30 \\
1 \\
95 \\
60 \\
5\end{array}$ & $\begin{array}{r}\mathbf{0} \\
\mathbf{0} \\
0 \\
\mathbf{3 0} \\
\mathbf{0} \\
\mathbf{0}\end{array}$ & $\begin{array}{l}0 \\
0 \\
0 \\
2 \\
0 \\
0\end{array}$ & $\begin{array}{l}\mathbf{0} \\
\mathbf{0} \\
\mathbf{0} \\
\mathbf{2} \\
0 \\
0\end{array}$ & $\begin{array}{l}0 \\
1 \\
0 \\
2 \\
0 \\
0\end{array}$ & $\begin{array}{l}0 \\
0 \\
0 \\
0 \\
0 \\
0\end{array}$ & $\begin{array}{l}\text { CR-14-56-148 } \\
\text { CR-14-56-186 } \\
\text { CR-14-56-186 } \\
\text { CR-14-56-137 } \\
\text { CR-14-56-201 } \\
4\end{array}$ & $\begin{array}{l}\text { Keystone, S. Dak. } \\
\text { Perry Sound district, Ontario. } \\
\text { Do. } \\
\text { Amelia Court House, Va. } \\
\text { Westport, Ontario. } \\
\text { Unknown. }\end{array}$ \\
\hline
\end{tabular}


TABLE 3. - Percent gold removed from solutions in contact with various minerals and rocks - Continued

\begin{tabular}{|c|c|c|c|c|c|c|c|c|c|}
\hline \multirow[b]{2}{*}{$\begin{array}{l}\text { Mineral formula } \\
\text { (where applicable) }\end{array}$} & \multicolumn{7}{|c|}{ Percent gold removed from solution } & \multirow[b]{2}{*}{ Sample No. } & \multirow[b]{2}{*}{ Locality } \\
\hline & $\mathrm{Cl}^{-1}$ & $\mathbf{B r}^{-1}$ & $I^{-1}$ & $\begin{array}{c}\mathrm{CN}^{-1} \\
(\mathrm{pH} 6.2)\end{array}$ & $\begin{array}{c}\mathrm{CN}^{-1} \\
(\mathrm{pH} 8.2)\end{array}$ & $\mathrm{CNS}^{-1}$ & $\mathrm{~S}_{2} \mathrm{O}_{3}-2$ & & \\
\hline \multicolumn{10}{|c|}{ Silicates, except clays ${ }^{4}-$ Continued } \\
\hline $\begin{array}{l}\text { Nepheline } \\
\text { Scapolite } \\
\mathrm{Na}_{3}(\mathrm{Na}, \mathrm{K})\left[\mathrm{Al}_{4} \mathrm{Si}_{4} \mathrm{O}_{16}\right] \\
\left(\mathrm{Na}_{16} \mathrm{Ca}, \mathrm{K}\right)_{4}\left[\mathrm{Al}_{3}\left(\mathrm{Al}_{1, \mathrm{Si}}\right)_{3}\right. \\
\left.\mathrm{Si}_{6} \mathrm{O}_{24}\right]\left(\mathrm{Cl}_{1}, \mathrm{CO}_{3}, \mathrm{SO}_{4}, \mathrm{OH}\right)\end{array}$ & $\begin{array}{l}40 \\
10\end{array}$ & $\begin{array}{l}40 \\
30\end{array}$ & $\begin{array}{l}\mathbf{0} \\
\mathbf{0}\end{array}$ & $\begin{array}{l}\mathbf{0} \\
\mathbf{0}\end{array}$ & $\begin{array}{l}\mathbf{0} \\
\mathbf{0}\end{array}$ & $\begin{array}{l}0 \\
0\end{array}$ & $\begin{array}{l}0 \\
0\end{array}$ & $\begin{array}{l}7 \\
8\end{array}$ & $\begin{array}{l}\text { Bancroft, Ontario. } \\
\text { Templeton, Quebec. }\end{array}$ \\
\hline $\begin{array}{l}\text { Wollastonite } \\
\text { Lepidolite } \\
\left.\mathrm{O}_{20}\right](\mathrm{OH}, \mathrm{F})_{4}\end{array}$ & $\begin{array}{r}30 \\
1\end{array}$ & $\begin{array}{l}10 \\
20\end{array}$ & $\begin{array}{l}2 \\
1\end{array}$ & $\begin{array}{l}1 \\
0\end{array}$ & $\begin{array}{l}1 \\
0\end{array}$ & $\begin{array}{l}0 \\
0\end{array}$ & $\begin{array}{l}\mathbf{0} \\
0\end{array}$ & $\begin{array}{l}32 \\
\text { CR-14-56-179 }\end{array}$ & $\begin{array}{l}\text { Willsboro, N.Y. } \\
\text { Karibib, S.W. Africa. }\end{array}$ \\
\hline 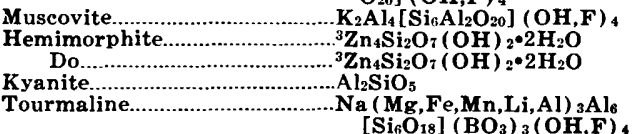 & $\begin{array}{r}60 \\
100 \\
50 \\
80 \\
50\end{array}$ & $\begin{array}{r}20 \\
100 \\
50 \\
40 \\
60\end{array}$ & $\begin{array}{r}10 \\
1 \\
30 \\
3 \\
40\end{array}$ & $\begin{array}{l}0 \\
1 \\
0 \\
1\end{array}$ & $\begin{array}{l}-1 \\
0 \\
1 \\
0\end{array}$ & $\begin{array}{l}\mathbf{0} \\
\mathbf{1} \\
\mathbf{0} \\
\mathbf{0} \\
\mathbf{0}\end{array}$ & $\begin{array}{l}\mathbf{0} \\
\mathbf{1} \\
\mathbf{0} \\
\mathbf{0} \\
\mathbf{0}\end{array}$ & $\begin{array}{l}\text { CR-14-56-187 } \\
\text { CR-14-56-172 } \\
\text { CR-14-56-173 } \\
\text { CR-14-56-177 } \\
\text { CR-14-56-207 }\end{array}$ & $\begin{array}{l}\text { Pinal County, Ariz. } \\
\text { Wentworth, Miss. } \\
\text { Brasstown, N.C. } \\
\text { San Diego, Calif. }\end{array}$ \\
\hline Dumortierite $\ldots \ldots \ldots \mathrm{Al}_{7},\left(\mathrm{BO}_{3}\right)\left(\mathrm{SiO}_{4}\right)_{3} \mathrm{O}_{3}$ & 20 & 10 & $\mathbf{0}$ & 0 & 0 & 0 & 0 & CR-14-56-162 & $\begin{array}{l}\text { Oreana, Pershing County, } \\
\text { Nev. }\end{array}$ \\
\hline 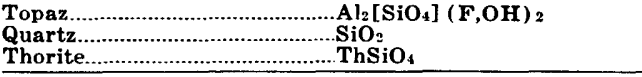 & $\begin{array}{r}1 \\
40 \\
40\end{array}$ & $\begin{array}{r}0 \\
20 \\
20 \\
\end{array}$ & $\begin{array}{l}\mathbf{0} \\
\mathbf{0} \\
\mathbf{0}\end{array}$ & $\begin{array}{l}\mathbf{0} \\
\mathbf{0} \\
\mathbf{0}\end{array}$ & $\begin{array}{l}\mathbf{0} \\
\mathbf{0} \\
\mathbf{0}\end{array}$ & $\begin{array}{l}\mathbf{0} \\
\mathbf{1} \\
\mathbf{0}\end{array}$ & $\begin{array}{l}\mathbf{0} \\
\mathbf{0} \\
\mathbf{0}\end{array}$ & $\begin{array}{l}12 \\
\text { None } \\
\text { CR-14-56-205 }\end{array}$ & $\begin{array}{l}\text { Jefferson County, s.C. } \\
\text { Unknown. } \\
\text { Do. }\end{array}$ \\
\hline \multicolumn{10}{|c|}{ Sulfosalts } \\
\hline Tetrahedrite. & 100 & 100 & 80 & 100 & 100 & 80 & 0 & RTO-305 & Coeur d'Alene district, Idaho. \\
\hline \multicolumn{10}{|c|}{ Sulfates } \\
\hline $\begin{array}{l}\text { Jarosite } \\
\text { Gypsum } \\
\text { Anglesite } \\
\text { Barite }\end{array}$ & $\begin{array}{r}30 \\
30 \\
1\end{array}$ & $\begin{array}{r}\mathbf{5 0} \\
\mathbf{3 0} \\
\mathbf{0}\end{array}$ & $\begin{array}{r}2 \\
70 \\
0\end{array}$ & $\begin{array}{l}\mathbf{1} \\
\mathbf{0} \\
\mathbf{0}\end{array}$ & $\begin{array}{l}1 \\
0 \\
0\end{array}$ & $\begin{array}{l}\mathbf{1} \\
\mathbf{2} \\
\mathbf{0}\end{array}$ & $\begin{array}{l}\mathbf{0} \\
\mathbf{0} \\
\mathbf{0}\end{array}$ & $\begin{array}{l}\text { None } \\
\text { CR-14-56-139........... } \\
\text { CR-14-56-147 }\end{array}$ & $\begin{array}{l}\text { San Bernardino, Calif. north } \\
\text { of Barstow. } \\
\text { Unknown. } \\
\text { Danville, } \mathbf{K y} \text {. }\end{array}$ \\
\hline \multicolumn{10}{|c|}{ Elements } \\
\hline 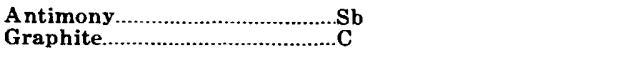 & $\begin{array}{l}100 \\
100\end{array}$ & $\begin{array}{l}100 \\
100\end{array}$ & $\begin{array}{l}100 \\
100\end{array}$ & $\begin{array}{r}\mathbf{0} \\
\mathbf{6 0}\end{array}$ & $\stackrel{0}{50}$ & $\begin{array}{l}75 \\
40\end{array}$ & $\begin{array}{l}\mathbf{2} \\
\mathbf{5}\end{array}$ & $\begin{array}{l}\text { CR-14-56-140 } \\
\text { RTO-21 }\end{array}$ & $\begin{array}{l}\text { Kern County, Calif. } \\
\text { Near Dillon, Mont. }\end{array}$ \\
\hline \multicolumn{10}{|c|}{ Carbonates } \\
\hline $\begin{array}{l}\text { Azurite } \\
\text { Calcite } \\
\text { Hydrozincite } \\
\text { Dolomite }\end{array}$ & $\begin{array}{r}100 \\
2 \\
90 \\
95\end{array}$ & $\begin{array}{r}100 \\
50 \\
10 \\
95\end{array}$ & $\begin{array}{r}\mathbf{5 0} \\
\mathbf{1} \\
\mathbf{2} \\
\mathbf{2}\end{array}$ & $\begin{array}{r}100 \\
0 \\
2 \\
1\end{array}$ & $\begin{array}{r}99 \\
2 \\
2 \\
0\end{array}$ & $\begin{array}{l}\mathbf{2} \\
\mathbf{0} \\
\mathbf{2} \\
\mathbf{1}\end{array}$ & $\begin{array}{l}\mathbf{0} \\
\mathbf{0} \\
\mathbf{0} \\
\mathbf{0}\end{array}$ & $\begin{array}{l}\text { CR-14-56-144 } \\
\text { CR-14-56-151 } \\
\text { CR-14-56-174 } \\
\text { CR-14-56-164-165 }\end{array}$ & $\begin{array}{l}\text { Grant County, N. Mex. } \\
\text { Cherokee County, S. Dak. } \\
\text { Dragoon, Ariz. } \\
\text { Thorn wood, N.Y. }\end{array}$ \\
\hline
\end{tabular}




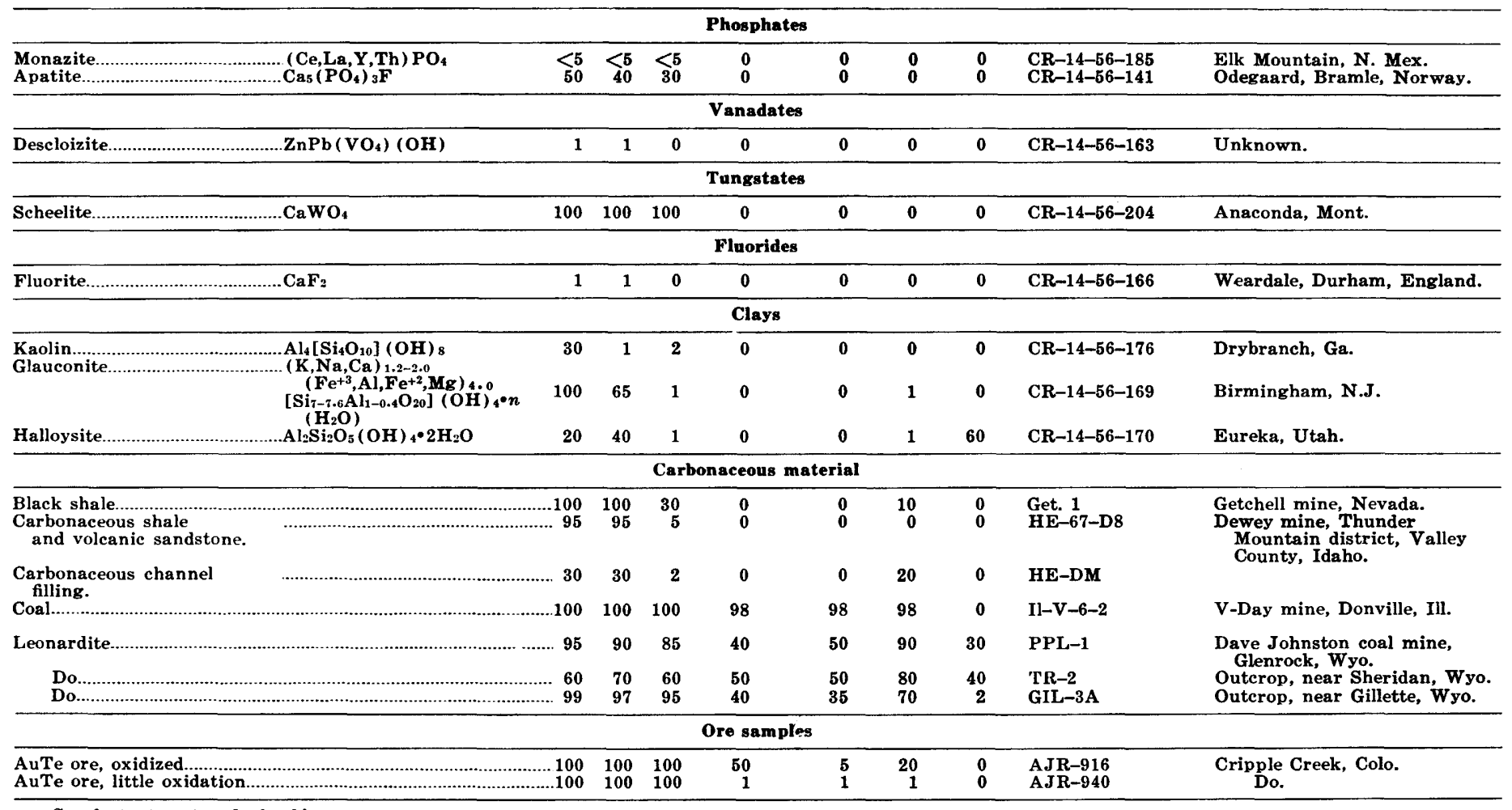

See footnotes at end of table. 


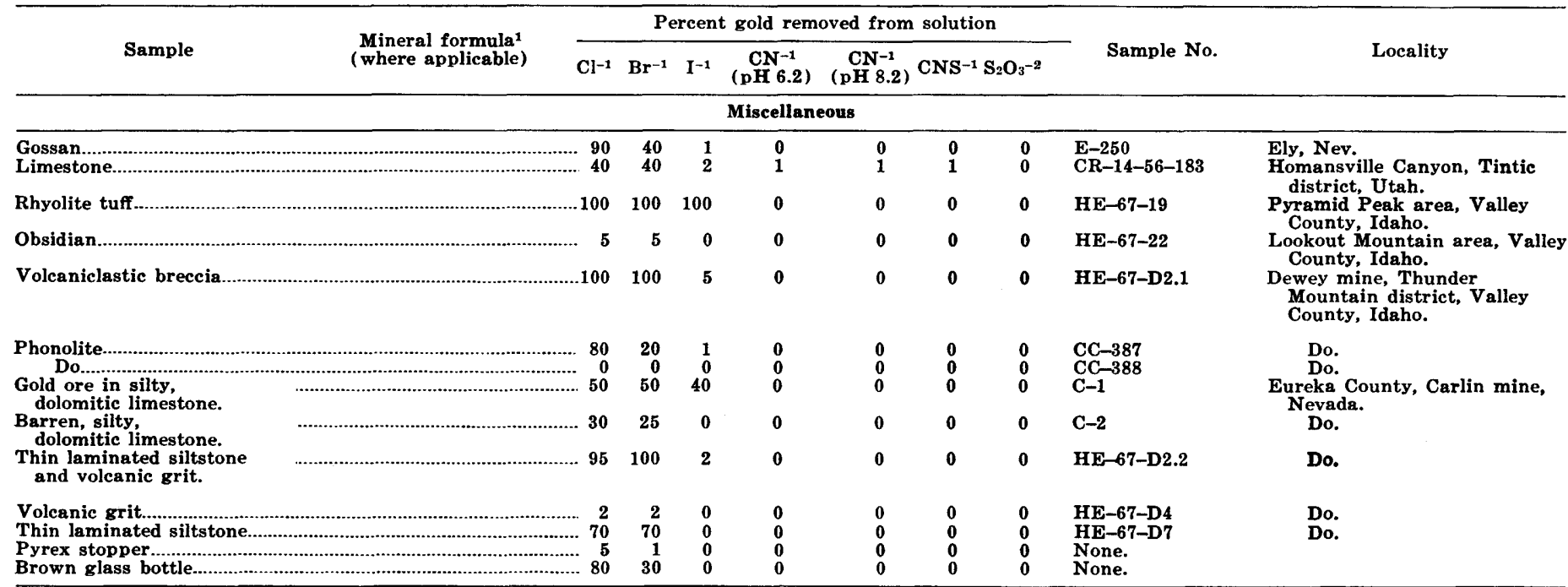

'Source of mineral formulas for sulfides, oxides, sulfates, carbonates, phosphates, vanadates, tungstates, and fluorides (except as otherwise noted) : Palache, Berman, and Frondel. Vol. 1, 1944 and Vol. 2, 1951.

"Source of mineral formulas : B. F. Leonard (written commun., 1969).

'Source of mineral formulas: Fleischer (1971).

Source of mineral formulas for silicates, except as otherwise noted: Deer, Howie, and Zussman (1966)

SSource of formula for jarosite: A. J. Gude III (written commun., 1969). 
TABLE 4. - Removal, by minerals, of gold from solutions of various gold complexes as shown by the number of samples falling into each category of percentage of gold lost from solution

\begin{tabular}{|c|c|c|c|c|c|c|c|c|c|c|c|c|c|c|c|c|}
\hline Mineral group............. 造 & 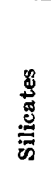 & 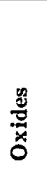 & 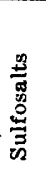 & 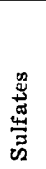 & 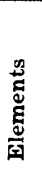 & 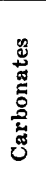 & 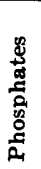 & 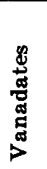 & 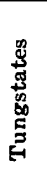 & 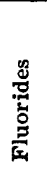 & $\sum_{0}^{\infty}$ & 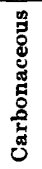 & 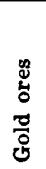 & 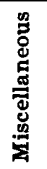 & 㺃 & 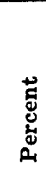 \\
\hline $\begin{array}{l}\text { Total number } \\
\text { of samples. }\end{array}$ & 30 & 26 & 1 & 3 & 2 & 5 & 2 & 1 & 1 & 1 & 3 & 7 & 6 & 6 & 114 & 100 \\
\hline $\begin{array}{l}\text { Percent Au } \\
\text { lost from } \\
\text { solution. }\end{array}$ & & & & & & & & 80 & & atin & perc & & u-lo & ost $\mathrm{c}$ & tegor & \\
\hline
\end{tabular}

\begin{tabular}{|c|c|c|c|c|c|c|c|c|c|c|c|c|c|c|c|c|}
\hline \multicolumn{17}{|c|}{ Gold chloride complex } \\
\hline $\begin{array}{l}90+ \\
60-<90 \\
40-<60 \ldots \\
>10-0<40\end{array}$ & $\begin{array}{l}7 \\
7 \\
6 \\
3 \\
7\end{array}$ & $\begin{array}{l}7 \\
3 \\
5 \\
7 \\
4\end{array}$ & $\begin{array}{l}1 \\
\cdots . \\
\cdots . \\
\cdots . \\
\cdots .\end{array}$ & $\begin{array}{l}\cdots . . \\
\cdots . \\
2 \\
1\end{array}$ & $\begin{array}{l}2 \\
\cdots \\
\cdots \\
\cdots \\
\cdots\end{array}$ & $\begin{array}{r}3 \\
\hdashline \mathbf{1}\end{array}$ & $\begin{array}{l}\cdots . \\
\cdots \\
1 \\
1\end{array}$ & $\begin{array}{l}\cdots . . \\
\cdots . \\
\cdots . \\
1\end{array}$ & $\begin{array}{l}1 \\
\ldots . \\
\cdots . \\
\cdots \\
\cdots\end{array}$ & $\begin{array}{l}\cdots . \\
\cdots . \\
\cdots . \\
1\end{array}$ & $\begin{array}{l}1 \\
\cdots . . \\
2 \\
2 . .\end{array}$ & $\begin{array}{r}5 \\
1 \\
\cdots \\
1 \\
\ldots . .\end{array}$ & $\begin{array}{l}2 \\
1 \\
1 \\
1 \\
1\end{array}$ & $\begin{array}{r}3 \\
1 \\
\cdots . . \\
2 .\end{array}$ & $\begin{array}{l}52 \\
13 \\
14 \\
16 \\
19\end{array}$ & $\begin{array}{l}45.6 \\
11.4 \\
12.2 \\
14.0 \\
16.7\end{array}$ \\
\hline \multicolumn{17}{|c|}{ Gold bromide complex } \\
\hline $\begin{array}{l}90+\ldots 19 \\
60-<90 \\
40-<60 \\
>10-<<40 \\
10-0\end{array}$ & $\begin{array}{l}7 \\
3 \\
4 \\
9 \\
7\end{array}$ & $\begin{array}{l}5 \\
2 \\
6 \\
7 \\
6\end{array}$ & $\begin{array}{l}1 \\
\cdots . \\
\cdots . \\
\cdots . . \\
\cdots .\end{array}$ & $\begin{array}{l}\cdots . \\
\cdots, \\
1 \\
1\end{array}$ & $\begin{array}{l}2 \\
\cdots . \\
\cdots \\
\cdots \\
\cdots\end{array}$ & $\begin{array}{r}2 \\
\cdots 2 \\
\cdots \\
1\end{array}$ & $\begin{array}{l}\cdots \\
1 \\
1 \\
1\end{array}$ & $\begin{array}{l}\cdots . \\
\cdots . . \\
\cdots \\
1\end{array}$ & $\begin{array}{l}1 \\
\cdots . \\
\cdots . \\
\cdots .\end{array}$ & $\begin{array}{l}\cdots . \\
\cdots . . \\
\cdots \\
1\end{array}$ & $\begin{array}{l}\cdots \\
1 \\
1 \\
\cdots\end{array}$ & $\begin{array}{r}5 \\
1 \\
\cdots \\
1\end{array}$ & $\begin{array}{l}2 \\
\cdots \\
1 \\
2 \\
1\end{array}$ & $\begin{array}{l}3 \\
1 \\
\cdots \\
\cdots\end{array}$ & $\begin{array}{r}47 \\
8 \\
16 \\
21 \\
22\end{array}$ & $\begin{array}{r}41.2 \\
7.0 \\
14.0 \\
18.4 \\
19.3\end{array}$ \\
\hline \multicolumn{17}{|c|}{ Gold iodide complex } \\
\hline $\begin{array}{l}90+ \\
60-<90 \\
40-<60 \\
>10-040 \\
10-0\end{array}$ & $\begin{array}{r}1 \\
\cdots \\
1 \\
2 \\
26\end{array}$ & $\begin{array}{r}1 \\
\cdots . . \\
2 \\
23\end{array}$ & $\begin{array}{l}\cdots \\
1 \\
\cdots . . \\
\cdots .\end{array}$ & $\begin{array}{r}\cdots . \\
1 \\
\cdots . \\
2\end{array}$ & $\begin{array}{l}2 \\
\cdots . \\
\cdots . \\
\cdots . \\
\cdots\end{array}$ & $\begin{array}{l}\cdots . . \\
\cdots \\
1 \\
4\end{array}$ & $\begin{array}{l}\cdots . . \\
\cdots . . \\
1 \\
1\end{array}$ & $\begin{array}{l}\cdots \\
\cdots \\
\cdots \\
1\end{array}$ & $\begin{array}{l}1 \\
\cdots . . \\
\cdots . \\
\cdots\end{array}$ & $\cdots$. & $\begin{array}{l}\cdots . \\
\cdots . . \\
\cdots . . \\
\cdots\end{array}$ & $\begin{array}{r}2 \\
2 \\
\cdots \\
1 \\
2\end{array}$ & $\begin{array}{r}2 \\
\cdots \\
\cdots \\
\cdots\end{array}$ & $\begin{array}{c}1 \\
\ldots . . \\
\cdots . . \\
\cdots \\
\mathbf{5}\end{array}$ & $\begin{array}{r}23 \\
5 \\
\mathbf{3} \\
\mathbf{7} \\
76\end{array}$ & $\begin{array}{r}20.2 \\
4.4 \\
2.6 \\
6.1 \\
66.6\end{array}$ \\
\hline
\end{tabular}

Gold cyanide complex pH 6.2

\begin{tabular}{|c|c|c|c|c|c|c|c|c|c|c|c|c|c|c|c|c|}
\hline (16) & $\begin{array}{l}\cdots . \\
\cdots . \\
\cdots . . \\
30\end{array}$ & $\begin{array}{l}\cdots . . \\
\cdots . . \\
26\end{array}$ & $\begin{array}{l}1 \\
\cdots . . \\
\cdots . . \\
\cdots . .\end{array}$ & $\begin{array}{l}\cdots . \\
\cdots . . \\
\cdots . \\
3 .\end{array}$ & $\begin{array}{l}\cdots \\
1 \\
\cdots . . \\
1 \\
1\end{array}$ & $\begin{array}{l}1 \\
\cdots . \\
\cdots \\
\cdots \\
4\end{array}$ & $\begin{array}{l}\cdots . \\
\cdots . . \\
\cdots . . \\
2 .\end{array}$ & $\begin{array}{l}\cdots . \\
\cdots . \\
\cdots . \\
\cdots\end{array}$ & $\begin{array}{l}\cdots . \\
\cdots . . \\
\cdots . \\
1\end{array}$ & $\begin{array}{l}\cdots . . \\
\cdots . . \\
\cdots . \\
1\end{array}$ & $\begin{array}{l}\cdots . . \\
\cdots . \\
\cdots . \\
\cdots\end{array}$ & $\dddot{\mathbf{3}}$ & $\begin{array}{c}\cdots . \\
\cdots \\
\cdots \\
\cdots \\
5\end{array}$ & $\begin{array}{l}\cdots . . \\
\cdots . . \\
\cdots . . \\
6\end{array}$ & & 3. \\
\hline
\end{tabular}

Gold cyanide complex pH 8.2

\begin{tabular}{|c|c|c|c|c|c|c|c|c|c|c|c|c|c|c|c|c|}
\hline 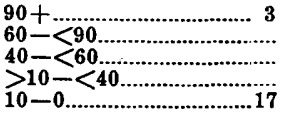 & $\begin{array}{l}\cdots . . \\
\cdots . . \\
\cdots \\
\mathbf{3 0}\end{array}$ & $\begin{array}{l}\cdots \\
\cdots \\
\cdots \\
26\end{array}$ & $\begin{array}{l}1 \\
\cdots \\
\cdots \\
\cdots \\
\cdots\end{array}$ & $\begin{array}{l}\cdots . . \\
\cdots \\
\cdots \\
\cdots\end{array}$ & $\begin{array}{c}\cdots \\
1 \\
1\end{array}$ & $\begin{array}{c}1 \\
\cdots \\
\cdots \\
\cdots\end{array}$ & $\begin{array}{l}\cdots . . \\
\cdots . . \\
\cdots\end{array}$ & $\begin{array}{l}\cdots . . \\
\cdots . \\
\cdots \\
\cdots\end{array}$ & $\begin{array}{l}\cdots . . \\
\cdots \\
\cdots \\
1\end{array}$ & $\begin{array}{l}\cdots . . \\
\cdots \cdots \\
\cdots \\
1\end{array}$ & $\begin{array}{l}\cdots . . \\
\cdots . . \\
\cdots \\
\cdots\end{array}$ & $\begin{array}{r}1 \\
\cdots \\
3 \\
\mathbf{3}\end{array}$ & $\begin{array}{l}\cdots . . \\
\cdots \\
\cdots \\
\cdots\end{array}$ & $\begin{array}{l}\cdots . . \\
\cdots \\
\cdots\end{array}$ & $\begin{array}{r}6 \\
0 \\
4 \\
0 \\
104\end{array}$ & $\begin{array}{l}5.3 \\
0 \\
\mathbf{3} .4 \\
0 \\
91.2\end{array}$ \\
\hline
\end{tabular}

\begin{tabular}{|c|c|c|c|c|c|c|c|c|c|c|c|c|c|c|c|c|}
\hline 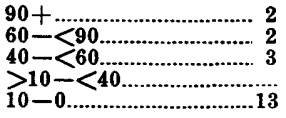 & $\begin{array}{l}\cdots . . \\
\cdots . . \\
\cdots \\
30\end{array}$ & $\begin{array}{r}\cdots \\
\cdots \\
\cdots \\
1 \\
25\end{array}$ & $\begin{array}{c}\cdots \\
\mathbf{1} \\
\cdots \\
\cdots \\
\cdots\end{array}$ & $\begin{array}{c}\ldots . . \\
\cdots \\
\cdots \\
\cdots \\
3\end{array}$ & $\begin{array}{c}\cdots \\
1 \\
\cdots \\
\cdots\end{array}$ & $\begin{array}{c}\cdots \\
\cdots \\
\cdots \\
\cdots \\
\mathbf{5}\end{array}$ & $\begin{array}{c}\cdots . . \\
\cdots \cdots \\
\cdots \cdots \\
\ldots\end{array}$ & $\begin{array}{c}\cdots \cdot \\
\cdots \\
\cdots \\
\cdots \\
\cdots \\
1\end{array}$ & $\begin{array}{c}\cdots . . \\
\cdots \\
\cdots \\
\ldots . \\
1\end{array}$ & $\begin{array}{c}\cdots . . \\
\cdots \\
\cdots \\
\cdots \\
1\end{array}$ & $\begin{array}{c}\cdots . . \\
\cdots . . \\
\cdots \\
\cdots \\
3\end{array}$ & $\begin{array}{l}\mathbf{2} \\
\mathbf{2} \\
\mathbf{1} \\
\mathbf{2}\end{array}$ & $\begin{array}{l}\cdots . . \\
\cdots \\
\cdots \\
6 . .\end{array}$ & $\begin{array}{l}\cdots . . \\
\cdots \\
\cdots \\
\cdots\end{array}$ & $\begin{array}{r}4 \\
6 \\
4 \\
2 \\
98\end{array}$ & $\begin{array}{r}3.4 \\
5.3 \\
3.4 \\
1.7 \\
86.1\end{array}$ \\
\hline
\end{tabular}

Gold thiosulfate complex

\begin{tabular}{|c|c|c|c|c|c|c|c|c|c|c|c|c|c|c|c|c|}
\hline 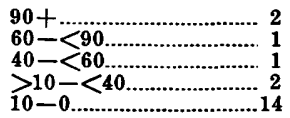 & $\begin{array}{l}\cdots \cdots \\
\cdots \\
\cdots \\
\cdots \\
\mathbf{3 0}\end{array}$ & $\begin{array}{r}1 \\
1 \\
\cdots \\
24\end{array}$ & $\begin{array}{c}\cdots . . \\
\cdots \\
\cdots \\
\cdots \\
1\end{array}$ & $\begin{array}{c}\cdots \cdot \\
\cdots \\
\cdots \\
\cdots \\
3\end{array}$ & $\begin{array}{c}\cdots . . \\
\cdots . . \\
\cdots \\
\cdots \\
2 .\end{array}$ & $\begin{array}{c}\cdots \\
\cdots \\
\cdots \\
\cdots \\
\cdots \\
5\end{array}$ & $\begin{array}{c}\cdots \\
\cdots \cdots \\
\cdots \cdots \\
2\end{array}$ & $\begin{array}{c}\cdots \\
\cdots \\
\cdots \\
\cdots \\
\cdots\end{array}$ & $\begin{array}{c}\cdots \\
\cdots \\
\cdots \\
\cdots \\
\cdots\end{array}$ & $\begin{array}{c}\cdots \\
\cdots \\
\cdots \\
\cdots \\
\cdots\end{array}$ & $\begin{array}{c}\cdots \\
1 \\
\cdots \\
\cdots \\
2\end{array}$ & $\begin{array}{c}\cdots \\
\mathbf{1} \\
\mathbf{1}\end{array}$ & $\cdots$ & $\begin{array}{c}\cdots \\
\cdots \\
\cdots \\
\cdots\end{array}$ & $\begin{array}{r}3 \\
3 \\
2 \\
3 \\
108\end{array}$ & $\begin{array}{r}2.6 \\
2.6 \\
1.7 \\
2.6 \\
90.4\end{array}$ \\
\hline
\end{tabular}

each of four different pulverized materials were separately mixed with $30 \mathrm{ml}$ of $3 \mathrm{~N} \mathrm{HCl}, 30 \mathrm{ml}$ of concentrated $\mathrm{HBr}$, and $30 \mathrm{ml}$ of $0.25 \mathrm{~N} \mathrm{KCN}$. Each of these solutions originally contained $15 \mu \mathrm{g}$ (micrograms) gold. Allowed to stand overnight, the series of mix- 
tures was centrifuged, and gold was determined in the supernatant liquid. Quartz flour was also mixed with the above solutions, and no measurable loss of gold from solution was observed. Table 5 shows that the $\mathrm{AuCl}_{4}{ }^{-1}$ and $\mathrm{AuBr}_{4}^{-1}$ complexes are nearly completely removed (94 to 100 percent) from solution by the four different carbonaceous materials, whereas the $\mathrm{Au}(\mathrm{CN})_{2}{ }^{-1}$ complex is removed to a less extent in all but the siliceous black shale. Rickard's (1897, p. 978-979) experiment demonstrated the precipitation of elemental gold on a black shale from a chloride solution of gold. The removal of gold from a gold cyanide solution may, however, be due to adsorption of the complex on the shale rather than to reduction of gold.

TABLE 5. - Percentage of gold complex removed from solution by a 10-gram powder sample of carbonaceous material

\begin{tabular}{|c|c|c|c|}
\hline 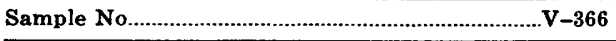 & $V-437 \mathrm{U}$ & $\mathrm{C}-1$ & 1759 \\
\hline Gold content of sample (ppm) & $<0.04$ & 0.34 & $<0.04$ \\
\hline Treatment & \multicolumn{3}{|c|}{ Percentage of added Au removed from solution } \\
\hline 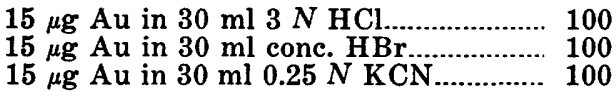 & $\begin{array}{l}(1) \\
94 \\
18\end{array}$ & $\begin{array}{r}100 \\
100 \\
70\end{array}$ & $\begin{array}{l}100 \\
(1) \\
70\end{array}$ \\
\hline
\end{tabular}

IInsufficient sample to run all three experiments.

SAMPLE DESCRIPTIONS

V-366. Siliceous black shale from Polk Creek Shale (Ordovician), sec. 2, T. 1 N., R. 15 W., Saline County, Ark. Collected by J. D. Vine.

V-437U. Oil shale from Mahogany ledge, Green River Formation (Eocene), John Savage quarry, sec. 36, T, 7 S., R. 97 W., Garfield County, Colo. Collected by J. D. Vine. C-1. Carbonaceous seam from Carlin gold mine, Lynn district, Eureka County, Nev. Col1759. Anthracite coal, Illinois. Collected by J. D. Vine.

\section{ABSORPTION OF GOLD BY PLANTS AS A FUNCTION OF COMPLEX STABILITY}

It is well established that gold is found in vegetation. The literature on gold in plants has been comprehensively reviewed by Jones (1970). How gold is transported from the soil into the plant has been the subject of much speculation. As a facet of this study of the geochemistry of gold, a cooperative study of the absorption of gold by plants was made with $\mathrm{H}$. T. Shacklette. The results of this study and related studies are reported in this section.

In the experiments reported by Shacklette, Lakin, Hubert, and Curtin (1970), colloidal gold is not absorbed by rooted or unrooted cuttings of two species of Impatiens. Two sols (colloidal gold preparations) were used: (1) A sol prepared by reduction of $\mathrm{HAu}^{198} \mathrm{Cl}_{4}$ with glucose in the presence of gelatin (probable maximum diameter of gold particles less than $0.05 \mu \mathrm{m}$ (micrometer)), and (2) a sol prepared by reduction of $\mathrm{HAu}^{198} \mathrm{Cl}_{4}$ with sodium 
oxalate (probable diameter of gold particles $<0.45 \mu \mathrm{m}$ and $>0.05$ $\mu \mathrm{m})$. The facts that neither of these sols produced leaf images in autoradiographs of the leaves of rooted cuttings of Impatiens and that the stems and leaves remained alive and seemed to sustain no cell damage discredit any assumption that colloidal gold is taken up by plants.

Under certain conditions gold in the form of gold chloride at $\mathrm{pH} 6.2$ is taken up by plants. The amount of gold absorbed from nonradioactive solutions of gold chloride at $\mathrm{pH} 6.2$ by rooted Impatiens plants was found to be 1 and $7.5 \mathrm{ppm}$ in the ash of the two plants grown in solutions containing $5.7 \mathrm{ppm}$ gold. Lack of images on the autoradiographs of leaves taken from rooted Impatiens showed that no absorption of $\mathrm{Au}^{198}$ took place from gold chloride solutions at $\mathrm{pH}$ 6.2. Perhaps gold was reduced in the short plant stem between the solution and the leaf. Also, gold was reduced quantitatively in 48 hours by onion roots, as evidenced by a blue suspension in the solution and coating on the roots; new growth onion roots were white, indicating that no gold remained in solution.

Gold in gold bromide solutions is more readily taken up by plants. Slight reduction of gold by plant roots was observed with gold bromide solutions, and faint autoradiographs indicated absorption by the plant. Measurement of absorbed gold by atomic absorption gave 28 and $39 \mathrm{ppm}$ gold in ash of plants grown in solutions containing $29 \mathrm{ppm}$ gold.

On the other hand, the gold iodide and gold thiocyanate solutions were toxic to severely toxic to the plants, and gold absorption was erratic. The Impatiens holstii absorbed $64 \mathrm{ppm}$ gold (ash basis) from the gold iodide solution compared with $2.7 \mathrm{ppm}$ in the ash of Impatiens balsamina. Less than $1 \mathrm{ppm}$ gold was found in the ash of these plants growing in gold thiocyanate solutions.

Gold thiosulfate behaved similarly to gold chloride in that it was not absorbed in the radioactive gold experiments and was found in the ash of the plants grown in gold thiosulfate solutions.

Greater amounts of gold were absorbed by the plants from gold cyanide solutions than from any other gold complexes tested. Of special interest are the results obtained by gold cyanide solutions prepared by the action of a slurry of the cyanogenic plant, wild flax (Linum lewisii Pursh), upon leaf gold. A slurry of the aboveground parts of wild flax at the flowering stage was made in a blender and diluted with water; leaf gold was added, and the mixture was allowed to stand for 3 days. The slurry was centrifuged, and the supernatant solution was found to contain $0.5 \mathrm{ppm}$ gold. Radioactive gold cyanide was added to the supernatant liquid, and 
rooted Impatiens was grown in the liquid. Rooted Impatiens absorbed gold from this supernatant liquid.

In a subsequent experiment mountain ash twigs and leaves were ground in a blender with water, gold leaf was added, and the slurry was allowed to stand for 1 week. After centrifuging to remove much of the plant material and all the undissolved leaf gold, the plant extract contained $0.5 \mathrm{ppm}$ gold. Rooted cuttings of Impatiens were placed in this plant extract. The cuttings were severely wilted after 2 days and were dead at the end of 5 days. The plant tips, separated by a shield from the plant extract, were excised and dried. The dried plants weighed $8.5 \mathrm{~g}$ and contained $3 \mu \mathrm{g}$ of gold ( $0.35 \mathrm{ppm}$ gold). The solubilization of gold by a plant extract and the subsequent uptake of $3 \mu \mathrm{g}$ of gold from this extract demonstrates a natural process by which gold can be solubilized and absorbed by plants.

The interaction of the biological system and the aqueous solutions of high ionic strength used in the experiments make interpretation of the data in a quantitative manner most difficult. Some relationships are shown by the data, however, in that, although the results of the experiments with the iodide, thiocyanate, and thiosulfate solutions are erratic, a correlation exists between gold absorbed by the plants and the stability of the chloride, bromide, and cyanide (table 6) complexes. The gold absorption coefficient for plants is defined here as the ratio of the gold absorbed by the plants, in parts per million, in ash of the plants to the gold content, in parts per million, of the nutrient solution. This absorption coefficient increases from chloride through bromide to cyanide complexes which is the order of increasing stability of the complexes.

In summary, colloidal gold is not absorbed by the plants investigated. Gold chloride and bromide may be reduced by the action of the roots of plants at $\mathrm{pH}$ 6.2. The most strongly absorbed complex of gold is the cyanide complex, which is also the most stable complex studied. It is also available in auriferous areas inhabitated by cyanogenic organisms. The absorption coefficient of gold complex by two species of Impatiens (table 6) increases with the stability of the complex.

TABLE 6. - Variation of gold absorption coefficients with three gold complexes for two species of Impatiens

\begin{tabular}{|c|c|c|c|}
\hline \multirow{2}{*}{ Plant } & \multicolumn{3}{|c|}{$\begin{array}{c}\text { Ratio of gold in ash of plants to gold in nutrient } \\
\text { solution (ppm) }\end{array}$} \\
\hline & $\mathrm{Cl}$ & $\mathbf{B r}$ & CN \\
\hline $\begin{array}{l}\text { Impatiens holst } \\
\text { balsamina }\end{array}$ & $\begin{array}{l}0.17 \\
1.30\end{array}$ & $\begin{array}{l}1.0 \\
1.34\end{array}$ & $\begin{array}{l}5.5 \\
2.7\end{array}$ \\
\hline
\end{tabular}




\section{GOLD CHLORIDE}

Gold chloride has been postulated as the probable mobile form of gold by many investigators. Emmons $(1917$, p. 323) reviewed the literature of the time and summarized the knowledge of the solution, migration, and enrichment of gold in mineral deposits as follows:

In nature the conditions that are favorable, if not essential, for gold enrichment are (1) chloride solutions, (2) iron sulfides, (3) manganese compounds. Where these conditions are supplied and where no very effective precipitant is at hand and erosion is not too rapid, gold placers are rarely formed, and outcrops of gold ores are likely to be less rich than the ores that lie deeper. Where these conditions exist and where the lodes are fractured, gold will migrate downward.

More recently Krauskopf (1951, p. 869) summarized his studies :

(1) Solubilities of gold calculated from thermodynamic data agree reasonably well with experimental results. (2) In acid solutions gold may be transported as the ion $\mathrm{AuCl}_{4}^{-}$, provided that reducing agents are absent. The metal is dissolved by an acid solution provided that the solution contains $\mathrm{Cl}^{-}$and that a fairly strong oxidizing agent is present. At high temperatures and pressures the hydrogen ion of the acid is a sufficiently strong oxidizing agent: at low temperatures a substance like $\mathrm{MnO}_{2}, \mathrm{O}_{2}, \mathrm{Fe}^{+++}$, or $\mathrm{Cu}^{++}$must be present in addition. The requirement that an oxidizing agent be present, or at least that a reducing agent be absent, probably means that the gold chloride ion would not be transported in acid vein solutions at low temperatures, since such solutions would contain reducing agents like $\mathrm{H}_{2} \mathrm{~S}$ and $\mathrm{Fe}^{++}$. On the other hand, solution and transport of gold in acid solution is probably the mechanism of supergene movement of gold.

The solution of gold by $\mathrm{MnO}_{2}$ in $1 \mathrm{M} \mathrm{HCl}$ (Krauskopf, 1951, p. 862 ) is expressed by the equation $2 \mathrm{Au}+12 \mathrm{H}+1+3 \mathrm{MnO}_{2}+8 \mathrm{Cl}^{-1}$ $=3 \mathrm{Mn}^{+2}+2 \mathrm{AuCl}_{4}{ }^{-1}+6 \mathrm{H}_{2} \mathrm{O}$ with $E=+0.28 \mathrm{~V}, \Delta F^{\circ}=-38,000 \mathrm{cal}$, and $K=\mathrm{cal}^{28}$. The positive electromotive force, the negative freeenergy change, and the large equilibrium constant for the reaction indicate that gold is soluble.

Krauskopf $(1951$, p. 863$)$ has given a similar equation for the solubility of gold in $1 \mathrm{M} \mathrm{HCl}$ and atmospheric oxygen: $2 \mathrm{Au}+6 \mathrm{H}^{+1}$ $+3 / 2 \mathrm{O}_{2}+8 \mathrm{Cl}^{-1}=2 \mathrm{AuCl}_{4}{ }^{-1}+3 \mathrm{H}_{2} \mathrm{O}$. Both of these reactions are very sensitive to changes in the concentrations of hydrogen and chloride ions.

Table 7 gives some values of the solubility of gold calculated by Krauskopf (1951, tables 3, 4, p. 862-863) in $\mathrm{HCl}+\mathrm{MnO}_{2}$ and in $\mathrm{HCl}+\mathrm{O}_{2}$ at $25^{\circ} \mathrm{C}$.

Thus, gold chloride can be formed in acid solution in the presence of $\mathrm{MnO}_{2}, \mathrm{O}_{2}, \mathrm{Fe}^{+3}$ or $\mathrm{Cu}^{+2}$, but it requires conditions not commonly found in nature.

The calculations given by Krauskopf (table 7) show that at concentrations of $10^{-3} M \mathrm{H}^{+1}$ and $\mathrm{Cl}^{-1}$ equivalent to $\mathrm{pH} 3$ and $35 \mathrm{ppm} \mathrm{Cl}-1$, the solubility of gold in the presence of $\mathrm{MnO}_{2}$ is 
TABLE 7. - Solubilities of gold in hydrochloric acid

[From Krauskopf (1951, tables 3 and 4, p. 862-863)]

\begin{tabular}{cccccc}
\hline $\begin{array}{c}\text { Concentration of } \\
\mathrm{H}^{+1}(\mathrm{~mole} / \mathrm{l})\end{array}$ & $\begin{array}{c}\text { Concentration of } \\
\mathrm{Cl}^{-1}(\mathrm{~mole} / \mathrm{l})\end{array}$ & \multicolumn{2}{c}{$\begin{array}{c}\text { Solubility of } \mathrm{Au} \text { in } \\
\mathrm{HCl}+\mathrm{MnO}_{2} \text { at } 25^{\circ} \mathrm{C}\end{array}$} & \multicolumn{2}{c}{$\begin{array}{c}\text { Solubility of } \mathrm{Au} \text { in } \\
\mathbf{H C l}+\mathrm{O}_{2} \text { at } 25^{\circ} \mathrm{C}\end{array}$} \\
\cline { 3 - 7 } & & $\begin{array}{c}\mathrm{Au} \\
(\mathrm{mole} / 1)\end{array}$ & $\begin{array}{c}\mathrm{Au} \\
(\mathrm{gram} / 1)\end{array}$ & $\begin{array}{c}\mathrm{Au} \\
(\mathrm{mole} / 1)\end{array}$ & $\begin{array}{c}\mathrm{Au} \\
\text { (gram/1) }\end{array}$ \\
\hline $10^{-4}$ & 1 & $10^{-4}$ & 0.02 & 0.1 & 20 \\
$10^{-6}$ & 1 & $10^{-9}$ & $2 \times 10^{-7}$ & $10^{-7}$ & $2 \times 10^{-5}$ \\
1 & $10^{-4}$ & .1 & 20 & $10^{-5}$ & .002 \\
$10^{-2}$ & $10^{-2}$ & $10^{-2}$ & 2 & $10^{-3}$ & .2 \\
$10^{-3}$ & $10^{-3}$ & $10^{-6}$ & $2 \times 10^{-4}$ & $10^{-10}$ & $2 \times 10^{-8}$ \\
\hline
\end{tabular}

$0.2 \mathrm{ppm}$. Lovering and Morris (1965, table 3, p. F16) reported $70 \mathrm{ppm}$ chloride in downward-moving acid sulfate water from the North Lily mine, Tintic district, Utah. In the nearby Tintic Standard mine, Morris and Lovering $(1952$, p. 693) found chalcanthite $\left(\mathrm{CuSO}_{4} \cdot 5 \mathrm{H}_{2} \mathrm{O}\right) 25$ feet from the ore zone that contained $2.7 \mathrm{ppm}$ gold $(0.08 \mathrm{oz} /$ ton $)$. Although the gold may be in a colloidal form in this mineral, it is reasonable to assume that Krauskopf's conditions of solubility had been met and gold chloride had moved a short distance in solution.

Cloke and Kelly $(1964$, p. 269) studied the solubility of gold in the presence of chloride solutions and arrived at conclusions similar to those of Krauskopf.

The present practice of leaching porphyry copper dumps with dilute sulfuric acid solutions is carried out in sufficiently acid solutions to satisfy, in the presence of sufficient chloride ion, the requirements given by Krauskopf for solution of gold. Beall (1965, p. 81) gave data on the $\mathrm{pH}$ and composition of leach solutions at seven commercial copper leaching operations in or adjacent to Arizona. Using these data, we prepared solutions approximating the input and output solutions in copper, iron, aluminum content, and $\mathrm{pH}$. Aluminum content was not given by Beall; however, we estimated it to be the same as iron. Sodium chloride and manganese dioxide, together with $0.5 \mathrm{~g}$ of gold shavings, were added to aliquots of these solutions, and the solutions were allowed to stand. The data were obtained from a set of confounded factorial experiments (table 8) using the design given by Youden (1951, p. 112).

An analysis of variance can readily be made of the data in table 8 , but this would add little to the obvious facts that the solubility of gold increases independently with increasing concentrations of chloride ion, hydrogen ion, or manganese dioxide. An increase of twentyfold in the concentration of ferric and cupric ions actually resulted in a decrease of solution of gold in these experiments owing to the formation of ferric and cupric chloride complexes and the resultant decrease in the effective concentration of chloride ion. 
These experiments, reported in table 8 , show that leaf gold is readily dissolved in sulfuric acid solutions at acidities used in commercial leaching of copper if sufficient chloride ion and $\mathrm{MnO}_{2}$ are present. However, when these solutions are mixed with crushed ore, it appears that pockets of gold-oxidizing and gold-reducing regions develop, and the net result is no effective solution of gold because of the low stability of the gold chloride complex and its resultant low mobility (table 3 ).

To test the effectiveness of the solutions used in the experiments reported in table 8 , we added the acid solution of $\mathrm{pH} 2$, containing $3,500 \mathrm{ppm} \mathrm{Cl}-1$ and a large excess of $\mathrm{MnO}_{.}$, to a pulverized oxidized gold ore $(3.5 \mathrm{oz} /$ ton $\mathrm{Au})$ from ore at Carlin, Nev. Air was bubbled through the mixture to provide a stirring action, and sulfuric acid was added, as needed, to maintain the $\mathrm{pH}$ at 2 . After 1 month 10 percent of the gold was in solution. At the end of 2 months only 1 percent was in solution, and after 3 months no gold could be detected in solution $(<0.08$ percent of the gold in the ore). Thus, the gold initially dissolved was eventually lost from solution. The loss of gold from solution may be due to a reducing agent within the ore sample but is probably enhanced by an increase in ferric ion in solution and the consequent decrease in effective chloride ion, an effect which can be observed in the data of table 8 .

TABLE 8. - The interactions of the concentrations of $\mathrm{Cl}^{-1}, \mathrm{H}^{+1}$, and $\mathrm{MnO}_{2}$ on the solubility of gold in copper leach solutions

\begin{tabular}{|c|c|c|c|c|c|c|c|c|}
\hline $\begin{array}{l}\text { Average porphyry } \\
\text { copper leach solutions }\end{array}$ & \multicolumn{4}{|c|}{$\begin{array}{c}\text { Input sulfate solution } \\
\mathrm{Fe}^{+3}, \mathrm{Al}^{+3}, \mathrm{Cu}^{+2}=0.1 \mathrm{~g} / 1 \text { each }\end{array}$} & \multicolumn{4}{|c|}{$\begin{array}{c}\text { Output (pregnant) } \\
\text { sulfate solution } \\
\mathrm{Fe}^{+3}, \mathrm{Al}^{+3}, \mathrm{Cu}^{+2}=2 \mathrm{~g} / \mathrm{l} \text { each }\end{array}$} \\
\hline 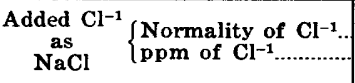 & \multicolumn{2}{|c|}{$1,700^{0.05}$} & \multicolumn{2}{|c|}{$3,500^{0.1}$} & \multicolumn{2}{|c|}{$1,700^{0.05}$} & \multicolumn{2}{|c|}{3,500} \\
\hline $\begin{array}{l}\text { pH at start } \\
\text { Approx. } H^{+1} \text {, in ppm. }\end{array}$ & 2.5 & 2.0 & $\begin{array}{l}2.5 \\
3\end{array}$ & 10 & 2.5 & 2.0 & $\begin{array}{l}2.5 \\
3\end{array}$ & 2.0 \\
\hline \multicolumn{9}{|c|}{ Parts per million of gold in solution after 3 weeks of contact with gold } \\
\hline $\begin{array}{l}\mathrm{No} \mathrm{MnO}_{2} \\
40 \mathrm{mg} / 1 / \mathrm{MnO}_{2} \\
200 \mathrm{mg} / 1 \mathrm{MnO}_{2}\end{array}$ & $\begin{array}{l}0.04 \\
.1 \\
.37\end{array}$ & $\begin{array}{c}<0.04 \\
2.4 \\
3.9\end{array}$ & $\underset{1}{.4}$ & $\begin{array}{c}<0.04 \\
5.3 \\
9.2\end{array}$ & $\begin{array}{r}<0.04 \\
<.04 \\
.05\end{array}$ & $\begin{array}{c}<0.04 \\
.95 \\
2.9\end{array}$ & $\begin{array}{r}<0.04 \\
.06 \\
.24\end{array}$ & $\begin{array}{c}<0.04 \\
3.9 \\
7.0\end{array}$ \\
\hline
\end{tabular}

The net effect observed in the copper industry will be loss of gold production as production of cement copper (product of leaching operation) increases. Gold produced by three mining companies in Arizona amounted to 0.04 to $0.35 \mathrm{oz} /$ ton of copper, which is equivalent to 1.4 to $12 \mathrm{ppm} \mathrm{Au}$ ( $\mathrm{Au}$ and $\mathrm{Ag}$ map and $\mathrm{Cu}$ map, American Cyanamid Co., 1965a, b). The gold recovered from copper in electrorefining amounted to 133,000 ounces for the three companies in 1965 . In contrast, 13 samples of cement copper col- 
lected from seven leach operations in Arizona were analyzed by F. O. Simon, using activation analyses (Rowe and Simon, 1968), and were found to contain from 0.007 to $0.066 \mathrm{ppm} \mathrm{Au}$. These data show that the increasing use of present leaching processes can result in the loss of many thousands of ounces of gold.

The likelihood of gold chloride being reduced has been emphasized by many workers. Rickard $(1897$, p. 978) extracted the gold from a piece of ore $(1,147 \mathrm{oz} /$ ton $\mathrm{Au})$ from Cripple Creek, Colo., with a solution of ferric sulfate, sodium chloride, and "a little free sulfuric acid." On subsequent immersion of a piece of carbonaceous shale from the Rico Formation in the solution, the gold was precipitated so rapidly that "gilding of the black shale by the deposit of gold became visible within four hours."

The data given in table 4 show that 45.6 percent of 114 materials removed more than 90 percent of the gold chloride from solution after a very short period of contact. These data also emphasize the relative immobility of gold chloride in a geologic environment.

\section{GOLD BROMIDE AND GOLD IODIDE}

\section{GEOCHEMISTRY OF BROMIDES AND IODIDES}

Bromides and, especially, iodides form more stable complexes with gold than do chlorides. The relative scarcity of these halogens in the earth's crust, however, reduces the probability of their effectiveness in the solution of gold. The crustal abundance given by Vinogradov (1962, table 4, p. 649) for the three halides are chlorine, $170 \mathrm{ppm}$; bromine, $2.1 \mathrm{ppm}$; and iodine, $0.4 \mathrm{ppm}$. The elements do not travel together in this relative abundance as shown in table 9. Bromine is concentrated in residual brines formed from waters evaporated by solar heat, whereas iodine is depleted, presumably by oxidation of iodides to give volatile-free iodine. Both bromine and iodine are concentrated in organic debris.

The presence of bromine in plants, marine organisms, and organic and oil-bearing sediments is similar to that of iodine, but bromine occurs in lesser amounts than iodine. Thus, in the iodine-rich waters of Java the highest bromine content reported was $68 \mathrm{ppm}$, compared with $150 \mathrm{ppm}$ for iodine (Bemmelen, 1949).

Iodine is markedly biophilic and is almost always more concentrated in the surface organic layer of soils than in lower horizons. In soils of the conterminous United States, the iodine content ranges from 0.015 to $40 \mathrm{ppm}$; in contrast, iodine in the soils of Hawaii ranges from 8.6 to $111 \mathrm{ppm}$ and averages $34 \mathrm{ppm}$ (Chilean Iodine Educational Bureau, 1956, tables 10, 12, p. 59-72, 86). The higher iodine content of Hawaiian soils can be attributed to iodine 
TABLE 9. - Abundance, in parts per million, of chlorine, bromine, and iodine and calculated relative aburidance of bromine and iodine in various earth materials

\begin{tabular}{|c|c|c|c|c|c|c|c|}
\hline \multirow[t]{2}{*}{ Material } & \multirow[t]{2}{*}{ Chlorine } & \multirow[t]{2}{*}{ Bromint: } & \multirow[t]{2}{*}{ Iodine } & \multirow[t]{2}{*}{$\begin{array}{l}\text { Bromine/ } \\
\text { iodine }\end{array}$} & \multicolumn{2}{|c|}{$\begin{array}{c}\text { Relative } \\
\text { abundance } \\
\mathrm{Cl}=100\end{array}$} & \multirow[t]{2}{*}{ Reference } \\
\hline & & & & & $\mathbf{B r}$ & $\mathbf{I}$ & \\
\hline $\begin{array}{l}\text { Earth's crust........... } \\
\text { Ultramafic rocks... }\end{array}$ & $\begin{array}{r}170 \\
85\end{array}$ & $\begin{array}{l}2.1 \\
1\end{array}$ & $\begin{array}{l}0.4 \\
.05\end{array}$ & 20 & $\begin{array}{l}1.3 \\
1.2\end{array}$ & $\begin{array}{c}0.24 \\
.6\end{array}$ & $\begin{array}{l}\text { Vinogradov (1962). } \\
\text { Turekian and } \\
\text { Wedepohl (1961). }\end{array}$ \\
\hline $\begin{array}{l}\text { Basalts. } \\
\text { Granite (high } \\
\text { calcium). }\end{array}$ & $\begin{array}{r}60 \\
130\end{array}$ & $\begin{array}{l}3.6 \\
4.5\end{array}$ & $\begin{array}{l}.05 \\
.05\end{array}$ & $\begin{array}{l}72 \\
90\end{array}$ & $\begin{array}{l}6.0 \\
3.6\end{array}$ & $\begin{array}{l}.8 \\
.4\end{array}$ & $\begin{array}{l}\text { Do. } \\
\text { Do. }\end{array}$ \\
\hline $\begin{array}{c}\text { Do...... (low } \\
\text { calcium). }\end{array}$ & 200 & 1.3 & .05 & 26 & .65 & .25 & Do. \\
\hline $\begin{array}{l}\text { Clays and shales.... } \\
\text { Shales......................... }\end{array}$ & $\begin{array}{ll}\cdots & 160 \\
\cdots & 180\end{array}$ & $\begin{array}{l}6 \\
4\end{array}$ & $\begin{array}{l}1 \\
2.2\end{array}$ & $\begin{array}{l}6 \\
1.8\end{array}$ & $\begin{array}{l}3.7 \\
2.2\end{array}$ & 1.2 & $\begin{array}{l}\text { Vinogradov (1962). } \\
\text { Turekian and } \\
\text { Wedepohl (1961). }\end{array}$ \\
\hline 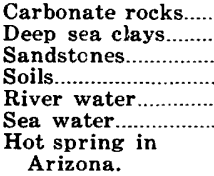 & $\begin{array}{lc}\ldots . & 150 \\
\ldots .21,000 \\
\ldots . & 10 \\
\ldots . & 100 \\
\ldots . & 8.3 \\
19,000 \\
43,790\end{array}$ & $\begin{array}{l}6.2 \\
70 \\
1 \\
5 \\
.006 \\
64.8\end{array}$ & $\begin{array}{l}1.2 \\
.05 \\
1.7 \\
5 \\
.0018 \\
.05 \\
.91\end{array}$ & $\begin{array}{c}1,400^{5.2} \\
1^{1.6} \\
1,300^{.3} \\
60\end{array}$ & $\begin{array}{c}4.1 \\
10^{.35} \\
5 \\
.075 \\
.33 \\
.13\end{array}$ & $\begin{array}{l}.8 \\
.00025 \\
17 \\
5 \\
.022 \\
.00025 \\
.0021\end{array}$ & $\begin{array}{l}\text { Do. } \\
\text { Do. } \\
\text { Do. } \\
\text { Vinogradov }(1959) \text {. } \\
\text { Correns }(1956) . \\
\text { Do. } \\
\text { Miyake }(1965) .\end{array}$ \\
\hline
\end{tabular}

in rainwater that was contributed to the atmosphere from oceanic evaporation and volcanic emanations. Vinogradov (1959, p. 54) postulated that much of the iodine enters the plants from the air and calculated that $1 \mathrm{mg}$ (milligram) of iodine per square meter per year is introduced into soils by plants. Iodine is also found in the colloid fraction of soils and in marine muds. Marine plants are exceptionally rich in iodine. Sediments containing the remains of these plants are rich in iodine, and brines squeezed out of such sediments are rich in iodine. For example, Bemmelen $(1949$, p. 186 ), in discussing the source of iodine from wells in Java (where iodine content averages $100-150 \mathrm{mg} / \mathrm{l}$ ) stated, "the iodine-bearing wells of the northern belt are related to oil and the source rocks of oil. Iodine is derived from neogene marine sediments which were deposited in an open sea at some distance from the coast. Those of the central belt are not related to oil and issue from Pleistocene littoral or lagoonal deposits. These brines have a lower alkalinity. The source of the iodine might be seaweeds accumulated along the coast. The disintegration of these weeds after burial by sediments caused the accumulated iodine to be liberated."

Marine muds from various Asian seas average about $25 \mathrm{ppm}$ iodine, and the iodine content of these marine muds increases approximately with the colloid content (Vinogradov, 1959). In oil shales the iodine content rises with increase in the oil content (Correns, 1956). Phosphate rocks of the world contain from 0.2 to $280 \mathrm{ppm}$ iodine, averaging about $30 \mathrm{ppm}$ (Chilean Iodine Educational Bureau, 1956, table 2, p. 2). 
TABLE 10. - The interactions of the concentrations of $\mathrm{Br}^{-1}, \mathrm{H}^{+1}$, and $\mathrm{MnO}_{2}$ on the solubility of gold in copper leach solutions

\begin{tabular}{|c|c|c|c|c|c|c|c|c|c|c|c|c|c|c|c|c|}
\hline \multirow{2}{*}{$\begin{array}{c}\begin{array}{c}\text { Average porphyry copper } \\
\text { leach solution }\end{array} \\
\begin{array}{c}\text { Added } \mathrm{Br}^{-1} \\
\text { as } \mathrm{NaBr}\end{array}\left\{\begin{array}{l}\text { Normality of } \mathrm{Br}^{-2} \\
\text { ppm of } \mathrm{Br}^{-1} \ldots \ldots\end{array}\right.\end{array}$} & \multicolumn{8}{|c|}{$\begin{array}{c}\text { Input sulfate solution } \\
\mathrm{Fe}^{+3}, \mathrm{Al}^{+3}, \mathrm{Cu}^{+2}=0.1 \mathrm{~g} / 1 \text { each }\end{array}$} & \multicolumn{8}{|c|}{$\begin{array}{l}\text { Output (pregnant) sulfate solution } \\
\mathrm{Fe}^{+3}, \mathrm{Al}^{+3}, \mathrm{Cu}^{+2}=2 \mathrm{~g} / \mathrm{l} \text { each }\end{array}$} \\
\hline & \multicolumn{2}{|c|}{400} & \multicolumn{2}{|c|}{800} & \multicolumn{2}{|c|}{4000} & \multicolumn{2}{|c|}{8000} & \multicolumn{2}{|c|}{40.005} & \multicolumn{2}{|c|}{800} & \multicolumn{2}{|c|}{4000} & \multicolumn{2}{|c|}{8000} \\
\hline $\begin{array}{l}\text { pH at start } \\
\text { Approx. } H^{+1} \text { in ppm. }\end{array}$ & $\frac{2.5}{3}$ & $10^{2.0}$ & 2.5 & 10 & 2.5 & 10 & 2.5 & 2.0 & ${ }_{3}^{2.5}$ & 2.0 & 2.5 & 2.0 & 2.5 & 2.0 & 2.5 & 10 \\
\hline \multicolumn{17}{|c|}{ Parts per million of gold in solution after 3 weeks of contact with gold } \\
\hline $\begin{array}{l}\mathrm{No}_{\mathrm{MnO}} \\
40 \mathrm{mg} / 1 \mathrm{MnO}_{2} \\
200 \mathrm{mg} / \mathrm{l} \mathrm{MnO}\end{array}$ & $\begin{array}{r}<0.04 \\
.13 \\
.24\end{array}$ & $\begin{array}{c}<0.04 \\
.50 \\
1.1\end{array}$ & $\begin{array}{l}0.05 \\
.50 \\
1.0\end{array}$ & $\begin{array}{l}0.11 \\
1.6 \\
2.9\end{array}$ & $\begin{array}{l}0.66 \\
3.4 \\
6.2\end{array}$ & $\begin{array}{l}0.94 \\
5.8 \\
6.7\end{array}$ & $\begin{array}{l}1.4 \\
5.5 \\
7.2\end{array}$ & $\begin{array}{l}1.8 \\
18 \\
21\end{array}$ & $\begin{array}{r}<0.04 \\
.06 \\
.06\end{array}$ & $\begin{array}{r}0.04 \\
.28 \\
.60\end{array}$ & $\begin{array}{r}0.12 \\
.30 \\
.16\end{array}$ & $\begin{array}{l}0.10 \\
.84 \\
1.6\end{array}$ & $\begin{array}{l}1.0 \\
1.5 \\
1.8\end{array}$ & $\begin{array}{l}1.1 \\
12 \\
13\end{array}$ & $\begin{array}{l}3.3 \\
4.5 \\
5.2\end{array}$ & $\begin{array}{l}4.4 \\
18 \\
16\end{array}$ \\
\hline
\end{tabular}

TABLE 11. - The interactions of the concentrations of $\mathrm{I}^{-1}, \mathrm{H}^{+1}$, and $\mathrm{MnO}_{2}$ on the solubility of gold in copper leach solutions

\begin{tabular}{|c|c|c|c|c|c|c|c|c|c|c|c|c|}
\hline $\begin{array}{c}\text { Average porphyry } \\
\text { copper leach solution }\end{array}$ & \multicolumn{6}{|c|}{$\begin{array}{c}\text { Input sulfate solution } \\
\mathrm{Fe}^{+3}, \mathrm{Al}^{+3}, \mathrm{Cu}^{+2}=0.1 \mathrm{~g} / 1 \text { each }\end{array}$} & \multicolumn{6}{|c|}{$\begin{array}{c}\text { Output (pregnant) sulfate solution } \\
\mathrm{Fe}^{+3}, \mathrm{Al}^{+3}, \mathrm{Cu}^{+2}=2 \mathrm{~g} / \mathrm{l} \text { each }\end{array}$} \\
\hline $\begin{array}{c}\text { Added } I^{-1} \\
\text { as NaI }\end{array}\left\{\begin{array}{l}\text { Normality of } I^{-1} \ldots \ldots \ldots \\
\text { ppm of } I^{-1} \ldots \ldots\end{array}\right.$ & \multicolumn{2}{|c|}{$13^{0.0001}$} & \multicolumn{2}{|c|}{130.001} & \multicolumn{2}{|c|}{640} & \multicolumn{2}{|c|}{13} & \multicolumn{2}{|c|}{$130^{0.001}$} & \multicolumn{2}{|c|}{640.005} \\
\hline 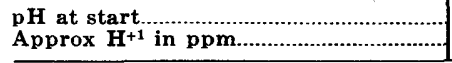 & $\begin{array}{l}2.5 \\
3 \\
\end{array}$ & $\begin{aligned} 2.0 \\
10\end{aligned}$ & $\begin{array}{l}2.5 \\
3\end{array}$ & 2.0 & $3^{2.5}$ & 2.0 & 2.5 & 2.0 & $\frac{2.5}{3}$ & 2.0 & $3^{2.5}$ & 2.0 \\
\hline \multicolumn{13}{|c|}{ Parts per million of gold in solution after 1 week of contact with gold } \\
\hline $\begin{array}{l}\mathrm{No} \mathrm{MnO}_{2} \\
40 \mathrm{mg} / \mathrm{MnO} \\
200 \mathrm{mg} / 1 \mathrm{MnO}_{2}\end{array}$ & $\stackrel{0.06}{<.04}$ & $\stackrel{0.10}{<.04}$ & $\begin{array}{l}5.5 \\
4.0 \\
0.9\end{array}$ & \begin{tabular}{|l|}
4.8 \\
1.2 \\
.06
\end{tabular} & $\begin{array}{l}>_{30}^{30} \\
>_{30}\end{array}$ & $\begin{array}{r}26 \\
>30 \\
14\end{array}$ & $\begin{aligned}<0.04 \\
<.04 \\
<.04\end{aligned}$ & $\begin{aligned}<0.04 \\
<.04 \\
<.04\end{aligned}$ & $\begin{array}{r}2.4 \\
1.5 \\
.2\end{array}$ & $\begin{array}{c}1.6 \\
<.7 \\
<.04\end{array}$ & $\begin{array}{l}\mathbf{3 0} \\
\mathbf{3}_{\mathbf{3 0}}\end{array}$ & $\begin{array}{r}>\mathbf{3 0} \\
27 \\
10\end{array}$ \\
\hline
\end{tabular}


Iodine is locally concentrated in volcanic springs, reaching $197 \mathrm{ppm}$ in a mineral spring in Japan (Miyake, 1965). Thus, iodine is concentrated in soils, organic marine sediments, phosphatic sediments, brines from marine sediments, and volcanic hot springs. Locally, the iodide concentration in waters leaching such sources is adequate to permit the solution of gold by $\mathrm{Fe}^{+3}$, $\mathrm{Cu}^{+2}$, or dissolved oxygen.

The bromine content of soils is about $5 \mathrm{ppm}$ (table 9) and the bromine-iodine ratio in soils ranges from 0.16 to 3 (Vinogradov, 1959, tables 23-27, p. 46--48). Compared with the earth's crust, soils are enriched in bromine, but not so greatly as they are enriched in iodine.

An abnormal accumulation of bromine $(850 \mathrm{ppm})$ was reported (Yamada, 1968, p. 1137) in a Japanese humic volcanic ash soil containing 17.4 percent carbon. In contrast with the high iodine contents in Hawaiian soils, T. T. Chao (written commun., 1972) found that bromides released from soil fumigants were readily leached by water with very little retention of bromine in the soil.

\section{FORMATION OF GOLD BROMIDE AND GOLD IODIDE}

The same experiments were made with addition of $\mathrm{NaBr}$ and $\mathrm{NaI}($ tables 10,11$)$ to average input and pregnant leach solutions that were made with $\mathrm{NaCl}$ (table 8). In the experiments with the bromide ion, the solubility of gold increases independently with increasing concentrations of bromide ion, hydrogen ion, or manganese dioxide, as was also observed in the chloride study; however, at concentrations of bromide ion of $800 \mathrm{ppm}$ and greater, gold was dissolved in the absence of manganese dioxide. In the experiments with the iodide ion, the solubility of gold increases independently with increasing concentration of iodide ion and hydrogen ion and decreases with increasing manganese dioxide. The" manganese dioxide oxidizes the iodide ion to iodine, which escapes from the system (Gale, 1971).

The solubility of gold decreased with a twentyfold increase in the concentration of iron and copper in the presence of a given concentration of bromine or iodine. As in the chloride system, this effect is due to removal of halide ions by formation of iron and copper halide complexes.

The increasing effectiveness of the sequence chloride-bromideiodide ions as complexing agents is apparent in these data. Thus, no measurable gold was dissolved with chlorides in the absence of manganese dioxide (table 8); appreciable gold was dissolved with bromide at $0.05 M$ and greater; more gold was dissolved with iodide in the absence of $\mathrm{MnO}_{2}$. Thus, although $\mathrm{Cu}^{+2}$ and $\mathrm{Fe}^{+3}$ 
are not adequate oxidants of gold in the formation of $\mathrm{AuCl}_{4}{ }^{-1}$, they do oxidize gold to $\mathrm{AuBr}_{4}^{-1}$ in $0.05 \mathrm{M} \mathrm{NaBr}$ solutions, and they oxidize gold in $0.0001 M \mathrm{NaI}$ solutions. To dissolve approximately the same amount of gold in a given time $(1.5 \mathrm{mg} / \mathrm{l}$ in 3 weeks) these solutions must contain either $1,800 \mathrm{ppm} \mathrm{Cl}^{-1}$ or $400 \mathrm{ppm} \mathrm{Br}^{-1}$ or as little as $13 \mathrm{ppm} \mathrm{I}^{-1}$, giving an equivalent effectiveness of $100 \mathrm{ppm} \mathrm{Cl}^{-1}=22 \mathrm{ppm} \mathrm{Br}^{-1}=0.7 \mathrm{ppm} \mathrm{I}^{-1}$.

When one considers that the relative crustal abundances of chlorine, bromine, and iodine are $100,1.3$, and 0.24 , respectively (table 9), it is evident that considerable enrichment of bromine and iodine is required for these elements to be as effective in solubilization of gold as chloride is in the acid solutions produced by oxidation of pyrite in gold deposits.

The strength of the $\mathrm{AuI}_{2}{ }^{-1}$ complex is shown by the oxidation of gold in the presence of $\mathrm{NaI}$ solutions in which the only oxidant is dissolved oxygen in the aqueous solution (table 12). When the $\mathrm{pH}$ of $\mathrm{NaI}$ solutions was adjusted with sulfuric acid or sodium hydroxide to give solutions ranging from $\mathrm{pH} 2.5$ to 9 , gold was dissolved throughout this $\mathrm{pH}$ range but was much more soluble in solutions of $\mathrm{pH} 2.5$ than in neutral to basic solutions. Neither gold chloride nor gold bromide is formed under these conditions.

The solubility of gold in four different ores in $0.05 M$ sodium iodide solutions varied with the $\mathrm{pH}$ of the solutions and the type of ore (table 13). No gold was dissolved from telluride ores, in contrast with 90 percent of the gold dissolved from massive pyrite ores, and 60-90 percent of the gold dissolved from oxidized ores. The decrease in dissolved gold after 14 days may be due to increased solution of iron resulting in complexing of iodide and thus decreasing effective iodide concentration, or the decrease in dissolved gold may be due to oxidation and subsequent loss of iodide. Gold is not solubilized in either chloride or bromide solutions under these conditions.

Chukhrov (1947) postulated the solution of gold in sulfide deposits by free bromine and iodine. Bromides and iodides are, as we have seen, active complexing agents, and $\mathrm{Fe}^{+3}$ and $\mathrm{Cu}^{+2}$ are adequate oxidants of gold in the presence of sufficient bromide and iodide ions.

It seems evident, however, that bromides, although forming a stronger complex with gold than chloride, will rarely, if ever, be present in sufficient concentrations to be of any importance in the solution of gold.

Iodides, although much less abundant than chlorides and bromides, may, in rare instances, influence the solution of gold. One is tempted to speculate on the possible solution of gold in Indonesia 
TABLE 12. - Solubility of leaf gold in $0.05 \mathrm{M}$ sodium iodide solutions adjusted to various $p H$ values

\begin{tabular}{ccccc}
\hline & & \multicolumn{3}{c}{ Dissolved gold $(\mathrm{ppm})$} \\
\cline { 2 - 5 } \cline { 3 - 4 } \cline { 4 - 5 } & After & 7 days & After 14 days & After 21 days \\
\hline 2.5 & 19.4 & 55.7 & 62 \\
5 & 1 & 2.2 & 21.8 \\
7 & .26 & .7 & .86 \\
9 & .14 & .4 & .6 \\
\hline
\end{tabular}

$1 \mathrm{pH}$ adjusted with sulfuric acid or sodium hydroxide, as required.

? Brown color of solution indicated oxidation of iodide to iodine.

TABLE 13. - Solubility of ore gold in $0.05 \mathrm{M}$ sodium iodide solutions adjusted to various $p H$ values

[ND, none detected]

\begin{tabular}{|c|c|c|c|c|c|}
\hline \multirow{2}{*}{$\underset{\mathbf{p H}}{\text { Adjusted }}$} & \multicolumn{3}{|c|}{ Dissolved gold $(\mathrm{mg} / \mathrm{l})$} & \multirow{2}{*}{ 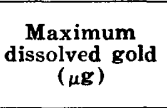 } & \multirow{2}{*}{$\begin{array}{l}\text { Percentage of gold } \\
\text { dissolved from ore }\end{array}$} \\
\hline & $\begin{array}{l}\text { After } \\
7 \text { days }\end{array}$ & $\begin{array}{c}\text { After } \\
14 \text { day; }\end{array}$ & $\begin{array}{l}\text { After } \\
\text { 21 days }\end{array}$ & & \\
\hline \multicolumn{6}{|c|}{ Sample No. EM-534-9-10. Gold 25 ppm } \\
\hline $\begin{array}{l}2.5 \\
5 \\
7 \\
9\end{array}$ & $\begin{array}{l}0.7 \\
.4 \\
.2 \\
.12\end{array}$ & $\begin{array}{l}0.9 \\
.5 \\
.2 \\
.14\end{array}$ & $\begin{array}{l}0.74 \\
.5 \\
.24 \\
.06\end{array}$ & $\begin{array}{r}225 \\
125 \\
50 \\
35\end{array}$ & $\begin{array}{l}90 \\
50 \\
20 \\
14\end{array}$ \\
\hline \multicolumn{6}{|c|}{ Sample No. GBG26. Gold $162 \mathrm{ppm}$} \\
\hline $\begin{array}{l}2.5 \\
5 \\
7 \\
9\end{array}$ & $\begin{array}{r}<0.04 \\
<.04 \\
<.04 \\
<.04\end{array}$ & $\begin{array}{l}<0.04 \\
<.04 \\
<.04 \\
<.04 \\
\end{array}$ & $\begin{array}{r}<0.04 \\
<.04 \\
<.04 \\
<.04 \\
\end{array}$ & $\begin{array}{l}\text { ND } \\
\text { ND } \\
\text { ND } \\
\text { ND }\end{array}$ & $\begin{array}{l}0 \\
0 \\
0 \\
0\end{array}$ \\
\hline \multicolumn{6}{|c|}{ Sample No. U75. Gold 79 ppm } \\
\hline $\begin{array}{l}2.5 \\
5 \\
7 \\
9\end{array}$ & $\begin{array}{l}1.96 \\
1.7 \\
1.6 \\
1.2\end{array}$ & $\begin{array}{l}2.9 \\
2.6 \\
2.9 \\
2.9\end{array}$ & $\begin{array}{l}2.2 \\
2.2 \\
2.2 \\
1.8\end{array}$ & $\begin{array}{l}715 \\
650 \\
715 \\
715\end{array}$ & $\begin{array}{l}90 \\
82 \\
90 \\
90\end{array}$ \\
\hline \multicolumn{6}{|c|}{ Sample No. D344. Gold 130 ppm } \\
\hline $\begin{array}{l}2.5 \\
5 \\
7 \\
9\end{array}$ & $\begin{array}{r}3.3 \\
.14 \\
<.04 \\
<.04\end{array}$ & $\begin{array}{l}3.5 \\
.16 \\
<.04 \\
<.04\end{array}$ & $\begin{array}{c}3.3 \\
.06 \\
<.04 \\
<.04\end{array}$ & $\begin{array}{r}875 \\
40 \\
\text { ND } \\
\text { ND }\end{array}$ & $\begin{array}{r}67 \\
3 \\
0 \\
0\end{array}$ \\
\hline
\end{tabular}

SAMPLE DESCRIPTIONS

EM-534-9-10. Fines from bedrock crevices at bottom of soil profile from Empire, Colo. Native gold with no observed sulfides. Berlrock is biotite gneiss containing only $0.04 \mathrm{ppm}$ gold.

GBG26. Volcanic breccia of phonolit:-latite composition containing gold telluride and minor antimony and silver. SW $1 / 4$ sec. 20 , T. $15 \mathrm{~N}$., R. 69 W. Cripple Creek district, Teller County, Colo. U75. Massive pyrite from dump of Atlantic shaft, Empire district, Clear Creek County, Colo. Collected by Maurice Chaffee.

D344. Massive gray jasperoid replacing dolomite; minor pyrite and hematite. Sec. 26, T. $14 \mathrm{~S}$., R. 11 W., Drum Mountains, Juab County, Utah. Collected by J. H. McCarthy, Jr.

by iodine-bearing ground waters and its subsequent reduction in streams or alluvial fans. The long history of more than 1,000 years of placer gold mining in these islands together with the juxtaposition of iodine-bearing hot springs and placer gold deposits in Java lends some support to the thought that the placers 
may result from precipitation of dissolved gold. The iodine content of many soils is adequate to dissolve gold if the iodine is available as an iodide.

In microenvironments in soils, sufficient iodide concentrations may be reached to result in solution of gold.

\section{GOLD THIOSULFATE}

\section{GEOCHEMISTRY OF THE THIOSULFATE ION}

Thiosulfate is a metastable ion that can be formed by the action of water on native sulfur in basic solutions. Thiosulfates and polythionates are commonly found in hot alkaline sulfur springs (Clarke, 1924, p. 196; White and others, 1963, table 21, p. F47; Day and Allen, 1925, p. 117 ; Blatchley, 1903, p. 76, 80, 87; Wilson, 1966, p. 680-681). Miyake (1965, p. 269), in a compilation of data, reported 10 springs in Japan containing thiosulfate with an average content of $0.11 \mathrm{ppm}\left(10^{-6} \mathrm{M}\right)$ and a maximum content of $37 \mathrm{ppm}\left(3 \times 10^{-4} M\right)$. Arntson, Dickson and Tunell (1960, p. 581) suggested the possible role of thiosulfate in forming soluble complexes with many metallic ions in hot alkaline sulfur waters.

Thiosulfates may be present in appreciable quantities in restricted marine environments. In an anoxic fjord on the southwestern coast of Vancouver Island, British Columbia, hydrogen sulfide accumulates in the deeper waters. Depletion of this hydrogen sulfide is assumed, by Cline and Richards (1969, p. 838), to occur in the transition zone where vertical diffusion brings oxygen and sulfide in contact. These authors studied the reaction of $\mathrm{H}_{2} \mathrm{~S}$ and dissolved oxygen in sterile salt water approximating the observed concentrations of hydrogen sulfide and oxygen. After about 50 hours, thiosulfate reached a maximum concentration of 30-35 percent of the initial sulfide concentration, sulfite reached 10-15 percent, and the remainder was presumed to be sulfate.

The presence of thiosulfates in soils is not easily demonstrated from direct data in the literature. The ionic species of sulfur in soils are in a constant state of flux. Sulfates may be reduced and elemental sulfur oxidized. A reaction of interest here is the oxidation of $\mathrm{S}^{-2}$ to $\mathrm{S}_{2} \mathrm{O}_{3}{ }^{-2}$ by the enzyme oxidase (Stevenson, 1964, p. 278). Plant and animal residues introduce a wide variety of sulfur compounds, including thiosulfates. Whitehead (1964, p. 3) stated that thiosulfates and polythionates occur transitorily in soils but are subject to either oxidation or reduction and do not accumulate. Organisms capable of oxidizing thiosulfates are common; they occur in most soils, upon rocks, in saltwater and freshwater, and in mineral springs (Starkey, 1935, p. 201). Thus, it would seem likely that thiosulfates are present in soils-in amounts varying erratically with time. 


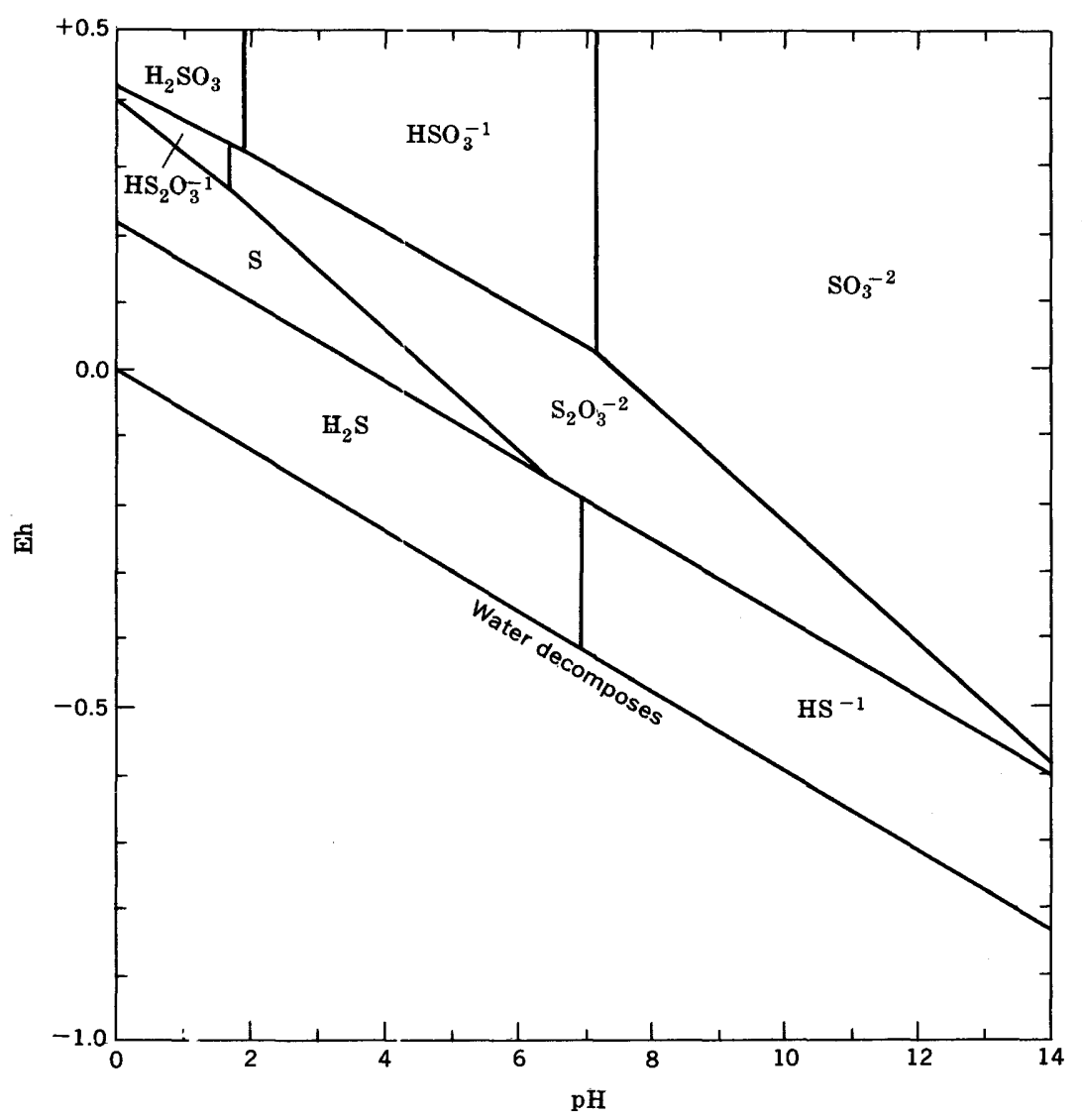

Figure 1. - Equilibrium distribution of unstable sulfur species in water. Total dissolved sulfur exclusive of sulfate species $=0.001 \mathrm{M}$ at $25^{\circ} \mathrm{C}$ and 1 atmosphere total pressure. From Granger and Warren (1969, p. 166).

Reproduced from Economic Geology, 1969, v. 64, p. 166.

Granger and Warren (1969, p. 166) constructed an Eh-pH diagram of the equilibrium distribution of unstable sulfur species in water by ignoring sulfate concentrations (fig. 1). Their interpretation shows that the thiosulfate ion is most likely to be found in near-neutral solutior s in equilibrium with $\mathrm{H}_{2} \mathrm{~S}$ and $\mathrm{SO}_{3}{ }^{-2}$. In acid solutions the thiosulfate ion disassociates into $\mathrm{S}^{\circ}$ and $\mathrm{HSO}_{3}{ }^{-1}$, and, as the solution approaches an alkaline $\mathrm{pH}$, the products become $\mathrm{HS}^{-1}$ and $\mathrm{SO}_{3}{ }^{-2}$. It should be kept in mind, however, that the stable states of sulfur in the acid oxidizing region are $\mathrm{H}_{2} \mathrm{~S}, \mathrm{~S}^{\circ}$ and $\mathrm{SO}_{4}^{--2}$, and in the alkaline region $\mathrm{HS}^{-1}$ and $\mathrm{SO}_{4}^{-2}$ (Garrels, 1960). Valensi (1963, p. 64) presented an equilibrium diagram similar to that of Granger and Warren and discussed the reactions in more detail. 
Garrels and Naeser (1958, p. 121, fig. 19) calculated the equilibrium distribution of dissolved sulfur species for $0.1 M$ total sulfur in water at $25^{\circ} \mathrm{C}$ and one atmosphere total pressure and found that the maximum concentration of $\mathrm{S}_{2} \mathrm{O}_{3}{ }^{-2}$ would be $10^{-6} \mathrm{M}$ or $0.11 \mathrm{ppm} \mathrm{S}_{2} \mathrm{O}_{3}{ }^{-2}$. This amount is the average value for 10 hot springs in Japan reported by Miyake $(1965$, p. 219). The fact of interest in this discussion is that the thiosulfate ion is a normal metastable form that could be found in the aqueous environment of sulfur and sulfur dioxide between $\mathrm{pH}$ of 2 to 9 ; an environment that can exist in the oxidation of sulfide ores. In an alkaline situation, such as postulated by Listova, Vainshtein, and Ryabinina (1966), thiosulfate may result from the reaction of $\mathrm{SO}_{3}{ }^{-2}$ and $\mathrm{HS}^{-1}$ produced by the oxidation of pyrite in the presence of limestone and, locally, it could reach concentrations adequate to dissolve gold.

\section{FORMATION OF GOLD THIOSULFATE}

The gold thiosulfate complex may be of importance in the transient solubility of gold in the weathering cycle. Listova, Vainshtein, and Ryabinina (1966) reported that, during air oxidation of sulfides of iron, lead, and zinc, gold was more soluble in a $\mathrm{CaCO}_{3}$ environment than in an acid medium. They suggested that calcium thiosulfate and polythionates, formed during the reaction of carbonates with the products of sulfide oxidation, are the solvents for gold. In spite of the transitory nature of the thiosulfate ion in an oxygenated solution, they reported that gold is retained in solution for a long time, and, therefore, such complexes have a large migration capacity.

During a 48-hour period Stetefeldt (1885, p. 50) dissolved $2 \mathrm{mg}$ of gold in a liter of $0.04 M \mathrm{Na}_{2} \mathrm{~S}_{2} \mathrm{O}_{3}$ solution containing $50 \mathrm{mg}$ of leaf gold. Increasing the concentration of $\mathrm{Na}_{2} \mathrm{~S}_{2} \mathrm{O}_{3}$ to $1 \mathrm{M}$ made no appreciable change in the amount of gold dissolved. The limiting factor apparently was the concentration of dissolved oxygen in the water rather than the thiosulfate concentration. In our laboratory $3 \mathrm{mg} / \mathrm{l}$ gold $(3 \mathrm{ppm})$ was dissolved in an $0.008 \mathrm{M}$ $\mathrm{Na}_{2} \mathrm{~S}_{2} \mathrm{O}_{3}$ solution in 1 week.

The metastable state of the thiosulfate ion and the relative rarity of the ion is compensated, in part, by the stability of the gold thiosulfate complex. At room temperature a solution of $\mathrm{Na}_{3} \mathrm{Au}\left(\mathrm{S}_{2} \mathrm{O}_{3}\right)_{2}$ does not yield the usual reaction for the thiosulfate ion - that is, dilute hydrochloric or sulfuric acids do not precipitate sulfur. In a like manner, gold as a thiosulfate complex is not reduced by stannous chloride, ferrous sulfate, or oxalic acid (Rose, 1898 , p. 31 ; Pascal, 1957, p. 732). The lack of loss of gold from 
solution in contact with various minerals (table 4) is another indication of the stability of the gold thiosulfate complex.

The solubility of leaf gold in dilute thiosulfate solutions (table 14) varies with the $\mathrm{pH}$ of the solution. At $\mathrm{pH} 5$ and greater, gold is appreciably soluble in a solution approximately 40 times as concentrated $(0.012 M$ versus $0.0003 M)$ as the maximum reported in Japanese waters (Miyake, 1965, p. 269). During the oxidation of pyrite in limestone adequate concentrations of thiosulfate may be reached to dissolve gold.

TABLE 14. - Solubility of leaj gold in 0.0124 M sodium thiosulfate solutions adjustıd to various $p H$ values

\begin{tabular}{|c|c|c|c|c|}
\hline \multirow{2}{*}{$\mathbf{p H}$} & \multirow{2}{*}{$\begin{array}{c}\mathrm{pH} \text { adjusted } \\
\text { with }-\end{array}$} & \multicolumn{3}{|c|}{ Gold $(\mathrm{ppm})$ in solution } \\
\hline & & After 7 days & After 14 days & After 21 days \\
\hline $2.54^{1}$ & dil $\mathrm{H}_{2} \mathrm{SO}_{4} \ldots \ldots$ & 0.28 & 0.46 & 0.8 \\
\hline 4.96 & .........do...................... & 1.1 & 2.2 & 3.7 \\
\hline 6.94 & $\mathrm{NaOH}$ & 1.1 & 2.6 & 3.3 \\
\hline 9.15 & ……....do..................... & .9 & 1.3 & 2.0 \\
\hline 10.53 & .........do & 1.3 & 2.2 & 3.0 \\
\hline
\end{tabular}

'Sulfur was precipitated at this pH, indicating partial decomposition of the thiosulfate.

The solubility of ore gold has also been determined in dilute sodium thiosulfate solutions adjusted to various $\mathrm{pH}$ values (table 15). Oxidized ores (samples EM-534-9-10 and C-2) yielded 10-12 percent of the gold content to solution in 3 weeks. Gold telluride (sample GBG 26) and auriferous pyrite (sample U-73) yielded 1-4 percent of the total gold to solution. With these materials, the initial solution was followed by loss of gold from solution, suggesting an increase in acidity with time and oxidation of the thiosulfate ion. The data on the auriferous jasperoid (sample D-344), showing a high maximum of 63 percent dissolved at $\mathrm{pH} 2.36$, are not understood by the authors.

In summary, gold is dissolved by dilute sodium thiosulfate solutions at $\mathrm{pH}$ values greater than 5 . The thiosulfate ion is present in environments high in sulfur content but generally in very low concentrations. Many bacteria oxidize thiosulfate and are present in most surficial environments. Gold thiosulfate is not appreciably absorbed by plants.

\section{GOID THIOCYANATE GEOCHEMISTRY OF THE THIOCYANATE ION}

Gold is readily dissolved in the presence of the thiocyanate ion, especially in acid solutions. It is, however, difficult to find any discussion of thiocyanates in geochemical or mineralogical literature except that of julienite, a hydrated sodium cobalt thiocyanate 
TABLE 15. - Solubility of ore gold in 0.0124 M sodium thiosulfate solution adjusted to various $p H$ values

\begin{tabular}{|c|c|c|c|c|c|c|}
\hline \multirow[b]{2}{*}{$\mathbf{p} \mathbf{H}$} & \multirow{2}{*}{$\begin{array}{c}\mathrm{pH} \text { adjusted } \\
\text { with }-\end{array}$} & \multicolumn{3}{|c|}{ Gold $(\mathrm{ppm})$ in solution } & \multirow{2}{*}{$\begin{array}{c}\text { Maximum } \\
\text { gold } \\
\text { dissolved } \\
(\mu g)\end{array}$} & \multirow{2}{*}{$\begin{array}{l}\text { Percentage o } \\
\text { gold dissolved } \\
\text { from ore }\end{array}$} \\
\hline & & $\begin{array}{l}\text { After } \\
7 \text { days }\end{array}$ & $\begin{array}{c}\text { After } \\
14 \text { days }\end{array}$ & $\begin{array}{c}\text { After } \\
\text { 21 days }\end{array}$ & & \\
\hline \multicolumn{7}{|c|}{ Sample No. EM-534-9-10. Gold $25 \mathrm{ppm}$} \\
\hline 5.7 & Not adjusted..... & 0.06 & 0.08 & 0.1 & 25 & 10 \\
\hline 2.35 & Diluted $\mathrm{H}_{2} \mathrm{SO}_{4} \ldots \ldots \ldots \ldots \ldots$ & .1 & .08 & .12 & 30 & 12 \\
\hline 4.10 & 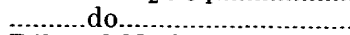 & .06 & .06 & .12 & 30 & 12 \\
\hline 10.28 & Diluted $\mathrm{NaOH}$ solution.. & .04 & $<.04$ & .06 & 15 & 6 \\
\hline \multicolumn{7}{|c|}{ Sample No. GBG26. Gold $162 \mathrm{ppm}$} \\
\hline 9.14 & Not adjusted.... & 0.24 & 0.08 & 0.12 & 60 & 3.7 \\
\hline 2.6 & Diluted $\mathrm{H}_{2} \mathrm{SO}_{4} \ldots \ldots \ldots \ldots \ldots$ & .08 & $<.04$ & $<.04$ & 20 & 1.2 \\
\hline 4.9 & ..................................... & .08 & $<.04$ & $<.04$ & 20 & 1.2 \\
\hline 10.6 & Diluted $\mathrm{NaOH}$ solution.. & .2 & .3 & .2 & 75 & 4.6 \\
\hline
\end{tabular}

Sample No. C-2. Gold $120 \mathrm{ppm}$

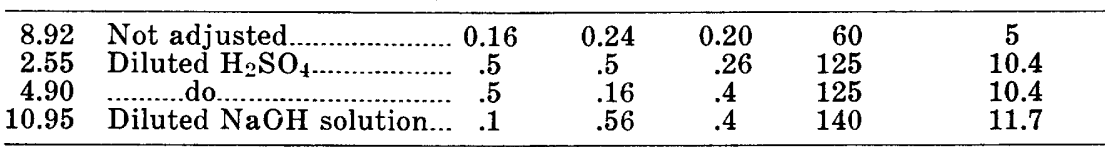

Sample No. U73. Gold $92 \mathrm{ppm}$

\begin{tabular}{|c|c|c|c|c|c|}
\hline $\begin{array}{l}4.63 \\
2.60 \\
7.10 \\
9.80\end{array}$ & 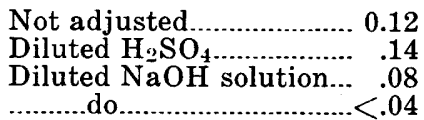 & $\begin{array}{l}<0.04 \\
<.04 \\
<.04 \\
<.04\end{array}$ & $\begin{array}{l}<0.04 \\
<.04 \\
<.04 \\
<.04\end{array}$ & $\begin{array}{l}30 \\
35 \\
20 \\
<.04\end{array}$ & $\begin{array}{l}3.2 \\
3.8 \\
2.2 \\
\cdots .\end{array}$ \\
\hline
\end{tabular}

\begin{tabular}{|c|c|c|c|c|c|}
\hline \multicolumn{6}{|c|}{ Sample No. D344. Gold $130 \mathrm{ppm}$} \\
\hline 9.30 & Not adjusted.. & 0.3 & 0.14 & 35 & 2.7 \\
\hline 2.36 & Diluted $\mathrm{H}_{2} \mathrm{SO}_{4} \ldots \ldots \ldots \ldots \ldots \ldots \ldots$ & 2.2 & 3.3 & 825 & 63 \\
\hline 4.90 & .........do & .5 & .32 & 100 & 7.7 \\
\hline 10.60 & Diluted $\mathrm{NaOH}$ solution... .12 & .06 & .08 & 30 & 2.3 \\
\hline
\end{tabular}

SAMPLE DESCRIPTIONS

EM-534-9-10. Fines from bedrock crevices at bottom of soil profile from Empire, Colo. Native gold with no observed sulfides. Bedrock is biotite gneiss containing only $0.04 \mathrm{ppm}$ gold.

GBG26. Volcanic breccia of phonolite-latite composition containing gold telluride and minor antimony and silver, SW $1 / 4$ sec. 20 , T. 15 N., R. 69 W., Cripple Creek district, Teller County, Colo. Collected by A. H. Koschmann and obtained from G. B. Gott.

C-2. Silicified carbonaceous dolomitic limestone, minor sulfides, arsenic, and mercury from Carlin gold mine, Lyman district, Eureka County, Nev. Collected by Ralph L. Erickson.

U73. Massive pyrite from vein in the Tenth Legion mine, Empire district, Clear Creek County, Colo. Collected by Maurice Chaffee.

D344. Massive gray jasperoid replacing dolomite; minor pyrite and hematite. Sec. 26, T. 14 S., R. 11 W., Drum Mountains, Juab County, Utah. Collected by J. H. MeCarthy, Jr.

mineral which has been found with cobaltian wad in a white schist at Chamibumba, near Kambove, Katanga, Belgian Congo (Palache and others, 1951). One must turn to the literature on biochemistry to find any other discussion of thiocyanates. White, Handler, Smith, and Stetten $(1959$, p. 876$)$ stated: "Thiocyanate is widely distributed in nature and occurs normally in blood, saliva, and the urine. Thiocyanate occurs in appreciable concentrations in many plants, such as members of the Brassica genus (cabbages) and Umbelliferae (carrot family). Of added significance is the occurrence of substances which may be transformed into thiocyanates 
by the mammalian organism. These include the isothiocyanates, such as mustard oil, the organic nitrites, and the widely distributed cyanogenetic glycosides." Perhaps the most convincing evidence for the existence of thiocyanate in nature is the organism Thiobacillus thiocyanoxidans which obtains its energy by oxidation of thiocyanate to sulfate, carbonate, and ammonia - its growth on organic media is not observed unless thiocyanate is present (Zajic, 1969, p. 59).

\section{FORMATION OF GOLD THIOCYANATE}

The relatively low oxidation potential for gold in the presence of the thiocyanate ion (table 1) suggests that dissolved oxygen in water would be an adequate oxidant. That this is true is illustrated in data on the solution of leaf gold in $0.1 M$ thiocyanate solutions adjusted to various $\mathrm{pH}$ values (table 16). Solution of the gold was greatest at $\mathrm{pH} 2.5$ but was not particularly impressive at any $\mathrm{pH}$.

A similar experiment with four gold ores showed the same response to $\mathrm{pH}$ (table 17). Much of the gold (42-66 percent) was dissolved from ores containing free native gold, but gold in massive pyrite and in gold telluride was not attacked.

TABLE 16. - Solubility of leaj gold in $0.1 \mathrm{M}$ potassium thiocyanate solutions adjusted to various $p H$ values

\begin{tabular}{lccc}
\hline pH & \multicolumn{3}{c}{ Dissolved gold (mg/l) } \\
\cline { 2 - 4 } & $\begin{array}{c}\text { After } \\
7 \text { days }\end{array}$ & $\begin{array}{c}\text { After } \\
14 \text { days }\end{array}$ & $\begin{array}{c}\text { After } \\
\text { 21 days }\end{array}$ \\
\hline 2.5 & 0.3 & 0.7 & 1.0 \\
5 & .14 & .34 & .4 \\
7 & $<.04$ & 0 & .2 \\
9 & $<.04$ & .08 & .16 \\
\hline
\end{tabular}

Potassium thiocyanate in various concentrations was added to the average input and pregnant leach solutions similar to those used in the leaching and recovery of copper in Southwestern United States porphyry copper deposits (table 18). The $\mathrm{pH}$ was varied from 2.5 to 9 , although the ferric iron was precipitated at $\mathrm{pH}$ of 5 through 9. The data show that the solution of gold in the $\mathrm{pH} 2.5$ solutions is considerable and that it is a function of the concentration of ferric iron and thiocyanate. It is interesting, perhaps, to note that the presence of as little as $0.0001 M$ thiocyanate ion in both the input (low ferric ion concentration) and pregnant (high ferric ion concentration) solutions resulted in the solution of $2 \mathrm{mg} / \mathrm{l}$ gold during a period of 2 weeks. This amounts to the solution of 0.24 ounce gold per 1,000 gallons of leach solution to which has been added only 1 ounce of sodium 
TABLE 17. - Solubility of ore gold in $0.1 \mathrm{M}$ potassium thiocyanate solutions adjusted to various $p H$ values

\begin{tabular}{|c|c|c|c|c|c|}
\hline \multirow{2}{*}{$\underset{\mathbf{p H}}{\text { Adjusted }}$} & \multicolumn{3}{|c|}{ Dissolved gold (mg/l) } & \multirow{2}{*}{$\underset{(\mu g)}{\underset{\text { Missolvimum gold }}{\text { Maximum }}}$} & \multirow{2}{*}{$\begin{array}{l}\text { Percentage of gold } \\
\text { dissolved from ore }\end{array}$} \\
\hline & $\begin{array}{l}\text { After } \\
7 \text { days }\end{array}$ & $\begin{array}{l}\text { After } \\
14 \text { days }\end{array}$ & $\begin{array}{l}\text { After } \\
\text { 21 days }\end{array}$ & & \\
\hline \multicolumn{6}{|c|}{ Sample No. EM-534-9-10. Gold 25 ppm } \\
\hline $\begin{array}{l}2.5 \\
5 \\
7 \\
9\end{array}$ & $\begin{array}{r}0.24 \\
.06 \\
.08 \\
<.04\end{array}$ & $\begin{array}{r}0.6 \\
.3 \\
.2 \\
.1\end{array}$ & $\begin{array}{l}0.66 \\
.32 \\
.2 \\
.1\end{array}$ & $\begin{array}{r}165 \\
80 \\
50 \\
25\end{array}$ & $\begin{array}{l}66 \\
32 \\
20 \\
10\end{array}$ \\
\hline \multicolumn{6}{|c|}{ Sample No. GBG26. Gold 162 ppm } \\
\hline $\begin{array}{l}2.5 \\
5 \\
7 \\
9\end{array}$ & $\begin{array}{r}<0.04 \\
<.04 \\
<.04 \\
<.04\end{array}$ & $\begin{array}{r}0.16 \\
.12 \\
.10 \\
.08\end{array}$ & $\begin{array}{r}0.12 \\
.12 \\
.10 \\
.06\end{array}$ & $\begin{array}{l}40 \\
30 \\
25 \\
20\end{array}$ & $\begin{array}{l}2.4 \\
1.8 \\
1.5 \\
1.2\end{array}$ \\
\hline \multicolumn{6}{|c|}{ Sample No. U75. Gold 79 ppm } \\
\hline $\begin{array}{l}2.5 \\
5 \\
7 \\
9\end{array}$ & $\begin{array}{r}<0.04 \\
<.04 \\
<.04 \\
<.04\end{array}$ & $\begin{array}{r}<0.04 \\
<.04 \\
<.04 \\
<.04\end{array}$ & $\begin{array}{r}<0.04 \\
<.04 \\
<.04 \\
<.04\end{array}$ & $\begin{array}{l}0 \\
0 \\
0 \\
0\end{array}$ & $\begin{array}{l}0 \\
0 \\
0 \\
0\end{array}$ \\
\hline \multicolumn{6}{|c|}{ Sample No. D344. Gold 130 ppm } \\
\hline $\begin{array}{l}2.5 \\
5 \\
7 \\
9\end{array}$ & $\begin{array}{c}1.9 \\
.2 \\
.2 \\
.14\end{array}$ & $\begin{array}{r}2.2 \\
.6 \\
.5 \\
.5\end{array}$ & $\begin{array}{r}2.2 \\
.6 \\
.6 \\
.6\end{array}$ & $\begin{array}{l}550 \\
150 \\
150 \\
150\end{array}$ & $\begin{array}{l}42.3 \\
11.5 \\
11.5 \\
11.5\end{array}$ \\
\hline
\end{tabular}

SAMPLE DESCRIPTIONS

EM-534-9-10. Fines from bedrock crevices at bottom of soil profile from Empire, Colo. Native gold with no observed sulfides. Bedrock is biotite gneiss containing only $0.04 \mathrm{ppm}$ gold.

GBG26. Volcanic breccia of phonolite-latite composition containing gold telluride and minor antimony and silver. SW $1 / 4$ sec. 20, T. 15 N., R. 69 W., Cripple Creek district, Teller County, Colo. U75. Massive pyrite from dump of Atlantic shaft, Empire district, Clear Creek County, Colo. D344. Massive gray jasperoid replacing dolomite; minor pyrite and hematite. Sec. 26, T. 14 S.,

R. 11 W., Drum Mountains, Juab County, Utah. Collected by J. H. McCarthy, Jr.

thiocyanate. The marked mobility of gold thiocyanate observed in experiments with 114 minerals and rocks (table 4) combined with the solubility of gold in acid thiocyanate solutions makes this an attractive complex. The presence of the microorganism, Thiobacillus thiocyanoxidans, however, would make difficult to impossible the retention of even this low $(0.0001 M)$ concentration of thiocyanate in the system.

\section{GOLD CYANIDE GEOCHEMISTRY OF THE CYANIDE ION}

Naturally occurring cyanides have their origin in biosystems. Some 70 years ago Lungwitz $(1900$, p. 501) speculated on the possibility of cyanide being the complex that carried gold in solution and into plants. He abandoned cyanide as a possibility because he could not find any evidence of its being formed in the decomposition of plant residues. He did maintain that vegetation 
TABLE 18. - The interactions of the concentration of $\mathrm{CNS}^{-1}$ and $\mathrm{H}^{+1}$ on the solubility of gold in copper leach solutions

\begin{tabular}{|c|c|c|c|c|c|c|c|c|c|c|c|c|c|}
\hline \multicolumn{2}{|c|}{$\begin{array}{l}\text { Average porphyry copper } \\
\text { leach solutions }\end{array}$} & \multicolumn{6}{|c|}{ 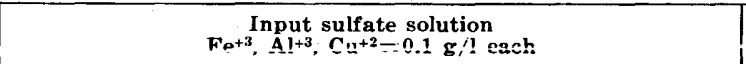 } & \multicolumn{6}{|c|}{ 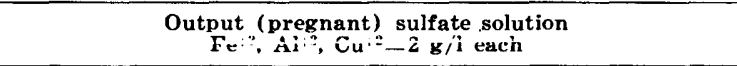 } \\
\hline $\begin{array}{l}\text { Add } \\
\text { CNS } \\
\text { as KCNS }\end{array}$ & $\left\{\begin{array}{c}\text { Normality } \\
\text { of } \\
\text { CNS }^{-1} \text {. } \\
\text { ppm of }_{\text {CNS }}^{-1}\end{array}\right.$ & $\begin{array}{l}0.0001 \\
5.8\end{array}$ & $\begin{array}{l}0.0005 \\
29\end{array}$ & $\begin{array}{l}0.001 \\
58\end{array}$ & 0.005 & 0.01 & 1160 & $\begin{array}{l}0.0001 \\
5.8\end{array}$ & 0.0005 & $\begin{array}{l}0.001 \\
58\end{array}$ & 0.005 & 0.01 & 1160 \\
\hline \multicolumn{14}{|c|}{ Parts per million of gold in solution after 2 weeks of contact with gold } \\
\hline 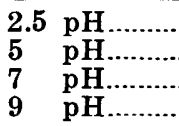 & - & $\begin{array}{r}1.9 \\
.3\end{array}$ & $\begin{array}{r}7.7 \\
.5\end{array}$ & $\begin{array}{r}12.8 \\
.4 \\
0 . .6 \\
\end{array}$ & $\begin{array}{r}29 \\
8.1 \\
1.5 \\
.4\end{array}$ & $\begin{array}{r}38.7 \\
18.7 \\
1.2 \\
.6\end{array}$ & $\begin{array}{r}84.7 \\
48.4 \\
4.6 \\
1.0\end{array}$ & \begin{tabular}{|r|}
2.0 \\
.3
\end{tabular} & $\begin{array}{r}8.8 \\
.5\end{array}$ & $\begin{array}{r}13.6 \\
.7\end{array}$ & $\begin{array}{c}36 \\
2.4 \\
.2 \\
.08\end{array}$ & $\begin{array}{c}73 \\
13 \\
1.5 \\
.2\end{array}$ & $\begin{array}{c}104 \\
19 \\
1.7 \\
.5\end{array}$ \\
\hline
\end{tabular}


must be responsible for the solubility of gold in surface waters and left the identification of cyanide in vegetable residues to future researches. By now, hundreds of reports have been published showing that plants, fungi, and arthropods produce cyanoglycosides, which on decomposition yield hydrogen cyanide. Perhaps it is now appropriate to consider, as Lungwitz did, the possibility that the cyanide complex of gold is the effective mobile form of gold in soils.

Twenty years after the discovery of hydrocyanic acid, Bohn (in Dillemann, 1959, p. 1050) in 1801 isolated cyanides from an aqueous distillate of Prunus amygdus. Amygdalin was crystallized in a pure state in 1830, a cyanoglycoside that is hydrolyzed by an enzyme to two molecules of glucose, one molecule of benzaldehyde, and one molecule of hydrogen cyanide (Dillemann, 1959, p. 1050; Armstrong and Armstrong, 1931, p. 68). The toxic character of cyanoglycosides was known to the early Egyptians who prepared a poisonous liquor by boiling peach leaves in water (Latimer and Hildebrand, 1951, p. 296).

Hydrogen cyanide derived from plant tissue is a product of the hydrolysis of glycosides containing a nitrile group. Eleven naturally occurring cyanoglycosides have been identified (Conn and Butler, 1969, p. 47). Plants containing cyanoglycosides also contain enzymes that hydrolyze the glycoside. These enzymes are separated from the cyanoglycosides by cell walls, however, so that hydrolysis and formation of hydrogen cyanide occurs when the plant is damaged or dies. The enzymes listed in table 19 are probably mixtures of enzymes rather than a single species. Thus, in the hydrolysis of linamarin, a $\beta$-glucosidase hydrolyzes the glycoside to cyanohydrin and sugar, and this reaction is followed by the catalytic action of oxynitrilase to yield acetone and hydrogen cyanide.

Plants producing cyanogenic glycosides are of common occurrence. About 1,000 species, representing 90 plant families and

TABLE 19. - Some cyanoglycosides, associated enzyme source, and hydrolysis products

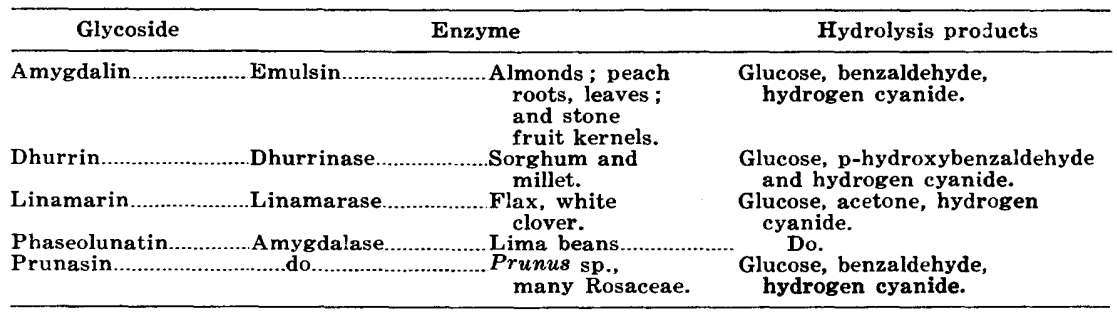


about 250 genera, produce cyanogenic glycosides. Because of the toxic qualities of these plants, detailed studies have been given to plants of agricultural importance. Thus, sorghum (Sorghum vulgare) produces the cyanogenic glycoside dhurrin and the enzyme dhurrinase, which hydrolyzes the glycoside to give hydrogen cyanide as one of the products of hydrolysis. A large number of sorghum varieties are grown in the United States, and their toxicity is variable. Couch, Briese, and Martin $(1939$, p. 160, 161) examined 33 sorghum varieties grown at one or more of six localities in the Great Plains and found that all of them contain from 12 to $75 \mathrm{mg} \mathrm{HCN} / 100 \mathrm{~g}$ - sufficient to be toxic to animals. Although the amount of hydrogen cyanide liberated by sorghums is a function of the variety and of the seasonal climate, perhaps a more important factor is the amount of the enzyme dhurrinase produced by the plant. Only a slow evolution of hydrogen cyanide was determined in many samples of sorghum, found deficient in dhurrinase (Couch and Briese, 1940, p. 419).

The cyanoglycoside content of a plant varies with the season and with the plant part. In 2-year-old peach seedlings, the amygdalin content is greater in the leaves than in the branches and twigs and is highest in the roots. Trees sampled in the fall of the year had a higher concentration of amygdalin in the above-ground parts and a lower concentration in the roots than those sampled in the spring (Ward and Durkee, 1956, p. 421). Patrick (1955, p. 467) observed that certain microorganisms in the soil utilized the amygdalin from peach tree roots with liberation of hydrogen cyanide.

Varieties of flax differ markedly in their susceptibility to Fusarium wilt (a disease caused by Fusarium lini), and their susceptibility is an inverse function of their linamarin content. The excretion of significant quantities of hydrogen cyanide, the byproduct of hydrolysis of linamarin, into the soil from the root system of the resistant varieties of flax creates unfavorable conditions for the growth of Fusarium lini. The resistant flax plants generated as much as 25.3 to $37.6 \mathrm{mg}$ HCN per plant when grown in nutrient solution (Timonin, 1941, p. 404).

Although the fungus Fusarium lini is susceptible to poisoning by hydrogen cyanide, Marasmius oreades, a fairy-ring fungus, produces cyanogenic compounds that damage the roots of Festuca rubra (red fescue), Poa pratensis (Kentucky bluegrass), and Agrostis tenuis (colonial bent). The absorption of hydrogen cyanide in $5 \mathrm{ml}$ of sodium picrate solution suspended above a 52-dayold culture of the fungi amounted to 50 to $70 \mathrm{ppm}$, or 0.25 to 
$0.37 \mathrm{mg}, \mathrm{HCN}$ each 24 hours. Hydrogen cyanide was also detected above soil infested with the fungi (Filer, 1965, p. 574).

Aposematic (having special means of defense) species of millipedes, such as Apheloria corrugata (Wood) and Pachydesmus crassiculis (Wood), excrete a defensive fluid containing hydrogen cyanide and benzaldehyde (Blum and Woodring, 1962, p. 512; Eisner and others, 1963 , p. 1219). The secretion is discharged from paired serially arranged glands. Each gland contains two compartments - an undissociated cyanogenic compound is stored in one compartment and a catalytic compound is stored in the other compartment. When disturbed the animal excretes the contents of both compartments and hydrolysis is initiated at the instant of discharge (Eisner and others, 1963, p. 1218).

Hydrocyanic acid is released from crushed tissues of all stages in the life-cycle of species of Zygaeninal (burnets and foresters moths). The pupae and freshly emerged specimens of these aposematic moths release up to 0.2 percent $\mathrm{HCN}$ on a fresh weight basis and about 4 percent HCN from the crushed eggs (Jones and others, 1962, p. 53).

In summary, many organisms produce compounds that yield hydrogen cyanide on hydrolysis, including species of plants, fungi, and animals. Reviews of the voluminous literature are given by Conn (1969), Dillemann (1959), and Tschiersch (1967).

\section{FORMATION OF GOLD CYANIDE}

Both the foregoing and the information given in the section on tests for cyanide in some native and naturalized plants by H. T. Shacklette demonstrate that hydrogen cyanide can frequently be present in soils in concentrations adequate to facilitate the solution of gold. Further, data given in another section indicate that the gold cyanide produced in soils is likely to be taken up by plants.

We have dissolved leaf gold in suspensions of macerated flax, peach roots, mountain-ash, chokecherry, desert apricot, and mountain mahogany (tables 20,21 ). We have also dissolved 10 percent of the gold in $25 \mathrm{~g}$ of a subsoil (EM-534-8-9, $30 \mathrm{ppm}$ gold) immersed for 5 days in $250 \mathrm{ml}$ of water at $\mathrm{pH} 7.5$ containing $10 \mathrm{~g}$ of macerated peach roots (table 21). The addition of the enzyme emulsin sufficient to assure the hydrolysis of the amygdalin in the peach roots did not appreciably increase the solution of gold.

Although the gold cyanide complex may be present in soils and may be relatively mobile, as shown both by its ready entrance into plant cells (table 6) and by the low percentage of rocks or ore minerals that significantly removed gold cyanide from solution 
TABLE 20. - Solution of leaf gold by native cyanogenic plants macerated in plant/water slurries

[Plants identified by H. T. Shacklette]

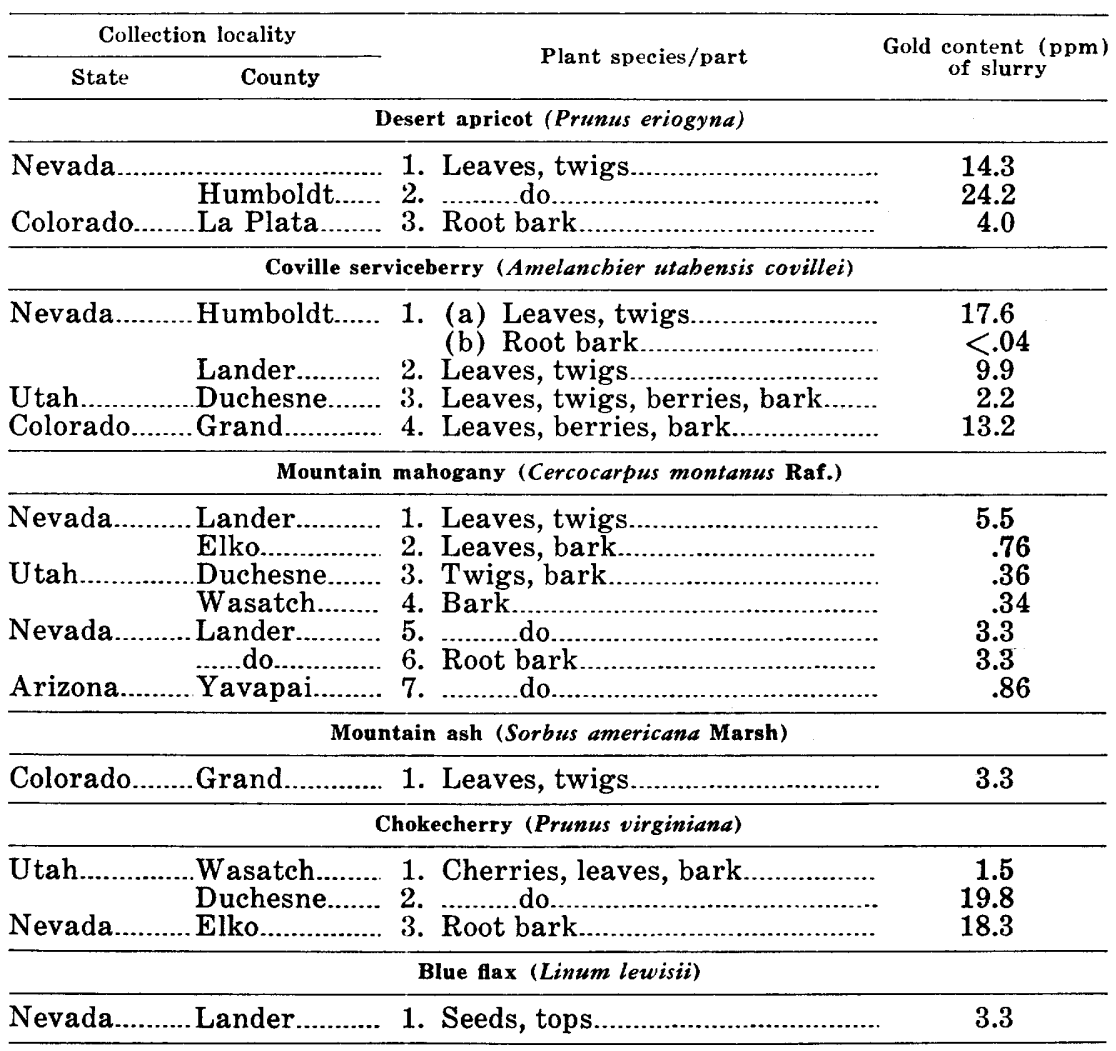

TABLE 21. - Solubility of gold in slurries of macerated peach roots, macerated peach roots plus emulsin, and in emulsin-plus-water mixtures

[Gold values in parts per million; $\mathrm{pH}$ is $5.5 \pm 0.5$ ]

\begin{tabular}{lccccc}
\hline & \multirow{2}{*}{$\begin{array}{c}\text { Demineralized } \\
\text { water }\end{array}$} & \multicolumn{2}{c}{$\begin{array}{c}\text { Macerated peach } \\
\text { roots slurry }\end{array}$} & \multicolumn{2}{c}{ Emulsin + water } \\
\cline { 3 - 6 } & $10 \mathrm{~g}$ & $10 \mathrm{~g}+$ emulsin & $10 \mathrm{~g}$ & $50 \mathrm{~g}$ \\
\hline $\begin{array}{l}\text { Leaf gold................... } \\
\text { Particulate }\end{array}$ & 45.6 & 31.5 & $<0.02$ & $<0.02$ \\
$\begin{array}{l}\text { gold in } \\
25\end{array}$ & & & & & \\
\hline
\end{tabular}

(table 4), one must not assume a state of lasting mobility. The cyanide ion is itself a transient component of soils. It is hydrolyzed by acid or alkaline solutions. The reaction of $\mathrm{CN}^{-1}+2 \mathrm{H}_{2} \mathrm{O} \rightarrow \mathrm{NH}_{3}$ $+\mathrm{HCO}_{2}{ }^{-1}$ goes to completion at $140^{\circ} \mathrm{C}$ in dilute hydrochloric acid. At ambient soil temperatures and $\mathrm{pH}$ the reaction would be 
expected to proceed slowly. In the presence of a catalyst the hydrolysis of $\mathrm{CN}^{-1}$ could be rapid. Certain parasites produce the enzyme rhodanase, which catalyzes the reaction of $\mathrm{CN}^{-1}$ with $\mathrm{S}^{\circ}$ or $\mathrm{S}_{2} \mathrm{O}_{3}{ }^{-2}$ to produce $\mathrm{CNS}^{-1}$. Rhodanase is widely distributed in nature (Jones and others, 1962, p. 53). Rhodanase in the liver catalyzes sulfur transfer from mercaptopyruvate to cyanide to form thiocyanate $\left(\mathrm{CNS}^{-1}\right)$ and pyruvate. In the normal decomposition of plant and animal residues, it is to be expected that organisms will be present and capable of destroying cyanides.

In conclusion, ample hydrogen cyanide is formed in the soil by hydrolysis of cyanogenic plants, animals, and fungi - to result in solution of gold in an oxygenated environment. The gold cyanide thus formed is absorbed by plants. This process provides a definite pathway for the migration of gold in soils. The ready decomposition of the cyanide radical by hydrolysis and by enzymic alteration limits the mobility of gold cyanide.

\section{TESTS FOR CYANIDE IN SOME NATIVE AND NATURALIZED PLANTS OF THE UNITED STATES}

BY HANSFord T. SHACKLETTE

Plants were sampled along highways and in mining districts on a route extending from the Front Range of the Rocky Mountains to north-central Nevada, west-central Arizona, north-central New Mexico, and southwestern Colorado (fig. 2) to determine the abundance of plant species that are cyanogenic and can, therefore, potentially influence the geochemical mobility of gold. Some additional species were sampled at scattered locations throughout the United States. A wide variety of native and naturalized plants were included for the purpose of testing cyanide in members of plant families that were known to contain many cyanogenic species (for example, the rose family, Rosaceae), as well as species in families not known to have cyanogenic tendencies. The species that were invariably cyanogenic were soon discovered; thereafter, the testing was restricted mostly to these species in different locations that were known or suspected to have anomalous amounts of gold in the substrates. The climate at many of these locations was so dry that only sparse vegetation was present, but testing was extended to these sites to determine if cyanogenic plants formed a significant part of this vegetation.

Field studies were made during the latter half of August and the first week in September of 1969, a season when the weather is generally hot and dry at most of the study locations. The type of vegetation present at each study site was noted by using the method of classification and the mapped distribution of potential 

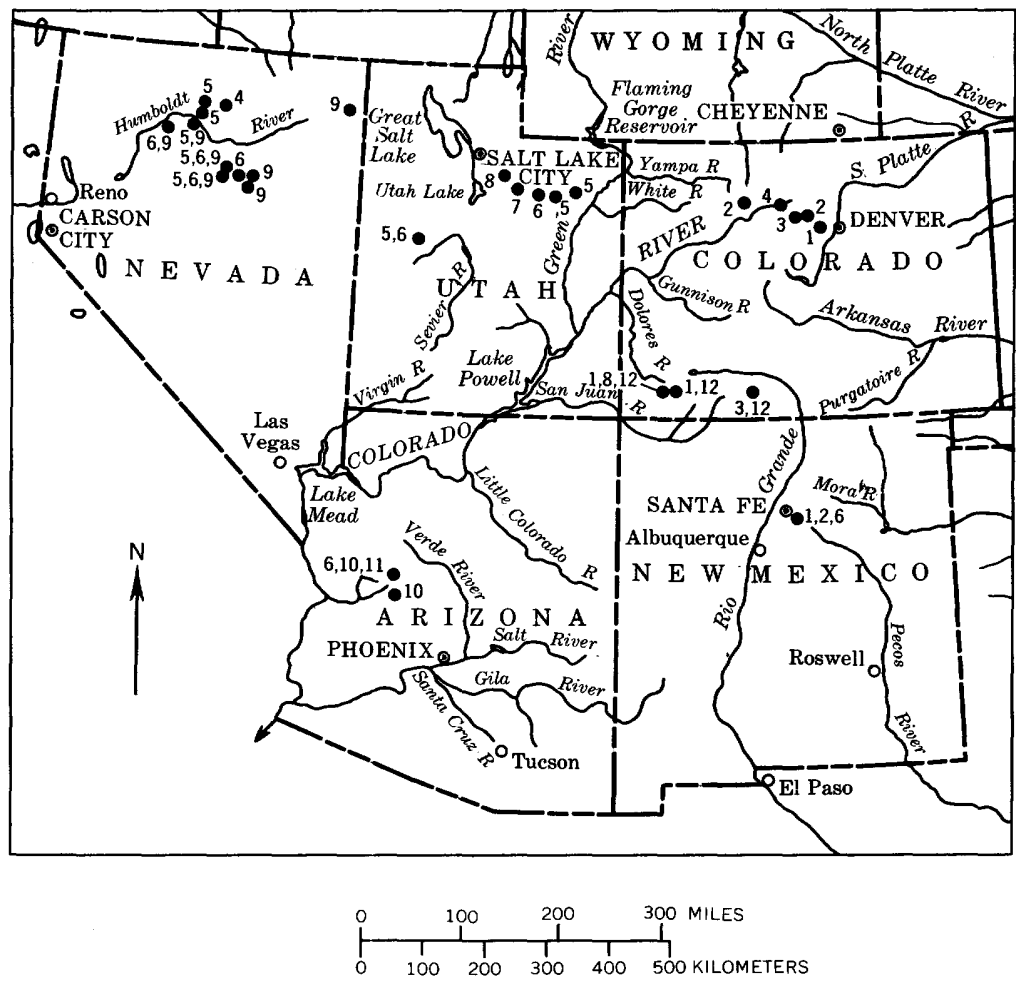

VEGETATION TYPE

\author{
1. Pine-Douglas-fir forest \\ 2. Western spruce-fir forest \\ 3. Alpine meadows and barren \\ 4. Sagebrush steppe \\ 5. Saltbush-greasewood \\ 6. Juniper-piñon woodland
}

7. Douglas-fir forest
8. Mountain mahogany-oak scrub
9. Great Basin Sagebrush
10. Grama-tobosa shrub steppe
11. Chaparral
12. Southwestern spruce-fir forest

FIGURE 2. - Location of sites where plants were sampled for cyanide testing, and the vegetation type or types present at the sites.

natural vegetation as given by Küchler (1964; fig. 2 ). Reference specimens of the species to be tested for cyanide were identified and later preserved in a U.S. Geological Survey herbarium in Denver.

The plant samples for cyanide testing included stems, stem bark, leaves; roots, root bark, flowers, fruits, or the entire plant, as was appropriate for the species. Most samples were tested at the sites where they were collected by using facilities provided in a mobile laboratory. The samples were macerated in test tubes with a narrow stainless steel spatula or with a knife blade. A few drops of chloroform were added to the macerated material, then a strip of picric-acid paper was suspended in the test tube by means of a tight-fitting cork. The prepared samples were kept in a warm 
place for 24 hours before the color reactions of the test papers were noted. The samples were prepared and tested for cyanide by H. W. Lakin, G. C. Curtin, and C. W. Gale III.

The picric-acid test paper was prepared and calibrated in the U.S. Geological Survey laboratories in Denver before field studies were undertaken. Discs of filter paper were dipped in a solution of 1 percent picric acid and 10 percent sodium carbonate, then dried, cut into strips, and the strips stored in a tightly corked bottle. These strips were calibrated for their color reactions when suspended over potassium cyanide solution of different concentrations, as shown in table 22 .

TABLE 22. - Approximate cyanide concentrations in solutions, as indicated by color reactions of picric-acid paper suspended over the solutions

\begin{tabular}{|c|c|c|}
\hline $\begin{array}{c}\text { Cyanide concentrations } \\
\text { (in ppm) in the } \\
\text { solutions }\end{array}$ & $\begin{array}{l}\text { Color reactions } \\
\text { produced }\end{array}$ & $\begin{array}{l}\text { Interpretations of color as an } \\
\text { indicator of HCN (hydrogen } \\
\text { cyanide) concentrations }\end{array}$ \\
\hline 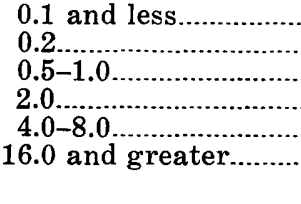 & 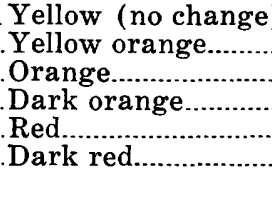 & $\begin{array}{l}\text { Negative }(-1) \\
\text { HCN possibly present }(+1 \text { ? }) \\
\text { Positive presence of } \mathrm{HCN}(+1) \\
\text {.Strong positive }(+2) \\
\text {.Very strong positive }(+3) \\
\text { Maximum color reaction, } \\
\text { reagent consumed }(+4) \text {. }\end{array}$ \\
\hline
\end{tabular}

Results of the cyanide tests are given in table 23. One or more parts of 150 species, distributed among 49 plant families, were tested. Among these species the distribution of approximate cyanide concentrations in 186 samples of one or more plant parts, as classified in table 22, is as follows : No HCN detected, 127 samples; HCN possibly present, 17 samples; positive presence of HCN $(0.5-1 \mathrm{ppm}), 11$ samples; strong positive $(2 \mathrm{ppm}), 11$ samples; very strong positive $(4-8 \mathrm{ppm}), 15$ samples; and maximum color reaction (16 ppm and greater), 5 samples. In summary, of the 150 species tested, 116 species ( 78 percent) contain no detectable HCN in any part sampled, 15 species (10 percent) possibly contain low concentrations of $\mathrm{HCN}$ in at least some parts, and 19 species (12 percent) positively contain $\mathrm{HCN}$ in one or more of their parts.

The cyanogenic ability of some members of the rose family (Rosaceae) was confirmed by our studies; furthermore, positive tests for cyanide were obtained of some species in this family in all but two vegetation types. The important cyanogenic woody plants in the Rocky Mountains are wild plum, chokecherry, mountain-ash, mountain mahogany (Cercocarpus montanus), and smooth shadbush, whereas in the Basin and Range province mountain mahogany (Cercocarpus ledifolius), desert peach, chokecherry, cliffrose, 
and Utah shadbush were of common occurrence. Judged from the nature of their habitats, these trees and shrubs probably have extensive and deep-penetrating roots. If these roots tend to secrete hydrogen cyanide to the extent reported for flax roots (Timonin, 1941, p. 407), large amounts (but probably low concentrations) of this compound are available to solubilize gold that may be in the soil near them.

Wild flax (family Linaceae) was the only herbaceous plant tested that invariably contained significant concentrations of cyanide. The blue-flowered flaxes (Linum usitatissimum and $L$. lewisii) produce hydrogen cyanide abundantly, whereas this compound was not detected in samples of the yellow-flowered flax (Linum medium var. texanum). Wild flax is widespread in the regions studied, but, compared with trees and shrubs, it probably is of only minor importance in adding cyanide to the soil because of its small root systems. Tests of herbaceous plants in other families indicated that either no cyanide or a very low concentration of cyanide is contained in these herbs. Tests of stonecrop (Sedum stenopetalum, family Crassulaceae), an herb, were inconclusive; usually no cyanide was found, but tests of some samples that included roots of the plant indicated that cyanide possibly was present. Profuse growths of mycorrhiza commonly surround these roots, and the cyanide that apparently was found may have been produced by the fungal mycelia. Cyanide was not found in Marchantia polymorpha (family Marchantiaceae), the only bryophyte that was tested.

Species of cyanogenic plants occur in most of the vegetation types listed in figure 2. The extent of these types in the United States was mapped by Küchler (1964). The areas not examined in the present study can be evaluated for the probable occurrence of cyanogenic species by extrapolating the following records of these species in the various vegetation types onto Küchler's vegetation map. Some vegetation types too small in extent to be indicated on this map occur within the major vegetation areas, therefore some species in the following list are not characteristic species of the vegetation types under which they are listed. Some nondominant species reported in a particular vegetation type do not necessarily occur throughout the range of that type. The questionable cyanogenic species are listed as " $(+1$ ?)."

1. Pine-Douglas-fir forests - Mountain mahogany (Cercocarpus montanus), wild plum, smooth shadbush, chokecherry, wild flax, red-berried elder $(+1$ ?), stonecrop $(+1$ ?), columbine $(+1$ ?), and Rocky Mountain clematis $(+1$ ?). 
TABLE 23. - Results of tests for hydrocyanic acid (HCN) in selected species of plants

[Results are expressed as color reactions of picric acid paper to macerated plant parts as follows : Yellow, negative ( -1$)$ test; yellow-orange, HCN possibly present $(+1$ ?) ; orange, positive presence of $\mathrm{HCN}(+1)$; dark orange, strong positive $(+2)$; red, very strong positive $(+3)$; dark red, maximum color . Sp. indet., species not determined. Common names of plants

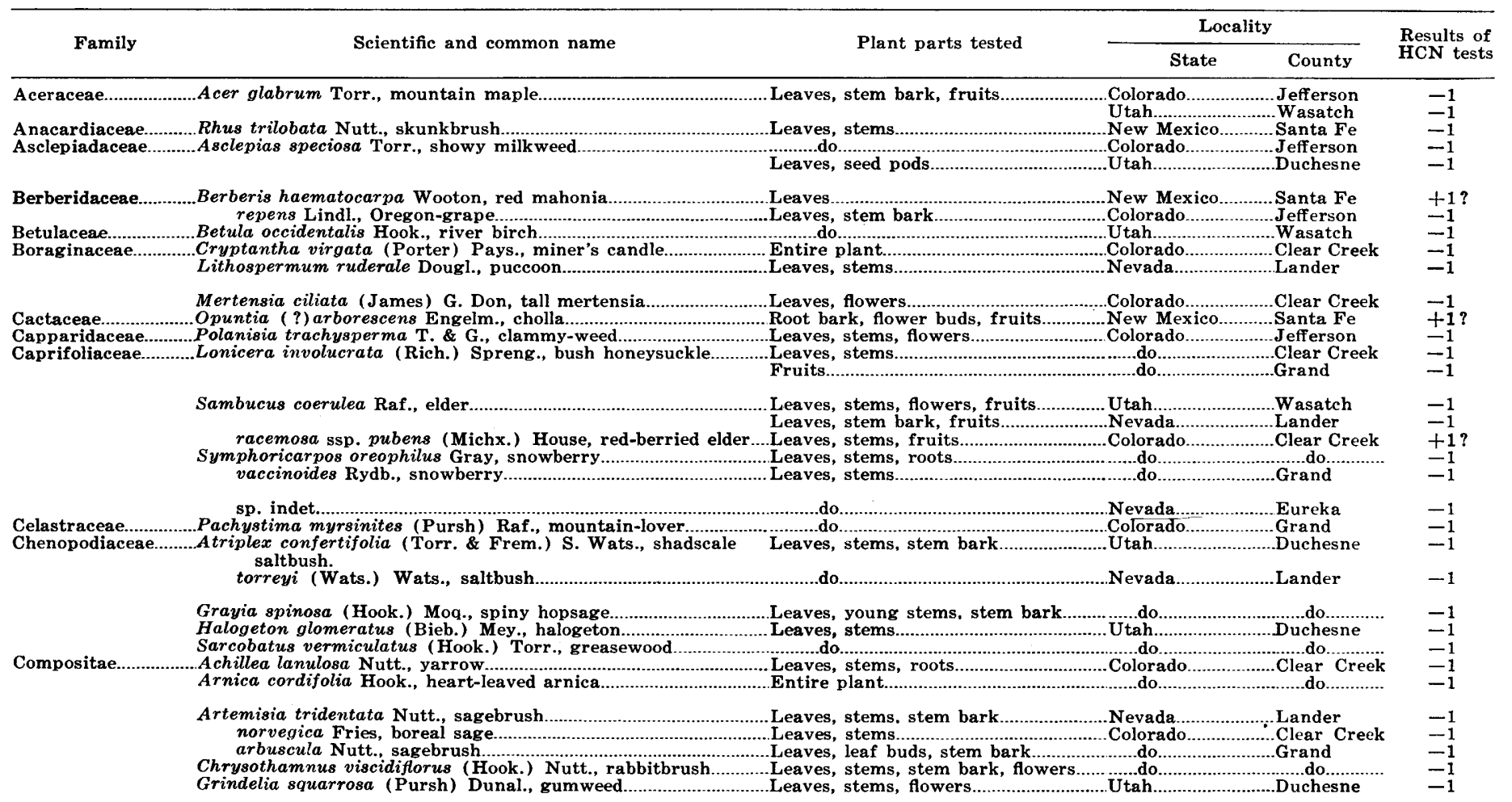


intermedia (Wats.) Heller, bladder-pod.

Eleagnacea

Shepherdia argentea (Pursh) Nutt., buffaloberry Leaves, stems, seed pods Leaves, stem bark, fruit New Mexico........... Santa Fe Nevada...................................... tems

Shepherdia argentea (Pursh) Nutt., buffaloberry........................Leaves, stems, stem bark

Leaves, stems, stem bark ............................................ Lander

Ephedraceae edra torrevana wats., buffaloberry.

Leaves, root bark viridis Coville, Mormon tea

Young stems. old stems.

Colorado tems

New Mexico.......... Santa Fe

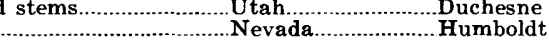

Equisetaceae

Equisetum arvense $\mathrm{L}$.. horsetail

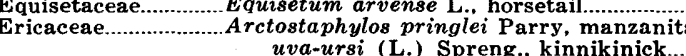

Leaves, stems

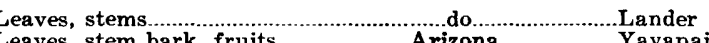

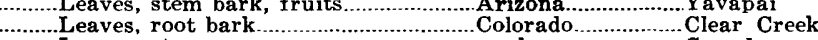

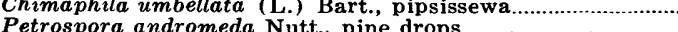
Leaves, stems .................................................................Gran Entire plant

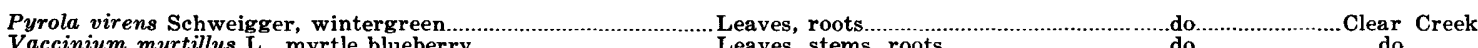

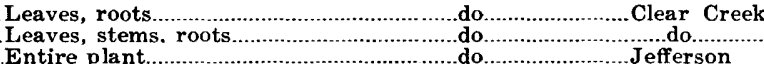

Euphorbiaceae............ Euphorbia dentata Michx

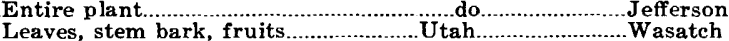
Leaves, stems, stem bark, fruits......... Arizona..................... Yavapai

Gentianaceae. Gentiana calycosa Griseb., gentian Leaves, stems, flowers. Colorado.................. Clear Creek Gentianella amarella (L.) Boern., amarell Leaves, stems,

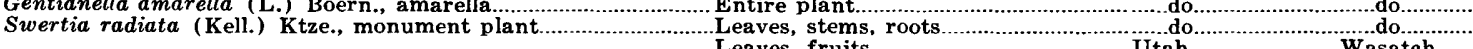

Gramineae Distichlis stricta (Torr.) Rydb., saltgrass

Leaves, fruits

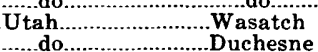

Grossulariaceae.........Ribes americanum Mill., wild gooseberry Leaves, stems Entire plant......................................... Utah montigenum

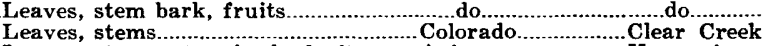

Juglandaceae. Juglans major (Torr.) Heller, Arizon walnut

Leguminosae..............Acacia greggii Gray, catclaw acacia....... Leaves, stems, stem bark, fruits ........Arizona …….......Yavapai 
TABLE 23. - Results of tests for hydrocyanic acid (HCN) in selected species of plants - Continued

\begin{tabular}{|c|c|c|}
\hline \multirow{2}{*}{ Family } & Soiontifie and common name & \multirow{2}{*}{$\begin{array}{l}\text { Results of } \\
\text { HCN tests }\end{array}$} \\
\hline & Scientific and common name & \\
\hline $\begin{array}{l}\text { Leguminosae....... } \\
\text { Liliaceae.............. } \\
\text { Linaceae................ }\end{array}$ & 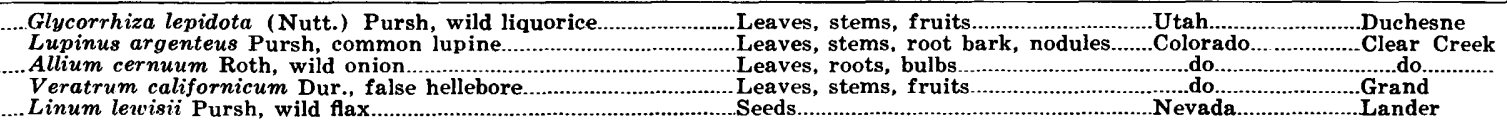 & $\begin{array}{l}-1 \\
-1 \\
-1 \\
-1 \\
+1\end{array}$ \\
\hline $\begin{array}{l}\text { Loasaceae............ } \\
\text { Loranthaceae...... }\end{array}$ & 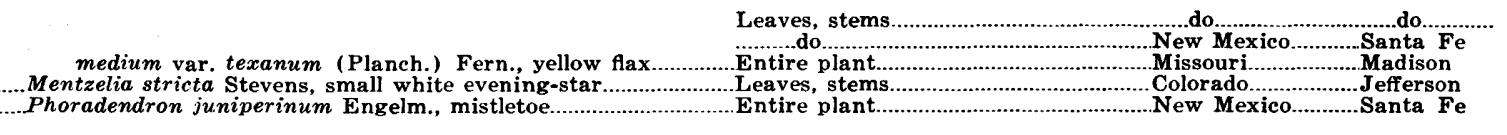 & $\begin{array}{l}+3 \\
+3 \\
-1 \\
-1 \\
+1\end{array}$ \\
\hline $\begin{array}{l}\text { Malvaceae............ } \\
\text { Marchantiaceae. } \\
\text { Moraceae............ } \\
\text { Myricaceae........ } \\
\text { Onagraceae......... }\end{array}$ & 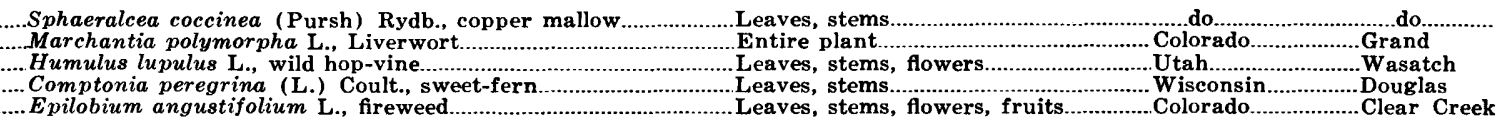 & $\begin{array}{l}-1 \\
-1 \\
-1 \\
-1 \\
-1\end{array}$ \\
\hline $\begin{array}{l}\text { Orchidaceae........ } \\
\text { Papaveraceae..... } \\
\text { Pinaceae.............. }\end{array}$ & 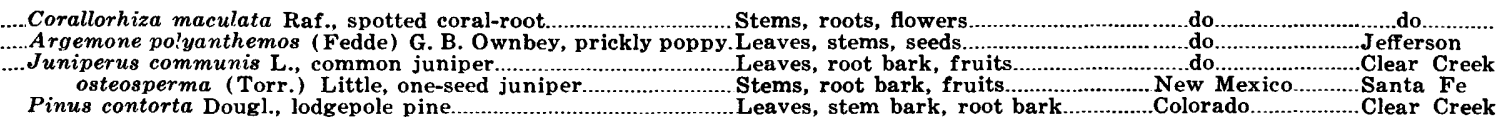 & $\begin{array}{l}-1 \\
-1 \\
-1 \\
+1\end{array}$ \\
\hline $\begin{array}{l}\text { Polemoniaceae... } \\
\text { Polygonaceae...... }\end{array}$ & 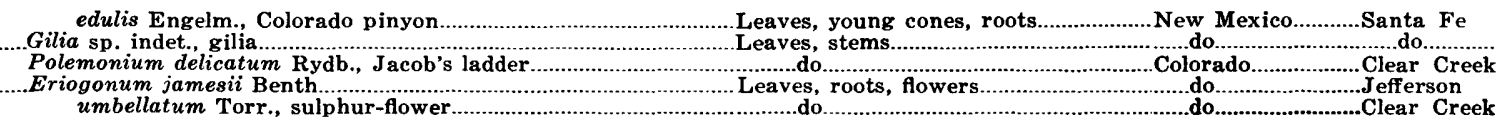 & $\begin{array}{l}-1 \\
-1 \\
-1 \\
-1 \\
-1\end{array}$ \\
\hline Ranunculaceae... & 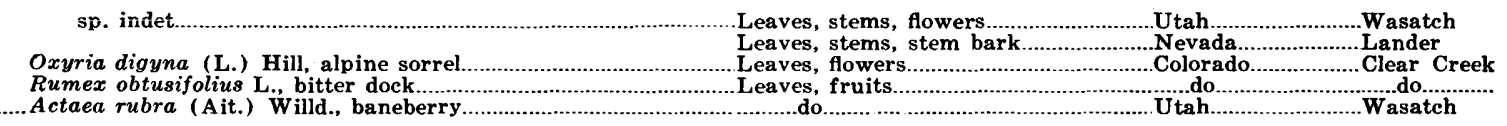 & $\begin{array}{l}-1 \\
=1 \\
=1 \\
-1\end{array}$ \\
\hline & 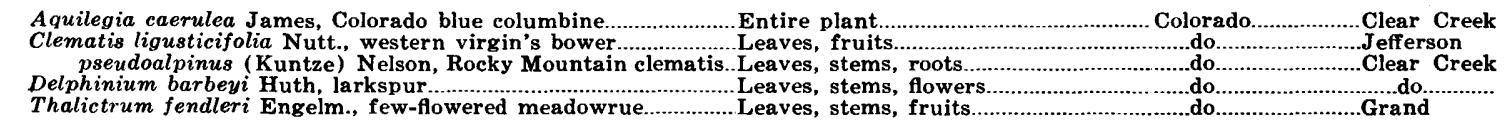 & $\begin{array}{l}+1 \\
+1 \\
+1 \\
-1 \\
-1\end{array}$ \\
\hline $\begin{array}{l}\text { Rhamnaceae......... } \\
\text { Rosaceae.................. }\end{array}$ & $\begin{array}{l}\text { Ceanothus greggii Gray. } \ldots \ldots \ldots \\
\text { Amelanchier pumila Nutt., smooth serviceberry }\end{array}$ & $\begin{array}{l}-1 \\
+1 \\
+4\end{array}$ \\
\hline
\end{tabular}




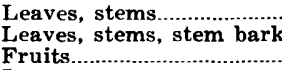

Stem bark

Wiscons

Douglas

Utah.

do...

Wasatch

Leaves, stems, stem bark

.....do.

Lander

Cercocarpus intricatus S. Wats., mountain mahogany

Leaves, stems, stem bark.

....do......................Eureka Utah .................................uab

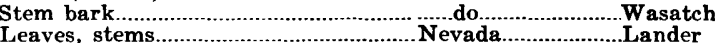

+3
+3
+1
+1
+2

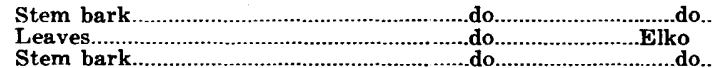

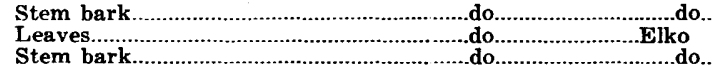

Lander

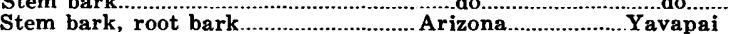

Stems, stem bark.....

Utah.

Duchesne

Leaves, stems, stem bark

Nevada.

Humboldt

montanus Raf., mountain mahogany

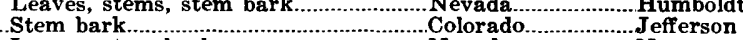

Chamaebatiaria millefolium (Torr.) Maxim., fern bush..............

Leaves, stem bark

Cowania mexicana Don., cliffrose.

Leaves, stems, stem bark

Nevad

Nye

Leaves, stem bark, fruits
L..Leaves, stems, stem bark

Holodiscus dumosus (Nutt.) Heller, ocean spray

microphyllus Rydb., ocean spray

.....do.

Wasatch

Entire plant.

Colorado.

Jefferson

plattensis Nutt., potentilla

Leaves, stem bark

Nevada..

..Lander bark

Crushed seeds

andersonii Gray, desert peach.

Fruit..

do.......................

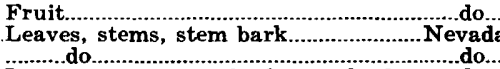

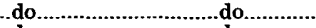

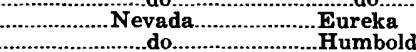

pennsylvanica L.f., bird cherry.

Leaves, stems

.....do...... Lander

persica Sieb. \& Zucc., peach...

Root bark.

Michigan.................Cheboygan

serotina Ehrh., black cherry

(

do. stems...........

Colorado.

Jefterson

virginiana Lh., black cherry.

Leaves,

Dougla

Fruit

Colorado

..Polk

Fruits.

U...do.

Leaves, stem bark

Nevada

Wasatch

Ceaves, stems, stem bark

Utah

Utah.

Leaves, stems, fruits

Leaves, stems, stem bark, fruits..........Utah.

arkansana Porter, wild rose.

Rosa acicularis Lind.
Humboldt

Yavapai

...Wasatch

Wasatch
+1
+1
+3
+1
+2

+1
+1
+2
+2

$-1$

$-1$

-1
-1
+3

+4
+1

+1
+3
+3
+2

+2
+4
+1
+1

+1
+4
+3
+3
+3

-1
-1 
TABLE 23. - Results of tests for hydrocyanic acid (HCN) in selected species of plants - Continued

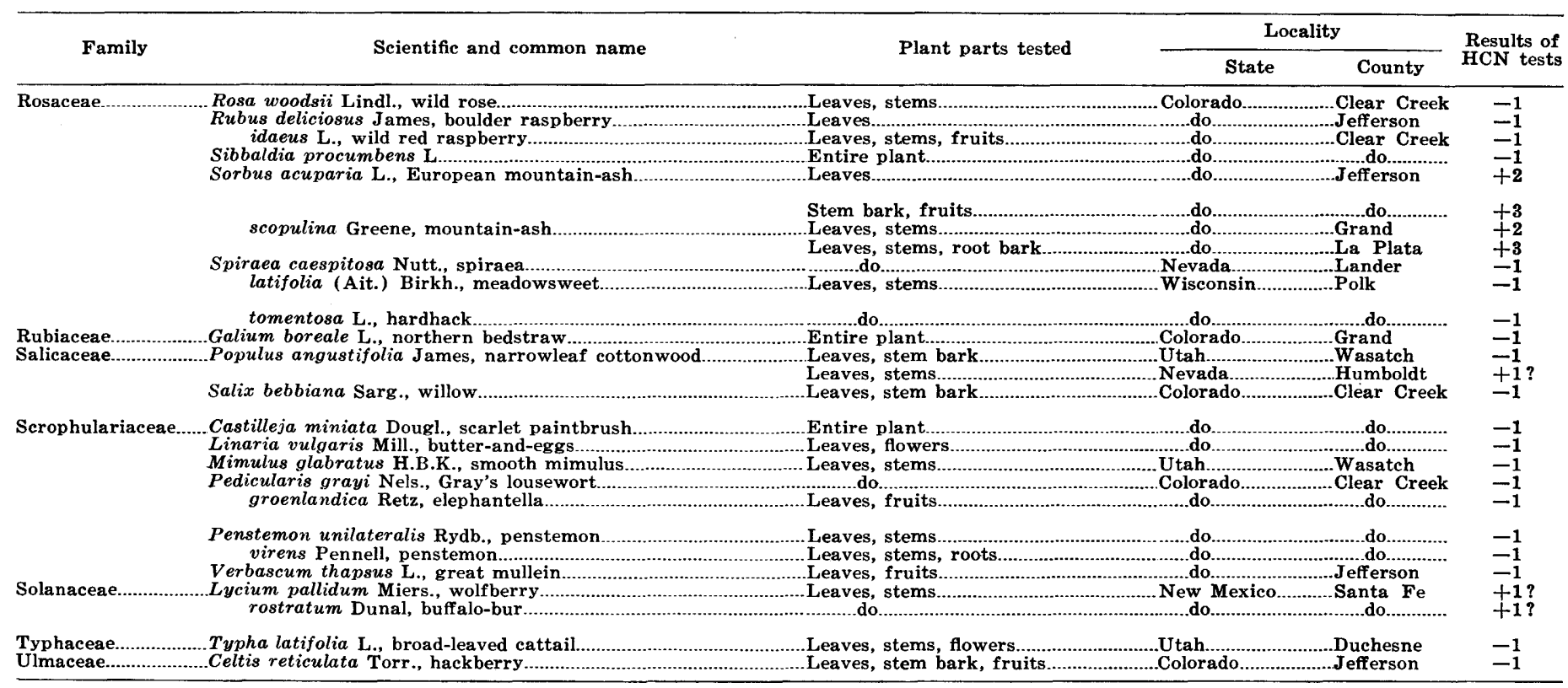


2. Western spruce-fir forest - Mountain-ash, smooth shadbush, and pine drops $(+1$ ?).

3. Alpine meadows and barren - No cyanogenic species found.

4. Sagebrush steppe - Chokecherry, cliffrose, and desert apricot.

5. Saltbrush-greasewood - Mountain mahogany (Cercocarpus montanus and $C$. intricatus), cliffrose, desert apricot, chokecherry, and narrow-leaf cottonwood $(+1$ ?).

6. Juniper-pinyon woodland - Cliffrose, serviceberry, mountain mahogany (Cercocarpus montanus), Utah shadbush, wild flax, desert apricot, red mahonia $(+1$ ?), cholla $(+1$ ?), milkvetch $(+1$ ?), mistletoe $(+1$ ?), one-seeded juniper $(+1$ ?), and bladder pod (Lesquerella fendleri) $(+1$ ?) .

7. Douglas-fir forest - Mountain-ash and red osier dogwood $(+1$ ?).

8. Mountain mahogany-oak scrub - Mountain mahogany (Cercocarpus montanus and C. ledifolius) and serviceberry.

9. Great Basin sagebrush - Mountain mahogany (Cercocarpus montanus and $C$. ledifolius), desert apricot, and Utah shadbush.

10. Grama-tobosa shrub steppe - Utah shadbush and mountain mahogany (Cercocarpus ledifolius).

11. Chaparral - Mountain mahogany (Cercocarpus ledifolius) and chokecherry.

12. Southwestern spruce-fir forest - No cyanogenic species found.

\section{SOLUBILIZATION OF GOLD BY MICROORGANISMS} AND ORGANIC SUBSTANCES

By KenNeth G. DOXTADER ${ }^{1}$

INTRODUCTION

The ability of microorganisms to solubilize elemental gold is discussed in several papers (Parès, 1964a, b, c, 1966; Parès and Cuper, 1964 ; Parès and Giraud, 1964; Parès, Hans-Moevi, and others, 1965; Parès and Martinet, 1964; Parès, Martinet, and others, 1965). These authors presented the results of experiments aimed at studying the gold solubilizing activity of pure cultures of bacteria, either obtained from stock cultures or isolated from gold ore deposits.

The aim of the present study was to test the ability of selected microorganisms to solubilize elemental gold. Bacterial strains of the same type used by Parès and associates were used in this study. In addition, a number of other bacterial isolates, as well as some fungi, were tested. 


\section{GOLD SUBSTRATE}

Powdered gold itself was used as gold substrate in some experiments on the solubilization of gold by organic action, and in other experiments colloidal gold was used. Colloidal gold was prepared for selected gold substrate by dissolving a minus-100-mesh gold powder in boiling aqua regia. The cooled solution was neutralized with $\mathrm{NH}_{4} \mathrm{OH}$ and treated with ascorbic acid to reduce and precipitate the gold. The suspension was centrifuged at 4,000 $\times G$ for 30 minutes, and the gold sediment was washed with $1 \mathrm{~N} \mathrm{H}_{2} \mathrm{SO}_{4}$, re-centrifuged, washed with distilled water, centrifuged again, and resuspended in distilled water. In one series of experiments the aqua regia solution of gold was neutralized with $\mathrm{NH}_{4} \mathrm{OH}$ but was not treated with ascorbic acid. The gold probably was incompletely reduced in this experiment.

\section{CULTURE MEDiA}

The basic mineral salts solution used for the media contained (in grams per liter of distilled water): $\mathrm{NH}_{4} \mathrm{Cl}, 2.0 ; \mathrm{Na}_{2} \mathrm{HPO}_{4}$, $6.0 ; \mathrm{KH}_{2} \mathrm{PO}_{4}, 3.0 ; \mathrm{NaCl}, 3.0 ; \mathrm{MgCl}_{2}, 0.04 ; \mathrm{Na}_{2} \mathrm{SO}_{4}, 0.161$. The final $\mathrm{pH}$ of the solution was 7.0 to 7.1. Glucose was utilized as a carbon-energy source at a concentration of $10 \mathrm{~g} / \mathrm{l}$. Where indicated, yeast extract (Difco) was included in the medium at the rate of $0.5 \mathrm{~g} / \mathrm{l}$, or peptone (Difco) was included at $2.5 \mathrm{~g} / \mathrm{l}$.

\section{CULTURE PROCEDURES}

The general experimental approach was to incubate $150-\mathrm{mg}$ quantities of gold with $50-\mathrm{ml}$ aliquots of culture medium contained in 250-ml Erlenmeyer flasks. The media were sterilized by autoclaving for 20 minutes at $15 \mathrm{lbs} / \mathrm{in}^{2}{ }^{2}$ steam pressure and a temperature of $120^{\circ} \mathrm{C}$. The sterilized media were added aseptically to flasks containing gold sterilized by exposure to acetone which was then evaporated.

The flasks of media were inoculated from stock cultures. The cultures were incubated at room temperature $\left(27^{\circ}-29^{\circ} \mathrm{C}\right)$.

\section{ANALYSIS OF THE CULTURE LIQUIDS FOR SOLUBLE GOLD}

The culture liquids were centrifuged for 30 minutes at 4,000 $\times G$. The supernatant fluid was evaporated to dryness, and the dry residue was treated with bromine water and 48-percent $\mathrm{HBr}$. The gold in the resulting solution was extracted with methyl isobutyl ketone. The organic extract was analyzed on a PerkinElmer Model 303 Atomic Absorption Spectrophotometer by using the following instrument settings: Wavelength, 2,428 angstroms; slit, 5 ( $3 \mathrm{~mm}, 20 \mathrm{~A})$; lamp, Perkin-Elmer gold hollow cathode, 14 milliampere current; fuel, acetylene (flow, 7.5); oxidizer, air (flow, 9.0). 


\section{RESULTS AND DISCUSSION}

\section{SOLUBILIZATION OF GOLD BY STOCK CULTURES OF BACTERIA AND FUNGI}

Initial studies were aimed at determining the effect on gold solubilization of the following variables: (1) Microbial species, (2) culture medium, (3) incubation conditions (shaking), (4) incubation time, and (5) physical form of the gold.

Ten bacterial strains obtained from the culture collection of the Colorado State University Department of Microbiology were inoculated into flasks of culture medium containing powdered gold. Three media were utilized: glucose, glucose-plus-yeast extract, and glucose plus peptone.

The cultures were incubated in a stationary fashion for 8 weeks, and at weekly intervals, soluble gold was measured. None of the cultures showed significant gold solubilization during the incubation period. At no time did the level of gold in solution exceed $0.5 \mathrm{ppm}$.

Since the small surface area of the powdered gold might be a limiting factor in the microbial solubilization process, colloidal gold was prepared and incubated with the test organisms. For all cultures grown in the glucose medium, the level of gold in solution was extremely low $(<0.5 \mathrm{ppm})$ throughout the incubation period. Small but significant levels of soluble gold were detected in the cultures grown in glucose-plus-yeast extract medium and in glucose plus peptone (table 24). The amounts of gold solubilized were erratic. The values reported in table 24 are the highest soluble gold concentrations found throughout the 8-week sampling period.

TABLE 24. - Solubilization of colloidal gold by bacterial strains grown in glucose medium with yeast extract and with peptone

[Each culture was grown for 8 weeks : gold was analyzed at weekly intervals; highest detected levels are reported]

\begin{tabular}{|c|c|c|}
\hline \multirow{2}{*}{ Strain } & \multicolumn{2}{|c|}{ Highest level of gold in solution (ppm) } \\
\hline & With yeast extract & With peptone \\
\hline Agrobacterium tumefaciens 1 ..... & 0.51 & 0.91 \\
\hline 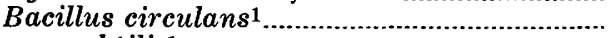 & .83 & .98 \\
\hline subtilis ${ }^{1} \ldots \ldots \ldots \ldots \ldots$ & .22 & 1.19 \\
\hline megaterium 1 ........... & .71 & 1.08 \\
\hline Proteus vulgaris ${ }^{1}$... & .53 & 1.21 \\
\hline 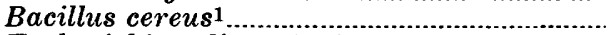 & .59 & 1.70 \\
\hline Escherichia coli strain $\mathbf{G}^{1}$.. & .49 & .90 \\
\hline 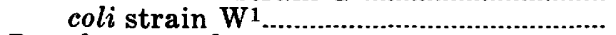 & .99 & 1.20 \\
\hline Pseudomonas fluorescens 1 ................................ & .83 & 1.18 \\
\hline Sterile medium & .62 & 1.13 \\
\hline Sterile distilled water & .00 & .00 \\
\hline
\end{tabular}

1Shown by Parès and coworkers (Parès, 1964a, b, c, 1966 ; Parès and Cuper, 1964; Parès and Giraud, 1964 ; Parès, Hans-Moevi, and others, 1965: Parès and Martinet, 1964; Pares, Martinet, and others, 1965) to be capable of solubilizing gold. 
On the basis of the low levels of gold detected and the sensitivity of the chemical assay, it is difficult to draw definite conclusions regarding the relative levels of metal solubilization of different cultures, but, apparently, some solubilization took place in both cultures and in sterile media. By comparison with the gold levels in the uninoculated media, little, if any, additional gold was solubilized by the test strains. In fact, there is a slight indication that some of the cultures removed gold from solution.

The significant levels of gold in solution in the uninoculated culture medium suggest that organic solutions, such as peptone and yeast extract, may in themselves be capable of solubilizing gold. The glucose-peptone medium is similar in composition to one used by Parès and her coworkers. Although they showed that this medium was capable of supporting microbial gold solubilizing activity, they made no mention of the direct effect of the medium on gold.

Three fungal strains from the stock culture collection were inoculated into glucose-peptone medium containing colloidal gold. The cultures were incubated (without shaking) for 6 weeks; gold analyses were performed each week. As shown in table 25, small but significant amounts of gold were detected in the culture broths and in the uninoculated medium.

In an effort to enhance the process of gold solubilization by microorganisms, selected bacteria were grown in flasks of glucosepeptone medium which were placed on a shaker. In most of the flasks, no significant difference was noted in the levels of gold in solution (table 26). Cultures were grown in glucose-peptone medium containing colloidal gold for 8 weeks; the levels of gold reported are the highest found in weekly analysis of the cultures.

SOLUBILIZATION OF GOLD BY MICROBIAL ISOLATES FROM SOIL AND SEDIMENTS

Efforts were made to isolate microorganisms capable of solubilizing greater quantities of gold than those found with the stock culture collection strains. Standard procedures of isolation were

TABLE 25. - Gold solubilization by fungal strains grown in glucose-peptone medium

\begin{tabular}{|c|c|c|c|c|}
\hline \multirow{2}{*}{ Strain } & \multicolumn{4}{|c|}{ Incubation period (weeks) } \\
\hline & 1 & 2 & 3 & 6 \\
\hline & \multicolumn{4}{|c|}{ Gold in solution (ppm) } \\
\hline Aspergillus flavus.. & 0.91 & 0.82 & 1.11 & 1.05 \\
\hline 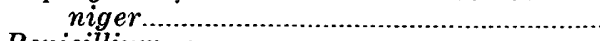 & .88 & .81 & .95 & 1.01 \\
\hline Penicillium sp........................................... & .91 & .91 & .95 & .99 \\
\hline Sterile medium & .81 & .93 & .95 & 1.02 \\
\hline
\end{tabular}


TABLE 26. - Effect of shaking flasks on microbial solubilization of gold

\begin{tabular}{|c|c|c|}
\hline \multirow{2}{*}{ Strain } & \multicolumn{2}{|c|}{ Gold in solution (ppm) } \\
\hline & With shaking & Without shaking \\
\hline Escherichia coli strain G.. & .........0.90 & 0.99 \\
\hline 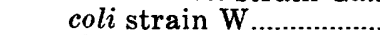 & ........... & 1.29 \\
\hline Pseudomonas fluorescens ${ }^{1}$ &. .1 .20 & 1.22 \\
\hline Bacillus cereus $1 . . . . . . . . . . . . . . . .$. &. .1 .62 & 1.42 \\
\hline Proteus vulgaris ${ }^{1}$... & $\ldots .40$ & 1.44 \\
\hline Sterile medium ........... & .........1.10 & 1.09 \\
\hline Sterile water............. & …..... 00 & .00 \\
\hline
\end{tabular}

'Shown by Parès and coworkers (Parès, 1964a, b, c, 1966; Parès and Cuper, 1964; Parès and Giraud, 1964 ; Parès, Hans-Moevi, and others, 1965 ; Parès and Martinet, 1964 ; Parès, Martinet, and others, 1965) to be capable of solubilizing gold.

utilized to obtain bacterial strains from gold-containing sediments collected near Cripple Creek, Colo., and soil collected near Empire, Colo. The samples of soil and sediment were suspended in sterile water and aliquots spread on the surface of glucose-peptone medium solidified with agar. Five major bacterial types were isolated from each type of sample and inoculated into glucose-peptone medium containing colloidal gold. As shown in table 27, the levels of gold solubilized were comparable to those found with the strains from the stock culture collection used in the previous experiments.

TABLE 27. - Gold solubilization by bacterial strains isolated from soil and sediment 1

\begin{tabular}{|c|c|c|c|}
\hline Strain & $\begin{array}{c}\text { Highest level of gold } \\
\text { in solution (ppm) }\end{array}$ & Strain & $\begin{array}{l}\text { Highest level of gold } \\
\text { in solution (ppm) }\end{array}$ \\
\hline $\begin{array}{l}\text { C-1. } \\
\text { C-2. } \\
\text { C-3. } \\
\text { C-4. } \\
\text { C-5. } \\
\text { E-1. }\end{array}$ & 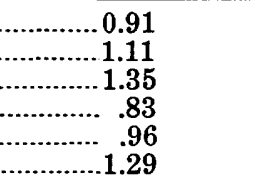 & $\begin{array}{l}\text { E-2. } \\
\text { E-2. } \\
\text { E-3. } \\
\text { E-4. } \\
\text { E-5. } \\
\text { Ster }\end{array}$ & 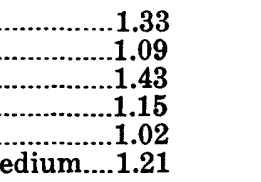 \\
\hline
\end{tabular}

${ }^{1} \mathrm{C}$ strains were isolated from Cripple Creek sediment; $\mathrm{E}$ strains from Empire soil. Cultures were grown in glucose-peptone medium for 8 weeks; gold analyses were made at weekly intervals.

\section{SOLUBILIZATION OF VARIANTLY PREPARED COLLOIDAL GOLD}

In the preparation of colloidal gold from metal powder, on one occasion the ascorbic acid reducing agent was inadvertently omitted from the procedure. The resulting gold precipitate, which likely contained a slightly soluble gold compound, was extensively washed with $1.0 \mathrm{~N} \mathrm{H}_{2} \mathrm{SO}_{4}$ and water and then supplied to cultures in the usual way. Gold in the nutrient solution at the end of 4 days (table 28) may be due to the presence of soluble gold in the culture medium. The increase in dissolved gold in the subsequent 4-day period, however, must be considered as solution of gold by the microbial strains. 
TABLE 28. - Effect of microbial strains on variantly prepared colloidal gold

[50-ml quantities of glucose-peptone medium or water were incubated with $0.015 \mathrm{~g}$ of gold]

\begin{tabular}{|c|c|c|}
\hline \multirow{2}{*}{ Strain } & \multicolumn{2}{|c|}{ Gold in solution (ppm) } \\
\hline & After 4 days & After 8 days \\
\hline Agrobacterium tumefaciens... & 11.0 & 12.7 \\
\hline 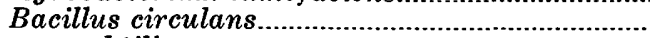 & 16.3 & 21.3 \\
\hline subtilis............................... & 17.7 & 26.9 \\
\hline megaterium.............................. & 17.1 & 22.5 \\
\hline Proteus vulgaris... & 9.5 & 18.4 \\
\hline 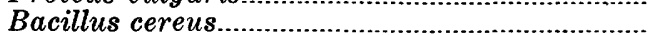 & 22.5 & 25.9 \\
\hline Escherichia coli strain G.......... & 21.2 & 23.6 \\
\hline coli strain W & 13.4 & 22.4 \\
\hline Pseudomonas fuorescens. & 8.3 & 12.1 \\
\hline Sterile medium & 17.5 & 24.1 \\
\hline Distilled water. & .00 & .00 \\
\hline
\end{tabular}

THE ACTION OF PEPTONE SOLUTIONS ON COLLOIDAL GOLD

A study was made of the ability of the glucose-peptone medium to solubilize gold under sterile conditions. Colloidal gold was incubated with the complete medium and with separate organic and inorganic components of the medium. As shown in table 29, greatest solubilization occurred in the complete medium. These results would suggest that peptone acts together with certain minerals in the culture medium to bring about gold solubilization.

TABLE 29. - Solubilization of gold by components of glucose-peptone medium

[Medium components were shaken with colloidal gold $(0.015 \mathrm{~g} / 50 \mathrm{ml})$ ]

\begin{tabular}{|c|c|c|c|c|}
\hline \multirow{2}{*}{ Medium component } & \multicolumn{4}{|c|}{ Gold in solution (ppm) } \\
\hline & 1 hour & 5 hours & 24 hours & 48 hours \\
\hline 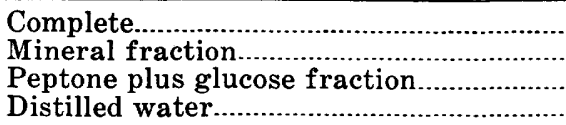 & $\begin{array}{r}0.46 \\
.28 \\
.02 \\
.00\end{array}$ & $\begin{array}{r}1.13 \\
.49 \\
.05 \\
.00\end{array}$ & $\begin{array}{r}2.47 \\
.97 \\
.48 \\
.00\end{array}$ & $\begin{array}{r}2.52 \\
1.18 \\
.86 \\
.00\end{array}$ \\
\hline
\end{tabular}

\section{ISOLATION OF SOIL MICROORGANISMS RESISTANT TO HIGH CONCENTRATIONS OF METALLIC IONS}

A review of the literature indicates that a high proportion of the microorganisms in soil are potentially capable of solubilizing minerals, the activity not being restricted to any single microbial group. Microorganisms which are able to degrade minerals containing heavy metals and noble metals would appear to be adversely affected by the toxic action of the metal ions which they liberate. Such toxicities might effectively limit the ability of microorganisms to attack and solubilize minerals. A study was made of the ability of isolated microorganisms to tolerate high concentrations of metallic ions.

One-gram quantities of Cass silt loam were inoculated into glucose-mineral-salts medium containing a high concentration of 
a metallic salt. Where possible, the sulfate or chloride salt of the metals was used. A total of 16 metallic elements at various concentrations was studied.

Aliquots of the culture liquids were transferred to fresh medium of identical composition after 5 days' incubation.

This procedure was repeated once more prior to plating out some of the liquid of the final culture on glucose-salts medium containing agar and an appropriate level of metallic ion. Organisms that developed at the highest metal concentrutions were isolated and then inoculated into liquid-culture medium in order to establish with certainty that they were capable of growth in the presence of the metals. Isolated bacteria and fungi were capable of growth in liquid media containing the following metallic ions at the indicated concentrations :

[SS, saturated solution]

\begin{tabular}{|c|c|}
\hline $\begin{array}{l}\text { Maximum concentration } \\
\text { at which growth } \\
\text { occurred (ppm) }\end{array}$ & $\begin{array}{l}\text { Maximum concentration } \\
\text { at which growth } \\
\text { occurred (ppm) }\end{array}$ \\
\hline 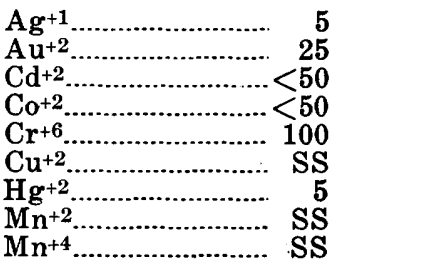 & 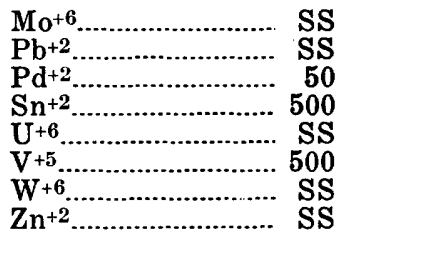 \\
\hline
\end{tabular}

These results suggest some upper concentration limits for the growth of soil microorganisms in the glucose-mineral-salts medium containing metallic ions. It should be pointed out, however, that in other media or by the use of other isolation techniques these limits might be quite different.

\section{STUDIES OF THE DISTRIBUTION OF GOLD IN SOILS AND VEGETATION PREPARATION OF SAMPLES}

All soils were sieved through a $2-\mathrm{mm}$ screen and the coarse material rejected, except in special studies of the variation of gold content with soil particle size.

All rocks were ground to pass a $0.2-\mathrm{mm}$ screen.

Samples of mull were sieved through a $2-\mathrm{mm}$ screen and the coarse material rejected. Some mull samples for special studies were separated by flotation in demineralized water into principally organic (floats) and inorganic (sinks) fractions.

Samples of vegetation suspected of surface contamination were washed with demineralized water before being ashed.

Samples of wood consisted of major limbs or trunks of trees 
that were shaved clean of bark; conversely, samples of "bark" contained a large percentage of wood.

\section{IGNITION AND ASHING}

Samples of rock, soil, and mull were ignited in porcelain dishes over Fisher burners to oxidize sulfides and organic matter. Occasional stirring with a glass rod facilitated the oxidation. Samples of vegetation were ashed in furnaces with temperature controls that permitted a slow increase in temperature to a maximum of $450^{\circ} \mathrm{C}$. The heating and cooling cycle was 24 hours.

\section{SOLUTION AND ESTIMATION OF GOLD}

The method of analysis used for gold followed that described by Thompson, Nakagawa, and VanSickle (1968). For rocks and soils the procedure was to transfer $10 \mathrm{~g}$ of the sample to a $25-$ by $200-\mathrm{mm}$ screw-capped culture tube, add $20 \mathrm{ml}$ concentrated $\mathrm{HBr}$ containing 0.5 percent $\mathrm{Br}_{2}$, cap the tube, and shake for 20 minutes. Add $20 \mathrm{ml}$ of water, $10 \mathrm{ml}$ of methyl isobutyl ketone, and shake for 2 minutes. Centrifuge to separate the liquid phases, and transfer the ketone with an automatic pipet to a similar tube containing $25 \mathrm{ml}$ of $0.1 \mathrm{~N}$ hydrobromic acid and shake for about 30 seconds to remove excess ferric bromide from the ketone. Atomize the ketone in an atomic absorption spectrophotometer. Compare with standard solutions atomized under the same conditions. For limestones and the ash of organic materials, the procedure was to transfer $10 \mathrm{~g}$ of the sample to a $150-\mathrm{ml}$ beaker, moisten with water, and add the $\mathrm{HBr}-\mathrm{Br}_{\text {: }}$ solution slowly until frothing ceases. Then add $20 \mathrm{ml}$ of the $\mathrm{HBr}-\mathrm{Br}_{2}$ solution and boil until only 10-15 ml remains in the beaker. Add a drop of $\mathrm{Br}_{2}$, transfer the contents of the beaker to a 20 - by $200-\mathrm{mm}$ culture tube, and proceed as above.

\section{PRECISION OF DATA}

The first consideration in a chemical analysis is the use of a sample that truly represents the material under test. If we grant that the collected sample is representative, we must be able to take an equally representative subsample for analysis. Obviously, the precision of the analysis of a given sample is limited by the precision of subsampling. The sampling and subsampling of oxidized earth materials for their gold content is complicated by the erratic occurrence of particulate gold within the material being sampled.

The shape of particulate gold varies from plates, to wires, to knobby spheres, but for simplicity in calculating the effect of size and weight of gold particles on the precision of analysis, let us consider cubes of gold. A single $0.1-\mathrm{mm}$ cube of gold weighs $19 \mu \mathrm{g}$ - in a $10-\mathrm{g}$ subsample this single particle would give $1.9 \mathrm{ppm}$ 
gold. A $0.01-\mathrm{mm}$ cube of gold weighs $0.019 \mu \mathrm{g}$; in a $10-\mathrm{g}$ subsample, 21 of these particles would give $0.04 \mathrm{ppm}$ gold, which is the lower limit of estimation reported in this paper. A micrometer $(0.001$ $\mathrm{mm}$ ) cube of gold weighs 19 picograms $\left(10^{-12} \mathrm{~g}\right)$; in a $10-\mathrm{g}$ sample, 21,000 of these particles would give $0.04 \mathrm{ppm}$ gold.

Tourtelot (1968, p. F8) published a diagram (fig. 3, this report) that shows the grain size of gold versus the number of particles of gold in samples of the indicated sizes for 1-, 10-, and 100-g samples containing $1 \mathrm{ppm}$ gold, and for a 1-g sample containing $0.1 \mathrm{ppm}$ gold. From this diagram it is evident that a $10 \mathrm{~g}$ sample containing 1 particle of gold $0.1 \mathrm{~mm}$ in diameter would contain $1 \mathrm{ppm}$ gold, whereas more than 1,000 particles of $0.0068 \mathrm{~mm}$ would be present at the $1 \mathrm{ppm}$ range.

Fortunately, almost all the material reported in this paper contained relatively fine grained gold. The small relative standard deviation shown in table 30 could not have been obtained on materials containing gold in excess of $0.01 \mathrm{~mm}$ in diameter. The values of 0.07 to $0.09 \mathrm{ppm}$ for the ash of wood (sample No. CC-552) suggest that the gold was present as particles of less than $0.01 \mathrm{~mm}$ in diameter.

Clifton, Hunter, Swanson, and Phillips (1969) studied the problem of sample size and meaningful gold analysis. They set as a goal (p. C2) "that it be 95 percent probable that the true gold

TABLE 30. - Precision of replicate analyses for gold in various materials

\begin{tabular}{|c|c|c|c|c|c|c|}
\hline \multirow[b]{2}{*}{ Sample No. } & \multirow{2}{*}{$\begin{array}{c}\text { Number of } \\
\text { determi- } \\
\text { nations }\end{array}$} & \multicolumn{4}{|c|}{ Gold (ppm) } & \multirow{2}{*}{$\begin{array}{l}\text { Relative } \\
\text { standard } \\
\text { deviation } \\
\text { (percent) }\end{array}$} \\
\hline & & $\begin{array}{c}\text { Highest } \\
\text { value }\end{array}$ & $\begin{array}{c}\text { Lowest } \\
\text { value }\end{array}$ & $\begin{array}{l}\text { Mean } \\
\text { value }\end{array}$ & $\begin{array}{l}\text { Standard } \\
\text { deviation }\end{array}$ & \\
\hline \multicolumn{7}{|c|}{ Soil profile from Empire, Colo. } \\
\hline $\begin{array}{l}534-\mathrm{BH}-4 \\
534-3 \ldots \ldots \ldots \ldots \\
\mathbf{5 3 4}-5 \\
534-7 \ldots \ldots \ldots \ldots \ldots \\
534-8 \\
534-9\end{array}$ & $\begin{array}{l}6 \\
6 \\
5 \\
6 \\
6 \\
6\end{array}$ & $\begin{array}{r}0.76 \\
.20 \\
.06 \\
.20 \\
36.3 \\
22.0\end{array}$ & $\begin{array}{c}0.24 \\
.08 \\
.04 \\
.08 \\
13.8 \\
17.9\end{array}$ & $\begin{array}{r}0.43 \\
.12 \\
.05 \\
.13 \\
20.8 \\
19.6\end{array}$ & $\begin{array}{l}0.22 \\
.05 \\
.01 \\
.05 \\
8.1 \\
1.4\end{array}$ & $\begin{array}{r}51 \\
42 \\
20 \\
38 \\
39 \\
7\end{array}$ \\
\hline \multicolumn{7}{|c|}{ Ash of humus under Douglas-fir, Empire, Colo. } \\
\hline EM-772-H. & 6 & 0.31 & 0.15 & 0.24 & 0.06 & 25 \\
\hline \multicolumn{7}{|c|}{ Ash of humus under lodgepole pine, Empire, Colo. } \\
\hline EM-698-H-16...... & 7 & 0.55 & 0.15 & 0.29 & 0.13 & 45 \\
\hline \multicolumn{7}{|c|}{ Ash of wood of limber pine, Cripple Creek, Colo. } \\
\hline CC-552 ....................... & 5 & 0.09 & 0.07 & 0.086 & 0.009 & 10 \\
\hline \multicolumn{7}{|c|}{ Ash of bark of limber pine, Cripple Creek, Colo. } \\
\hline $\mathrm{CC}-552 \ldots$ & 7 & 0.30 & 0.15 & 0.216 & 0.06 & 27.7 \\
\hline \multicolumn{7}{|c|}{ Ash of bark of lodgepole pine, Empire, Colo. } \\
\hline EM-868-V-2 ......... & 5 & 0.27 & 0.11 & 0.142 & 0.072 & 50 \\
\hline
\end{tabular}




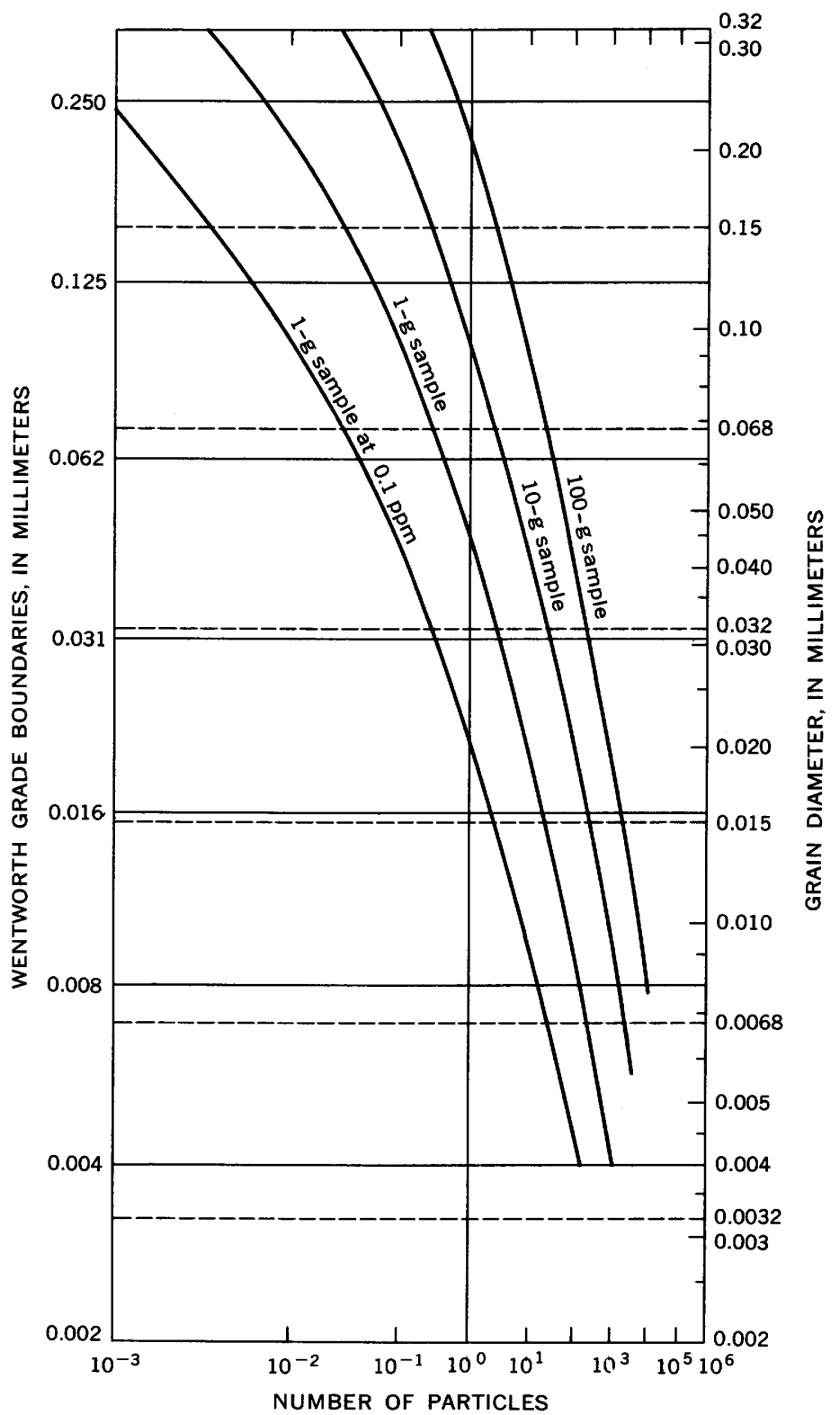

Figure 3. - Number of particles of gold at $1 \mathrm{ppm}$ in samples having different weights, and for a $1-\mathrm{g}$ sample at $0.1 \mathrm{ppm}$. From Tourtelot (1968, p. F8).

content of the deposit be no more than approximately 50 percent larger or smaller than the gold content obtained by chemical analysis of a sample." They further stated (p. C2) that "the number 
of gold particles in the sample is the only factor controlling the precision of the chemical analysis if, in addition to assuming that the gold particles are distributed randomly, it is also assumed that (1) gold particle mass is uniform, (2) gold particles make up less than 0.1 percent of all the particles, (3) the sample contains at least 1,000 particles of all kinds, and (4) analytical errors are absent." They concluded (p. C2) that "a sample has the minimum adequate size then if it is large enough that it can be expected to contain 20 particles of gold." This idealized model of random distribution of gold particles of uniform mass and no analytical error then requires a minimum of 20 gold particles for a \pm 50 -percent error.

The difficulty encountered in soils containing coarse gold is illustrated by the results of the determination of gold in eighteen 10-g subsamples of a single soil sample:

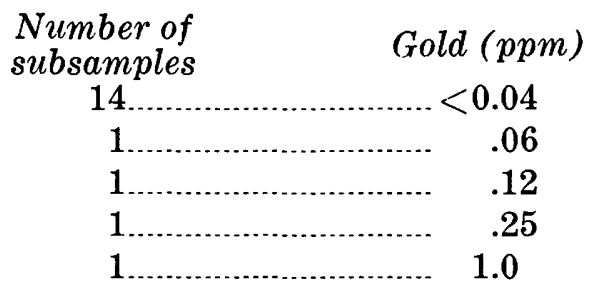

This soil, from the Copper Basin district in Arizona, contained wire gold that was observed by panning. One cannot calculate a standard deviation for these data, and it seems obvious that in this example a representative $10 \mathrm{-g}$ subsample could not be taken.

In conclusion, the precision of the gold determinations given in this paper is usually represented by a relative standard deviation of less than \pm 50 percent. This error is a combination of subsampling and analytical error. The low relative standard deviation obtained in some samples suggests that gold is present as extremely fine particles in the samples, thus permitting a measure of the precision of the analytical method.

\section{STUDIES OF GOLD IN SOIL PROFILES AND VEGETATION}

Soil profiles and vegetation were sampled in 12 gold districts in Colorado, Utah, Nevada, and Arizona, and both the soil and vegetation were analyzed for gold content. Figures 4-6 show the gold content of the soil profiles including the gold humus layer and of vegetation at the sample sites and also give a description of the environment in which the soils were collected. The soil profiles sampled for this study are generally weakly developed because they are in areas where frost action or soil creep coupled with climate inhibit soil development. 
The soils with prefixes EM, CC, GH, B, and LP (figs. $4 A-F$; $5 A-C, E-I ; 6 E)$ were collected at relatively high altitudes in the Rocky Mountains of Colorado. These soils are characterized by a 1- to 3-inch-thick mull (forest humus) layer described on page 65 . The mineral soil is composed of a gray to gray-brown ash-textured A horizon 2-4 inches thick that is underlain by a yellow to yellowbrown colluvial layer of silt, sand, pebbles, and cobbles that does not change noticeably in texture and composition downward to bedrock.

The soils with prefixes $\mathrm{U}, \mathrm{M}, \mathrm{CA}$, and GA (figs. $4 I, 5 D, 6 A-D$ ) were sampled in arid localities in Utah and Nevada. These soils are composed of a weakly developed gray to light-brown loam A horizon that overlies a light-gray to yellow-gray colluvium which is limy and more or less cemented.

The soils with the prefix NB (figs. $5 J, 6 C$ ) were collected in an arid locality in central Nevada. These soils are moderately thick, however, because they formed from hydrothermally altered basalt in an area of gently rolling topography. They are characterized by a dark-brown sand loam A horizon 2-3 inches thick underlain by a red-brown clay loam B horizon $9-18$ inches thick that has a blocky structure. The B horizon is underlain by a limy colluvial layer of silt, sand, pebbles, and cobbles.

The soils sampled in the Copper basin area of west-central Arizona (prefix CB, fig. 4G, $H$ ) formed from quartz monzonite grus. This soil is composed of a yellow to gray-brown sand loam A horizon 3-4 inches thick that overlies a yellow sand loam B horizon $7-16$ inches thick. The grus below the $A$ and $B$ horizons does not show any noticeable soil development.

The high concentration of gold in humus and in soil layers near the top of several of the soil profiles (figs. 4, 5) is due primarily to biogeochemical cycling of gold as described by Goldschmidt (1937, p. 670).

The biogeochemical cycle is the prime factor in the concentration of gold in the upper layers of the soil profiles sampled during this study. Removal of soil particles by surface runoff and by wind erosion are secondary factors in the concentration of gold in the upper part of the soil profiles. Kinkel and Lesure (1968, p. D174) concluded that gold in the upper layers of soil profiles collected in the DeKalb prospect area, Kershaw County, S.C., was concentrated in these layers by removal of soil material during surface runoff.

The high concentration of gold near the bottom of the profiles (figs. 4, 6) may be due to the release of gold from disintegrating fragments of vein material or to the downward migration of gold 
particles within the soil profiles during downslope creep of the soil, or both. An example of the former is soil profile EM-218-C (table 31 ) in which pebbles containing as much as $11 \mathrm{ppm}$ gold at a depth range of 12-18 inches apparently did not contribute gold to the soil fraction, whereas pebbles containing 1.0 and $3.8 \mathrm{ppm}$ gold at a depth range of 79-94 inches apparently did

TABLE 31. - Comparison of gold content between soil (2.0-mm diameter and smaller) and cobbles and pebbles (>2.0-mm diameter) in soil profile EM-218-C (fig. 7A), Empire district, Clear Creek County, Colo.

\begin{tabular}{|c|c|c|c|c|c|}
\hline \multirow{2}{*}{$\begin{array}{l}\text { Depth } \\
\text { (in.) }\end{array}$} & \multicolumn{2}{|c|}{ Gold content (ppm) } & \multirow{2}{*}{$\begin{array}{l}\text { Depth } \\
\text { (in.) }\end{array}$} & \multicolumn{2}{|c|}{ Gold content (ppm) } \\
\hline & Soil & $\begin{array}{l}\text { Pcbbles and } \\
\text { cobbles }\end{array}$ & & Soil & $\begin{array}{l}\text { Pcbbles and } \\
\text { cobbles }\end{array}$ \\
\hline $0-3$ & 0.19 & $<0.04$ & $42-55$ & $<0.04$ & $<0.04$ \\
\hline & .08 & $<.04$ & $55-67$ & $<.04$ & $<.04$ \\
\hline $4.5-8$ & .67 & $<.04$ & -79 & $<.04$ & $<.04$ \\
\hline $8-12$ & .10 & $<.04$ & -89 & .18 & 1.0 \\
\hline $12-18$ & .12 & 11.0 & -94 & 1.5 & 3.8 \\
\hline $18-29$ & $<.04$ & $<.04$ & -102 & .46 & .08 \\
\hline $29-42$ & $<.04$ & .04 & -118 & .32 & .04 \\
\hline
\end{tabular}

Data for soils indicated in figure 4

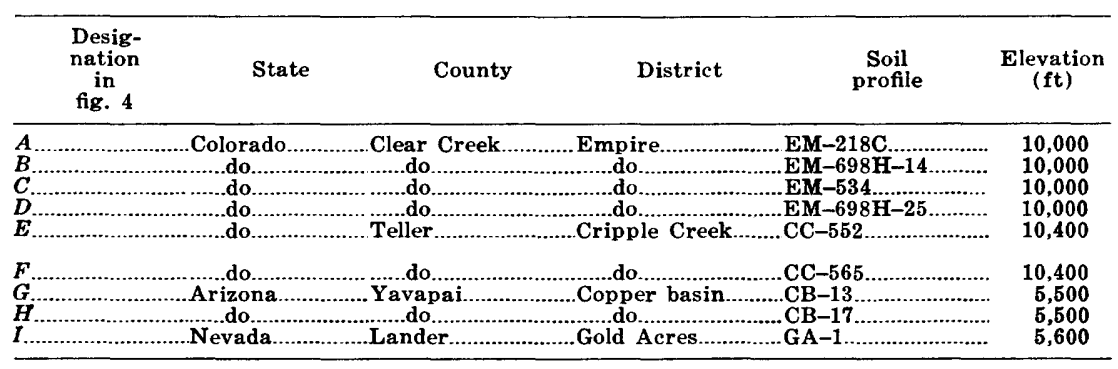

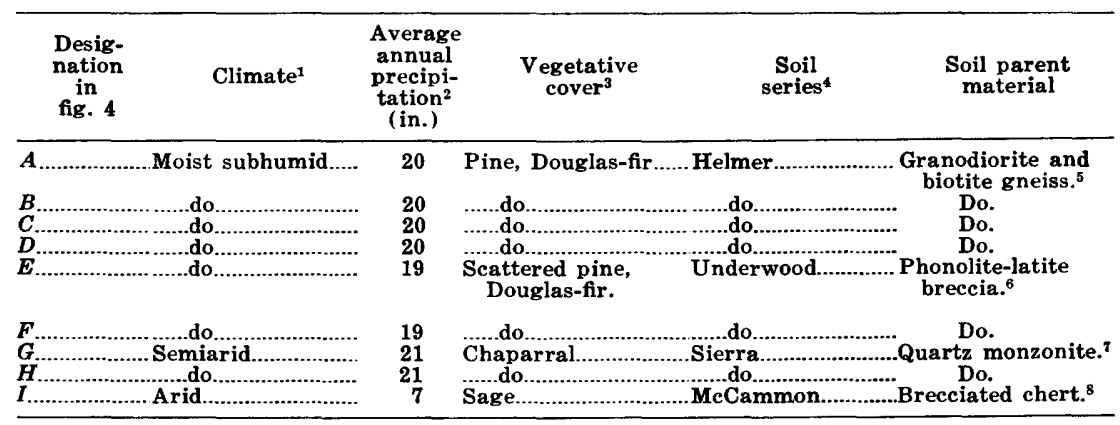

1Thornthwaite (1941).

2U.S. Department of Agriculture (1941).

'Küchler (1967).

${ }^{4}$ U.S. Department of Agriculture (1938)

sBraddock (1969).

'Gott, McCarthy, VanSickle, and McHugh (1967).

'Johnston and Lowell (1961).

sWrucke, Armbrustmacher, and Hessin (1968). 

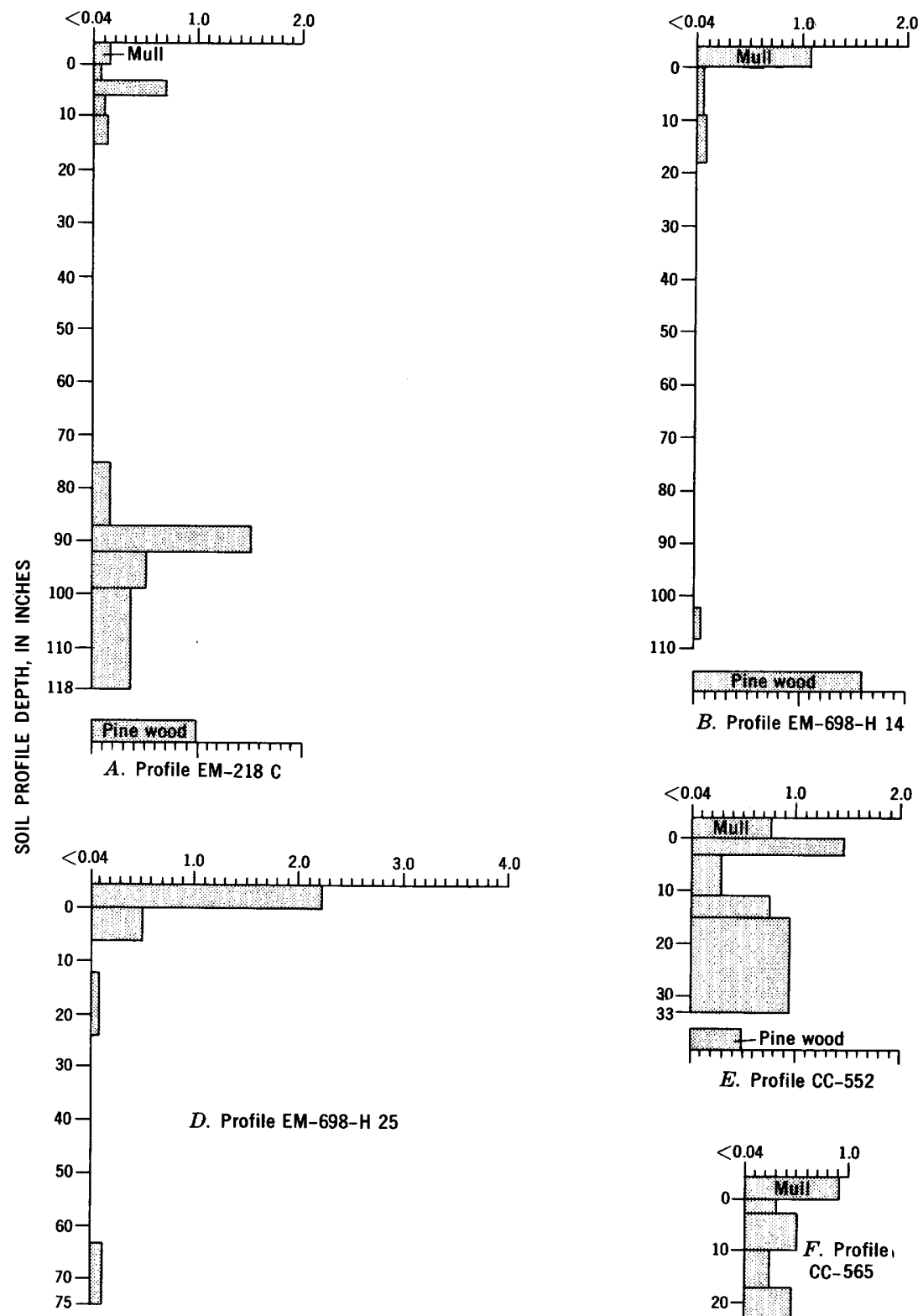

B. Profile EM-698-H 14

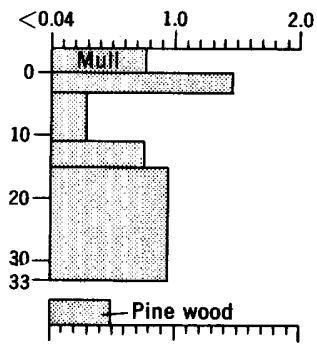

E. Profile CC-552

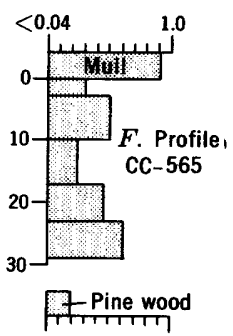

GOLD CONTENT, IN PARTS PER MILLION

FIGURE 4 (above and facing page). - Histograms of gold content of soil profiles and associated vegetation showing high gold values near both the top and bottom of the profiles. 


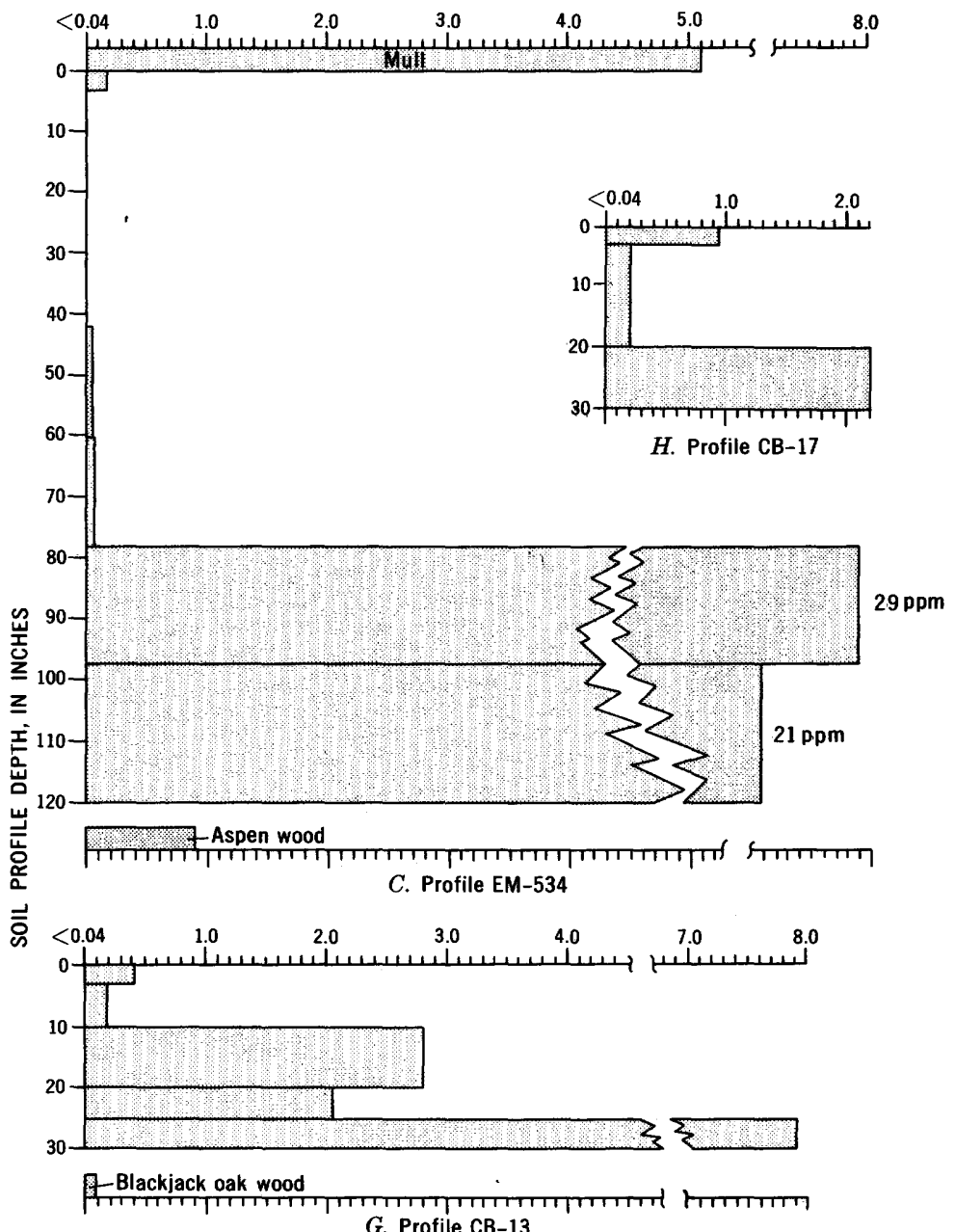

G. Profile CB-13

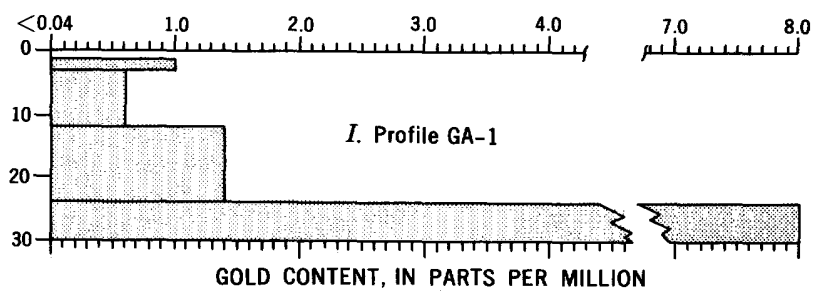

Figure 4. - Continued.

contribute gold to the soil fraction. This positive correlation of gold content between the rock fragments and the soil fraction suggests that vein material is more completely decomposed near the bottom of the soil profile because abrasion during creep or 


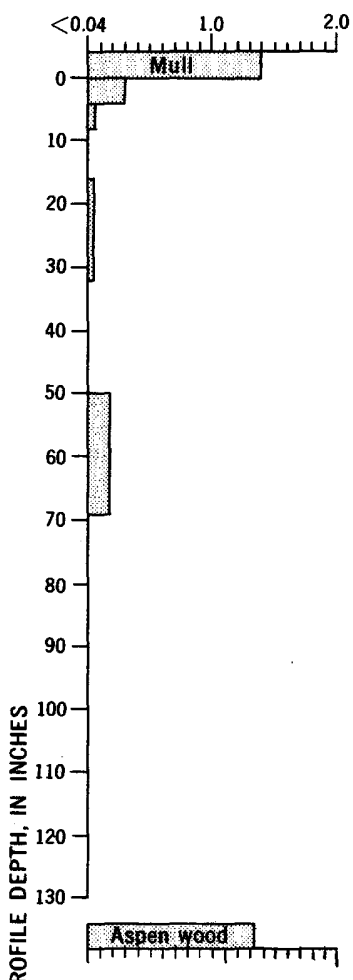

A. Profile EM-314

홍

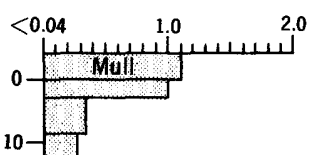

7 Pine wood

E. Profile CC-564
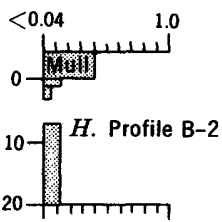
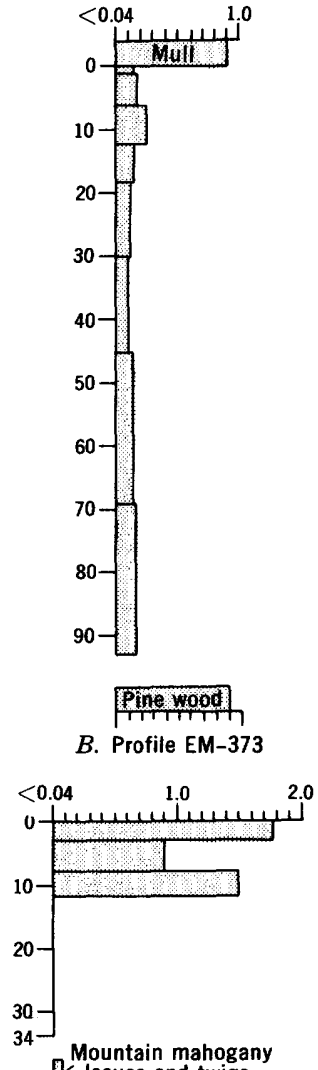

Mountain mahogany
leaves and twigs - Mountain mahogany wood D. Profile U-3
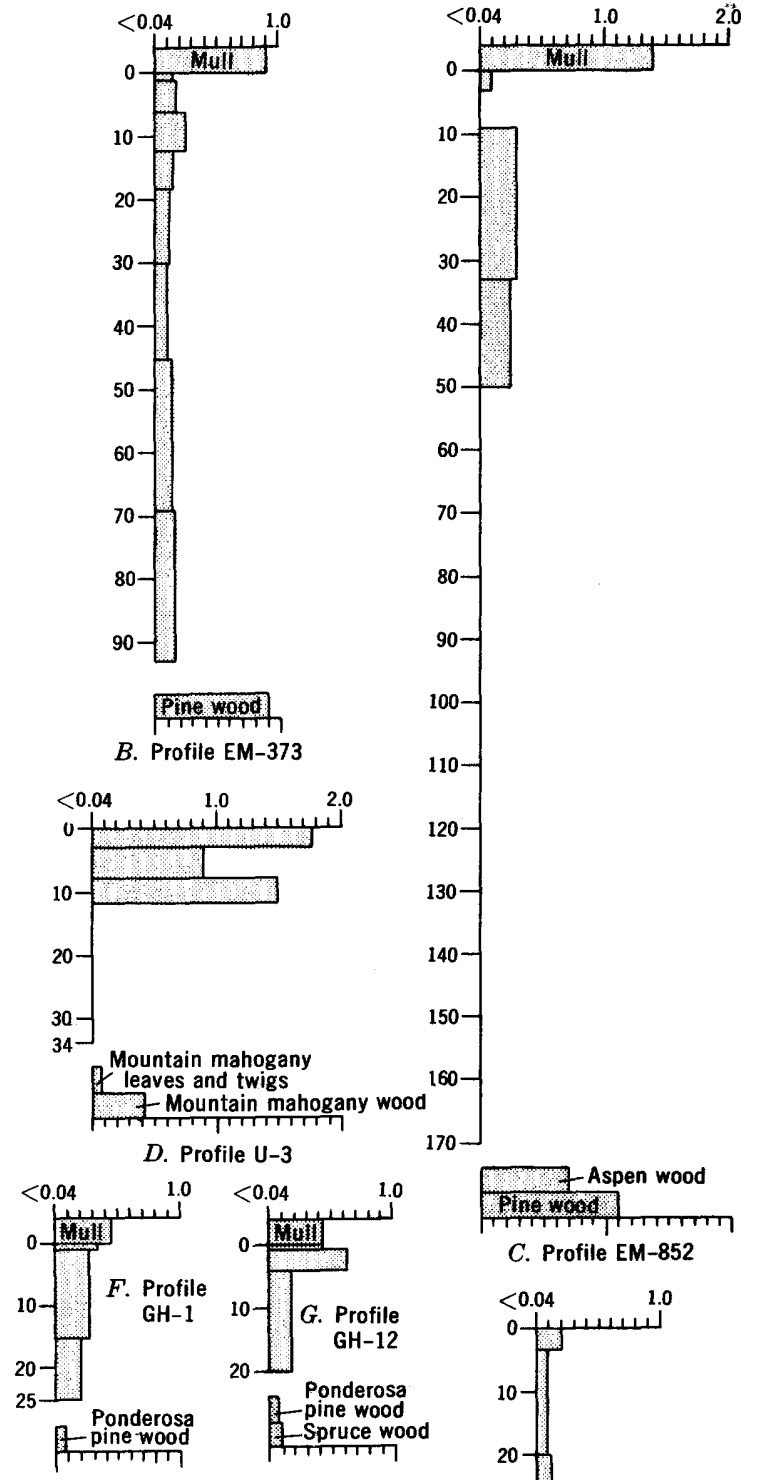

C. Profile EM-852
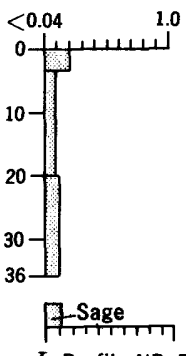

$J$. Profile NB-7

GOLD CONTENT, IN PARTS PER MILLION

FIGURE 5. - Histograms of gold content of soil profiles and associated vegetation showing high gold values near the top of the profiles. 
Duta for soils indicated in figure 5

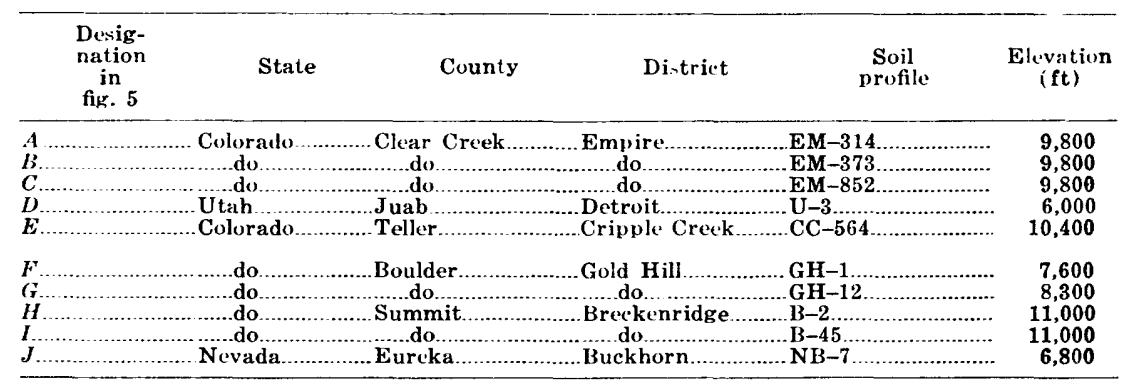

\begin{tabular}{|c|c|c|c|}
\hline $\begin{array}{c}\text { Desig- } \\
\text { nation } \\
\text { in } \\
\text { fig. } 5\end{array}$ & $\begin{array}{l}\text { Average } \\
\text { annual } \\
\text { precipi- } \\
\text { tation } \\
\text { (in.) }\end{array}$ & Vegetative cover ${ }^{3}$ & $\begin{array}{c}\text { Soil parent } \\
\text { material }\end{array}$ \\
\hline A...................... Moist subhumid... & 23 & Pine, Douglas-fir.... & $\begin{array}{r}\text { Helmer................. Granodiorite and } \\
\text { biotite gnt iss. }\end{array}$ \\
\hline 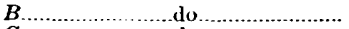 & 20 & 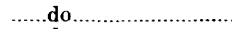 & 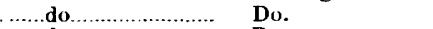 \\
\hline 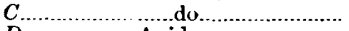 & 20 & .......do & .....do...................... \\
\hline 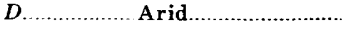 & 7 & Sage $\ldots . . . .$. & $\begin{array}{c}\text { MeCammon .............. Limestone and } \\
\text { dolomite. }\end{array}$ \\
\hline$E \ldots \ldots \ldots \ldots \ldots$ Moist subhumid..... & 19 & $\begin{array}{l}\text { Scattered pine, } \\
\text { Douglas-fir. }\end{array}$ & $\begin{array}{c}\text { Underwood............. Phonolite-latite } \\
\text { breccia. }\end{array}$ \\
\hline (n) do & 20 & \multirow{5}{*}{\multicolumn{2}{|c|}{ 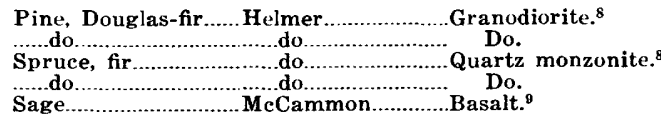 }} \\
\hline$G$. & 20 & & \\
\hline 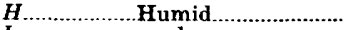 & 22 & & \\
\hline$I$ & 22 & & \\
\hline 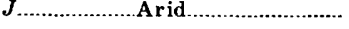 & 9 & & \\
\hline
\end{tabular}

Thornthwaite (1941).

'U.S. Department of Agriculture (1941).

"Küchler (1967).

U.S. Department of Agriculture (1938).

'Braddock (1969).

"McCarthy, Learned, Botbol, Lovering, Watterson, and Turner (1969).

'Gott, McCarthy, VanSickle, and McHugh (1967).

'Lovering and Goddard (1950).

"Wells, Stoiser, and E!liott (1969).

chemical weathering, or both, are more active in this zone than in horizons nearer the surface.

A combination of active breakdown of rock fragments near the bottom of the soil profile and downward migration of gold in the soil is suggested by the distribution of gold in soil profile EM-534 (fig. $4 C$ ). This soil profile, in which two intervals just above the soil-bedrock interface contain 29 and $21 \mathrm{ppm}$ gold, was collected on a hillside near an area where the soil has been placered to obtain gold that has concentrated near the soil-bedrock interface. Gold has been concentrated near the bottom of the soil profile, at least in part, by the downward migration of gold and other heavy constituents which results from the churning action that takes place within the soil during downslope creep. Accelerated breakdown of rock fragments in the lower levels of the soil is also taking place in this soil profile. A composite sample of the two gold-rich intervals was panned, and gold was visible in the panned 


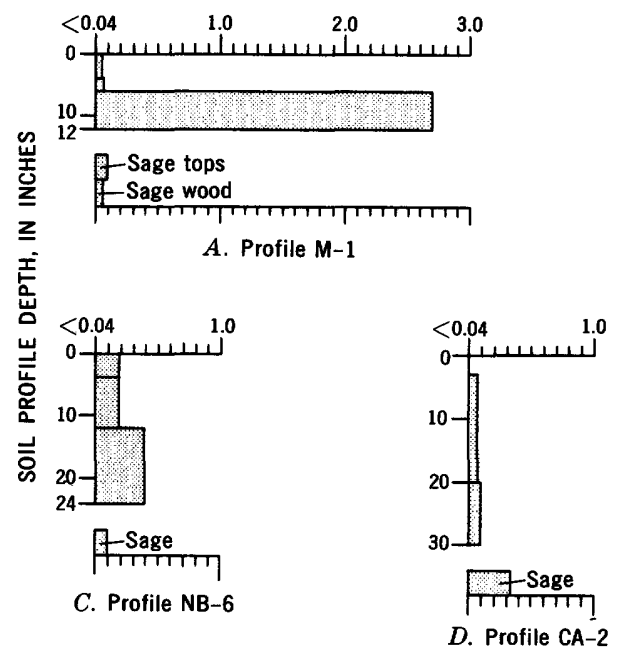

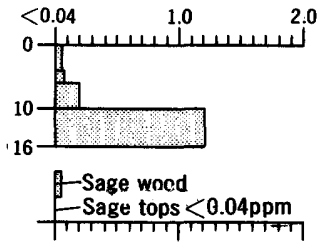

B. Profile $\mathrm{M}-2$

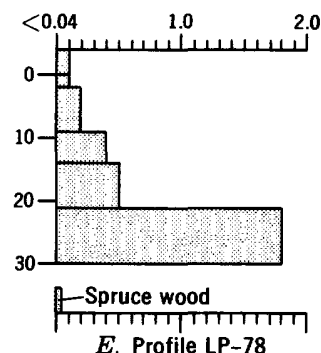

GOLD CONTENT, IN PARTS PER MILLION

FIGURE 6. - Histograms of gold content of soil profiles and associated vegetation showing high gold values near the bottom of the profiles.

Data for soils indicated in figure 6

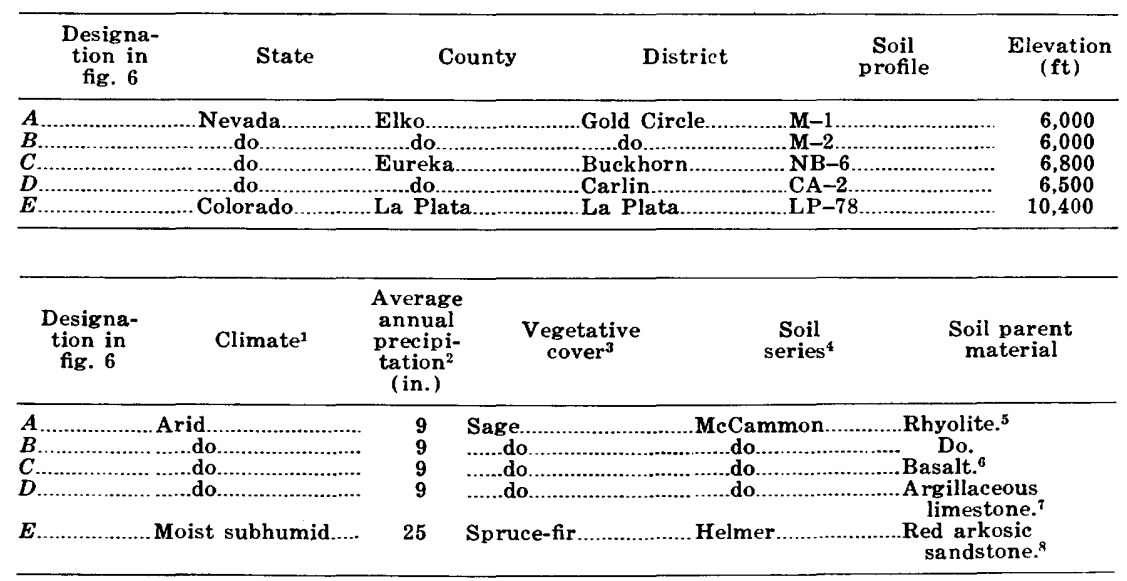

1Thornthwaite (1941).

${ }^{2}$ U.S. Department of Agriculture (1941).
${ }^{3}$ Küchler (1967).

UU.S. Department of Agriculture (1938).

${ }^{5}$ Rott (1931).

Wells, Stoiser, and Elliott (1969).

'Hardie (1966).

${ }^{8}$ Eckel (1949).

heavy-mineral fraction. The tails were recovered and sieved. Gold was determined by analysis in all size fractions from colloidal size to greater than $0.25 \mathrm{~mm}$ in diameter, illustrating the release of gold as the rock fragments weather. The minerals muscovite (and possibly zinnwaldite), chamosite, and a trace of montmorillonite 
were determined in the clay-size fraction by X-ray powder diffraction. These minerals offer further evidence that the soil at this depth undergoes both mechanical and chemical weathering because muscovite and zinnwaldite are the products of mechanical breakdown, whereas chamosite and montmorillonite are products of chemical weathering.

Four of the five soil profiles showing the highest gold values near the bottom of the profile (fig. 6) were collected in arid environments where the concentration of gold in the upper part of the profiles by the biogeochemical cycle is restricted, owing to the relative sparsity of vegetation. The dominant gold concentrating processes which are effective in these environments are the migration of gold downward within the profiles and the dilution of upper soil layers by deposition of barren windblown material.

Low gold content in the middle parts of several of the profiles (figs. $4 \mathrm{~A}, C, E, F, H$ ) may reflect both depletion due to the migration of gold to the bottom of the profile and dilution caused by the addition of barren soil material to gold-bearing material.

The distribution of gold in sieved fractions of six soil profiles (table 32) shows that anomalous concentrations of gold are not necessarily restricted to a single size fraction. The distribution of gold in the size fractions of any soil profile may reflect the character of the associated gold deposits. As an example, wire gold in coarse fragments of quartz-vein material accounts for the relatively high gold content in the $-2.01+1.04-\mathrm{mm}$ and -1.04 $+.501-\mathrm{mm}$ size fractions in the C horizon of profile LP-74. The fact that gold does occur in coarse soil material from place to place demonstrated the necessity either (1) to include in the soil sample all material equal to or less than $2 \mathrm{~mm}$ in diameter, as defined by the U.S. Department of Agriculture (1951, p. 207), or (2) to fractionate several selected soil samples in order to determine which size fraction contains the most gold when collecting soil samples for gold analysis.

\section{MULL AS A SAMPLE MEDIUM IN GEOCHEMICAL EXPLORATION FOR GOLD}

Mull is often an excellent sampling medium for reconnaissance geochemical exploration for gold and other elements. Mull is the partially decomposed plant debris found under trees or shrubs mixed with soil or rock fragments introduced by sheet wash, wind, and the activity of rodents and other animals. It generally occurs as thick, black humus-rich pads mixed with various amounts of mineral matter. The U.S. Department of Agriculture (1951, p. 246 ) classifies such mull as the $A_{0}$ horizon. 
TABLE 32. - Gold content of seven size fractions of soil horizons in six soil profiles

[High gold value in each size fraction is shown in italic. Leaders (...) in figure columns indicate no data available]

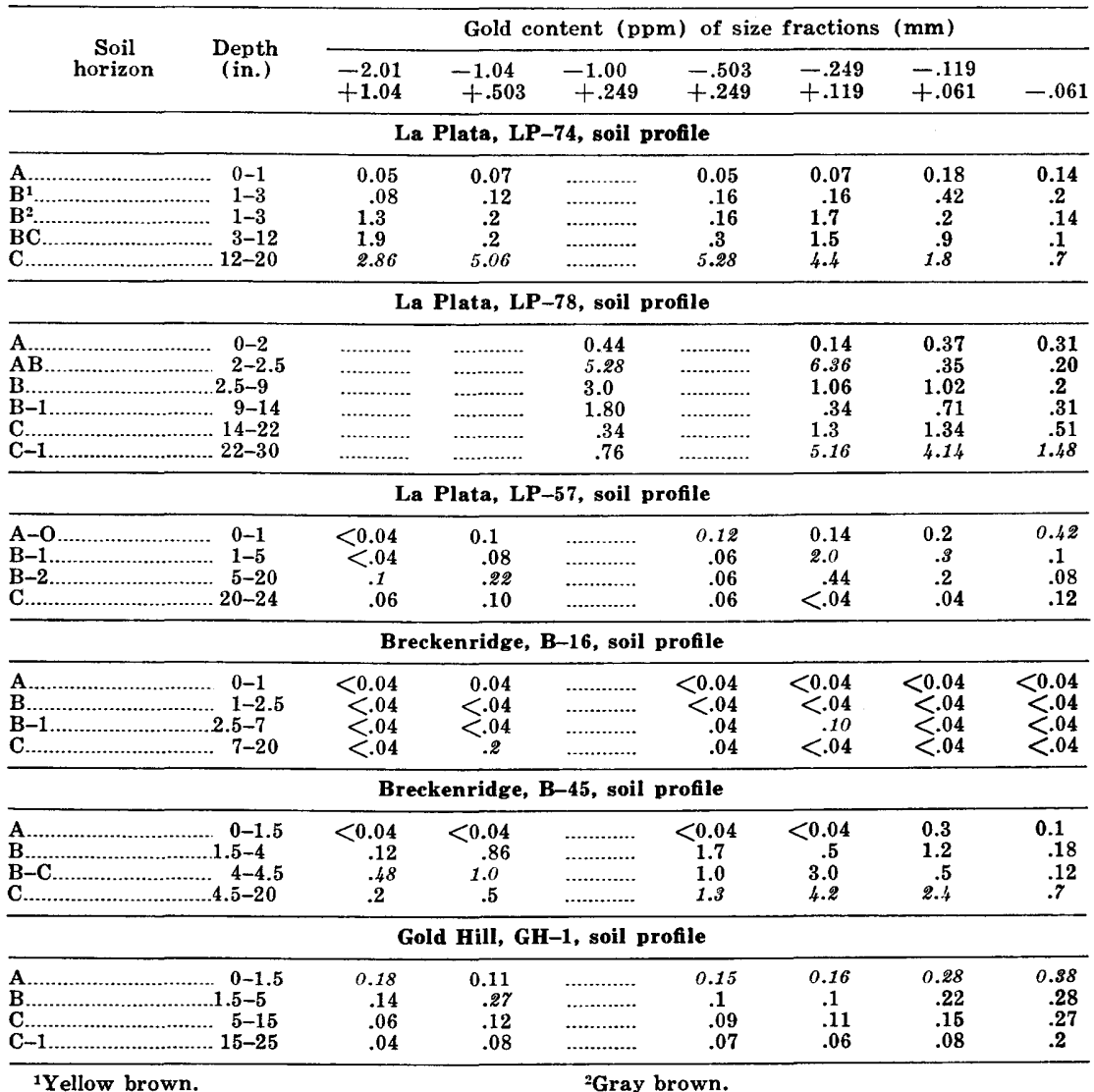

${ }^{2}$ Gray brown.

The presence of gold in humus was observed by Goldschmidt (1937, p. 670) in beech humus from a very old beech and oak forest in Germany. Goldschmidt suggested that a number of elements, including gold, which enter the plant organism through the roots in soil solution and which are eventually deposited on the ground, are immobilized and enriched in this humus layer. A particular advantage of the mull sample is related to the usual occurrence of gold as dispersed particles in the soil and to the tendency of particulate gold under the influence of gravity to migrate downward in the soil and to accumulate in crevices of the underlying bedrock. In analyzing soil, then, one must have very fine gold particles or a great amount of luck to collect a 10-g soil sample that contains gold. In contrast, the humus layer has acted 
as a reductant and concentration medium which retains exceedingly fine gold at the surface that has been accumulated from a large volume of soil by the tree. The relative insolubility of gold drastically limits the portion of the total gold under the plant that is available to the plant roots. One would expect to find easily detectable gold in the humus layer only in those areas where gold is relatively abundant. Its detection in humus suggests the possible presence of gold ores.

Goldschmidt (1954, p. 204) suggested that the concentration of gold in forest humus soil "may be used as an indication of the occurrence of gold in lower levels of the soil." More recently forest humus (mull) has been used successfully as a sampling medium in glacial morainal, colluvial, and alluvial terrains of the Empire district, Colorado (Curtin and others, 1968, 1971), of an area near Stibnite, Idaho (Banister, 1970), and of the Orogrande district, Idaho (Rice, 1970).

An insight into the usefulness of mull samples on essentially residual soils is provided by reconnaissance sampling of mull and underlying soil at intervals of 200 feet on a ridge east of the main Empire district, Clear Creek County, Colo. (figs. 7, 8, 9).

Four sample sites (EM-696-699) on a ridge east of the Empire district are shown in figure 7 . The gold content of soil (depth 3-8 in.) and of the ash of mull at these four sites and the localities of subsequent, more detailed samples are shown in figure 8. The gold contents of mull ash in the subsequent mull samples and of the vein materials obtained by trenching are shown in figure 9 .

The ash of mull at site EM-698 contained $0.62 \mathrm{ppm}$ gold, although no gold $(<0.04 \mathrm{ppm})$ was found in the underlying soil or in the sample of the dump of the adjacent prospect. This anomalous gold content of the mull ash on apparently residual soil was further studied by sampling and trenching, as shown on figures 8 and 9 , to determine the source of the anomaly.

The area is underlain by lenses of biotite gneiss that have been intruded by Boulder Creek Granite and small dikes of pegmatite. The lenses of biotite gneiss strike west to northwest and dip about $30^{\circ} \mathrm{NE}$. The numerous small pegmatite dikes and associated small migmatite zones occur principally at or near the granite-gneiss contact.

The primary vein, revealed by a small mining operation and by our trenching with a backhoe, occupies a small shear zone that follows one of the pegmatite dikes for part of its length. The vein strikes about $\mathrm{N} .70^{\circ} \mathrm{W}$. and dips steeply to the east. This vein, which is composed of disseminated sulfides in a matrix of finegrained quartz, is about $3-12$ inches thick. The country rock is 


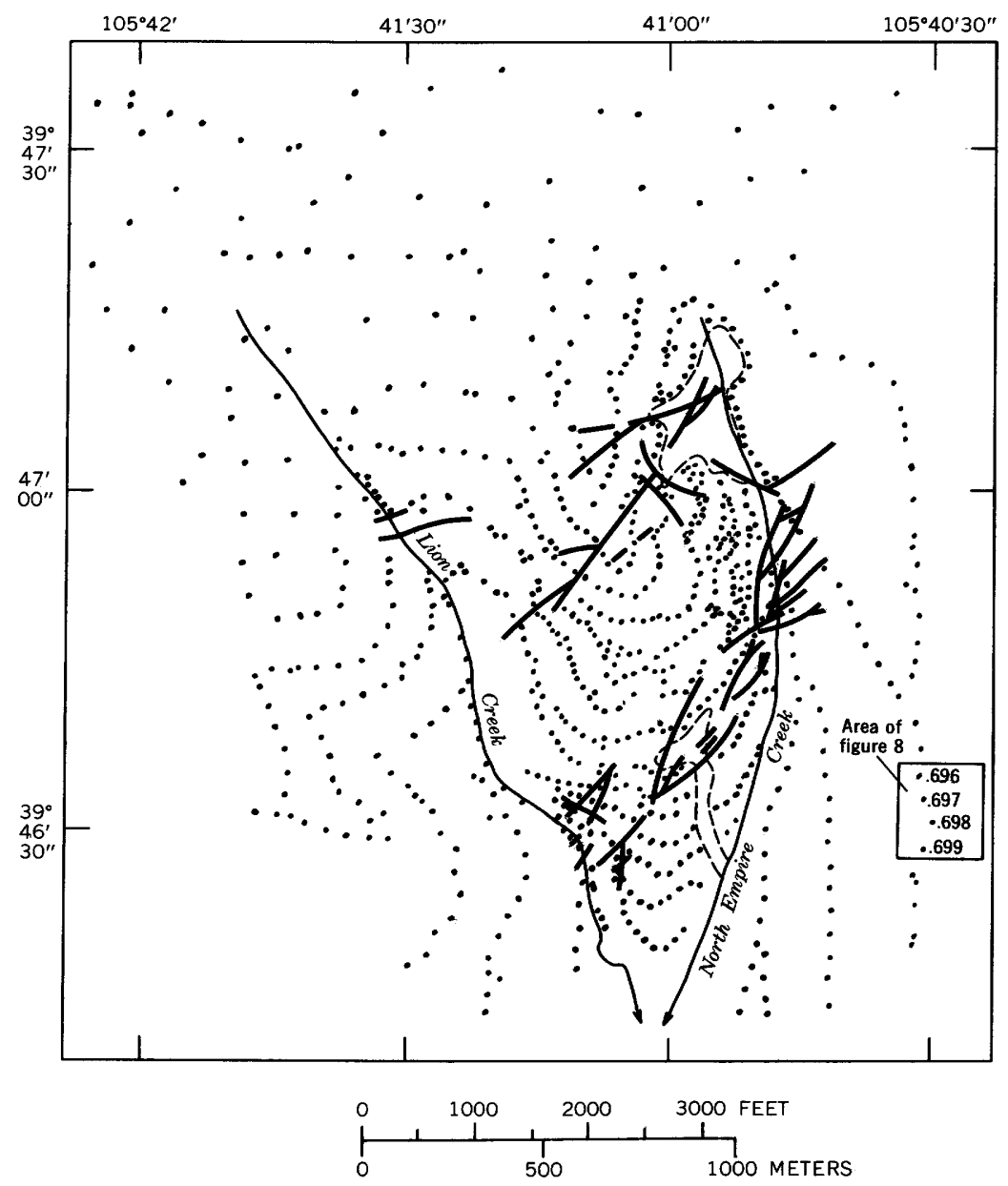

Figure 7. - Sample locality map of the Empire district, Colorado, showing location of site EM-698 (rectangle). Heavy lines are veins. Dashed lines indicate placered areas.

argillized adjacent to the vein and contains some disseminated sulfides.

The granite and biotite gneiss are weathered to a sandy loam to depths greater than 9 feet. The pegmatite dikes and silicified veins are much more resistant to weathering and remain as boulders of many sizes dispersed locally in the matrix of weathered country rock.

The soils here, as in the rest of the district, are inceptisols (U.S. Department of Agriculture, 1960, p. 136). Under the mull layer is a gray ash-textured layer 1-3 inches thick. Below this 

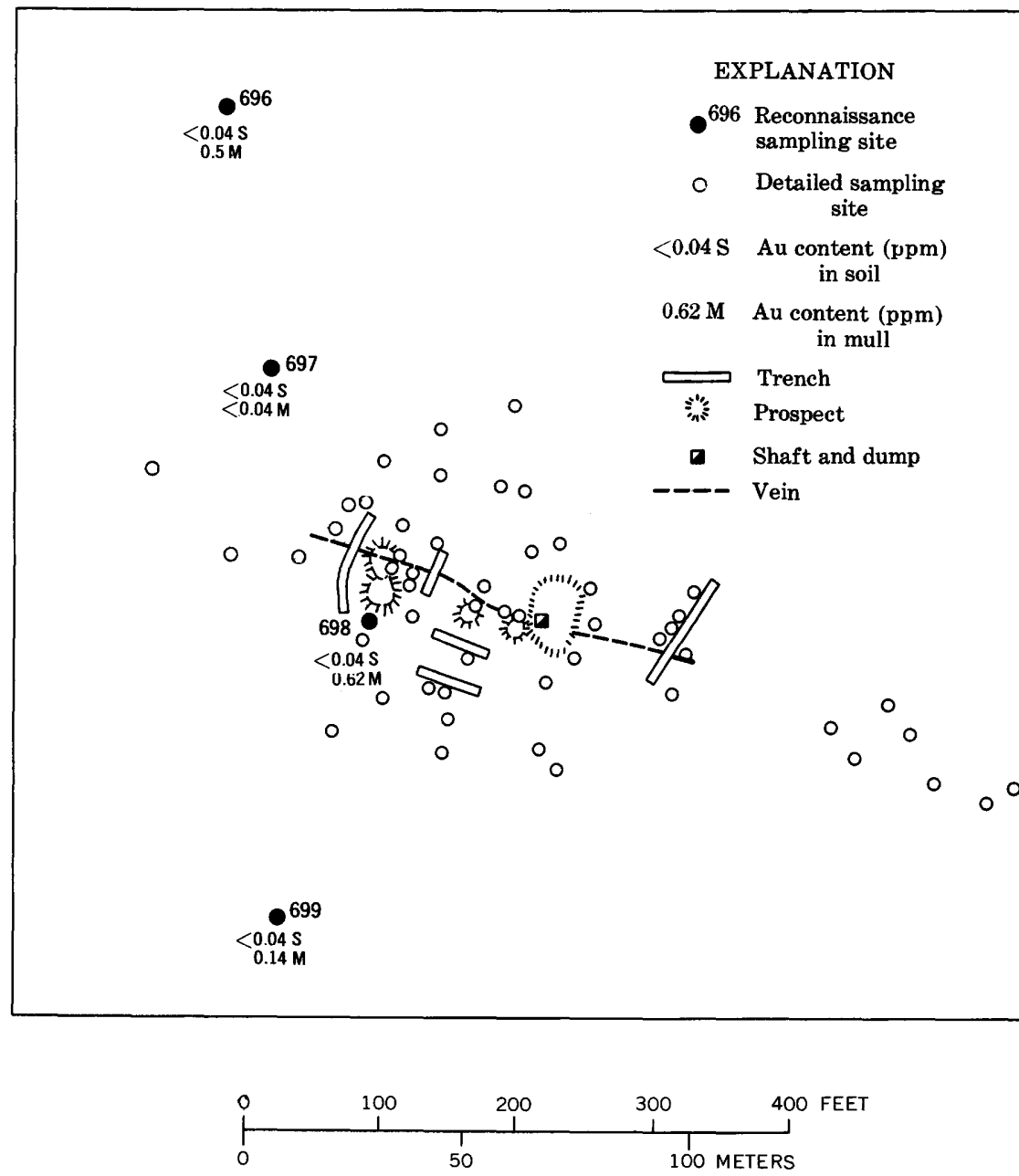

Figure 8. - Sample locality map showing relationship of detailed sampling around site EM-698 and reconnaissance sampling, Empire district, Colorado.

surface layer is a yellow to yellow-brown gravelly sandy loam that varies little in texture or color from a depth of 3 inches to bedrock.

The area is in a subalpine zone, at an elevation of 10,000 feet, with a vegetative cover of lodgepole pine (Pinus contorta), aspen (Populus tremuloides), kinnikinick (Arctostaphylos uva-ursi), and subalpine grasses. It is covered with snow at least 6 months of the year. Rain and sleet showers are frequent throughout the summer.

Mull samples were collected at 60 sites (fig. 9) under 52 lodgepole pine trees and 8 aspen trees in an area 1,500 feet long and 

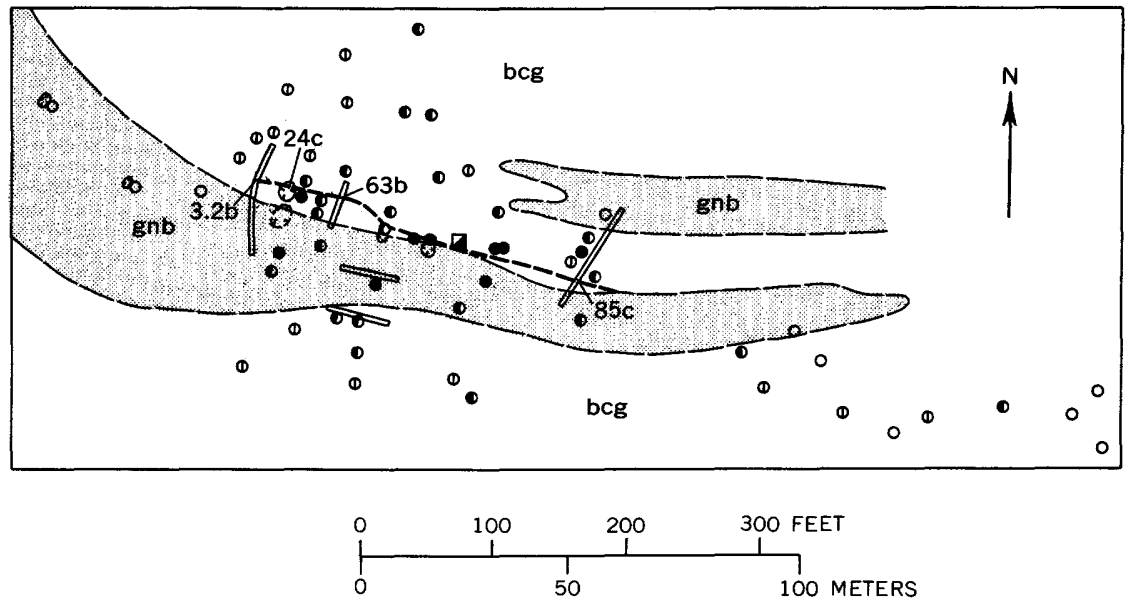

EXPLANATION

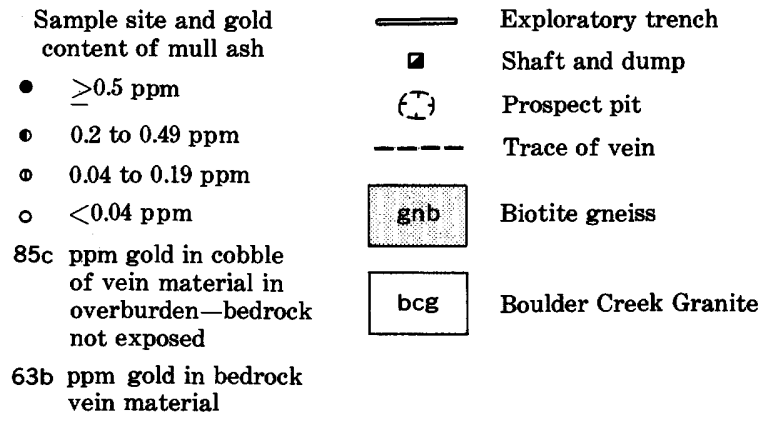

FIGURE 9. - Geochemical and geologic map of locality EM-698, showing gold content of mull ash and vein material, Empire district, Colorado.

600 feet wide. Soil samples were collected at spade depth (6-8 in.) directly under each mull sample site.

Gold was not detected $(<0.04 \mathrm{ppm})$ in 10 of the ashes of the 60 mull samples (fig. 9) and was $0.5 \mathrm{ppm}$ or more in 9 samples collected along the trace of the vein. In contrast, gold was not detected in 42 of the 60 soil samples and was $0.5 \mathrm{ppm}$ or more in only 1 sample.

Trenching with a backhoe revealed a mineralized vein in bedrock in the center trench (fig. 9) that was 2-4 inches thick and contained $63 \mathrm{ppm}$ gold. In the western trench the gold content was only $3.2 \mathrm{ppm}$. Float in the eastern trench contained $85 \mathrm{ppm}$ gold. Obviously the gold mineralization located by intensive study of reconnaissance site EM-698 is not extensive. The point of interest from this sampling is that a relatively small vein can be the source of a widespread anomaly in the mull samples. 
The biological source of the gold in the mull is substantiated by the presence of gold in the ash of various parts of the lodgepole pine and aspen growing near the vein (table 33). It is especially significant that the ash of clean interior wood of both the lodgepole pine and the aspen contained $1 \mathrm{ppm}$ or more of gold. This, in our opinion, removes any doubts about gold being taken up from soil solutions by these trees.

TABLE 33. - Gold content of the ash of various parts of lodgepole pine and aspen growing near gold-bearing vein

\begin{tabular}{|c|c|c|c|c|c|}
\hline $\begin{array}{l}\text { Sample No. } \\
\text { EM-698- }\end{array}$ & $\begin{array}{l}\text { Description of } \\
\text { ash sample }\end{array}$ & $\begin{array}{c}\text { Gold in } \\
\text { ash (ppm) }\end{array}$ & $\begin{array}{c}\text { Sample No. } \\
\text { EM-698- }\end{array}$ & $\begin{array}{l}\text { Description of } \\
\text { ash sample }\end{array}$ & $\begin{array}{c}\text { Gold in } \\
\text { ash (ppm) }\end{array}$ \\
\hline $\begin{array}{l}25 \\
15 \\
25 \\
15 \\
15 \\
14 \\
25\end{array}$ & 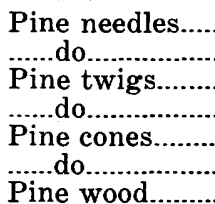 & $\begin{array}{l}0.08 \\
.16 \\
.3 \\
.82 \\
.22 \\
.40 \\
1.96\end{array}$ & $\begin{array}{l}15 \\
25 \\
15 \\
25 \\
25 \\
25 \\
25\end{array}$ & $\begin{array}{l}\text { Pine wood........ } \\
\text { Pine bark...... } \\
\text { Pindo root wood. } \\
\text { Pine ron leaves.... } \\
\text { Aspen wood..... } \\
\text { Aspen bark...... }\end{array}$ & $\begin{array}{l}1.6 \\
.39 \\
.75 \\
3.0 \\
<.04 \\
1.0 \\
.1\end{array}$ \\
\hline
\end{tabular}

The original sample (EM-698H) of mull containing $0.63 \mathrm{ppm}$ gold was collected 50 feet from this minor vein. This sensitivity to gold-bearing rock strongly suggests that no important gold deposits will be missed by reconnaissance sampling with mull. In contrast, the underlying soil was much less sensitive to the local presence of gold.

\section{SUMMARY OF CONCLUSIONS}

The chemistry of gold is the chemistry of its complex compounds. The stability of complex gold anions is reflected in the ease with which gold metal is oxidized in the presence of the complexing ion. The order of increasing ease of oxidation of gold to form the corresponding gold complex anion studied in this report is $\mathrm{Cl}^{-1}, \mathrm{Br}^{-1}, \mathrm{CNS}^{-1}, \mathrm{I}^{-1}$, and $\mathrm{CN}^{-1}$, with $\mathrm{S}_{2} \mathrm{O}_{3}{ }^{-2}$ probably between $\mathrm{CNS}^{-1}$ and $\mathrm{I}^{-1}$.

The removal of gold from solution by various minerals either by sorption or more probably by reduction of the gold complex to yield gold metal showed a suspectibility to removal of $\mathrm{AuCl}_{4}-1$ $>\mathrm{AuBr}_{4}{ }^{-2}>\mathrm{AuI}_{2}{ }^{-1}>\mathrm{Au}(\mathrm{CN})_{2}{ }^{-1}>\mathrm{Au}(\mathrm{CNS})_{4}{ }^{-1}>\mathrm{Au}\left(\mathrm{S}_{2} \mathrm{O}_{3}\right)_{2}{ }^{-3}$. A marked difference in stability of the halide complexes to the cyanide, thiocyanate, and thiosulfate complexes was particularly evident; the halide complexes were much less stable and, therefore, much less mobile in a natural environment.

A study of the absorption of gold by plants showed a strong tendency for the reduction of the halides by plant roots. Colloidal gold was not absorbed by the plants used in these experiments, although colloidal gold has been suggested as the probable form 
of gold taken up by plants. The most readily absorbed complex was the cyanide.

The solubility of gold in acid halide solutions also shows an increasing ease of solution with increasing stability of the complex. Thus, gold chloride is readily formed in strongly acid solutions in the presence of manganese dioxide; gold bromide is formed in acid solution in the absence of manganese dioxide but is more readily dissolved in the presence of manganese dioxide; however, with gold iodide, the solution of gold is inversely proportional to the amount of manganese dioxide present, being highest in the absence of manganese dioxide.

A comparison of the solubility of gold in the input solutions used in leaching copper from porphyry copper ore to which a given amount of chloride, bromide, or iodide has been added shows increasing solubility of gold from chloride to iodide; however, for a given concentration of the halide the solubility of gold decreases with increasing iron, aluminum, and copper. Some gold dissolved in the input solution would be lost from solution in the output solution. Input chloride solutions capable of dissolving gold failed to maintain gold in solution in the presence of an oxidized Carlin gold ore. The reduction of gold chloride by many minerals, plus the complexing of chloride by iron and copper, hampers the recovery of gold from copper ores by present leaching processes. The lack of recovery of gold from copper ores by leaching processes will greatly decrease the production of gold in the United States if present leaching processes gain wide use.

To dissolve about the same amount of gold in a given time ( $1.5 \mathrm{mg} / \mathrm{l}$ in 3 weeks) in input leach solutions, the solutions must also contain $1,800 \mathrm{ppm}$ chloride ion, or $400 \mathrm{ppm}$ bromide ion, or $13 \mathrm{ppm}$ iodide ion, giving an equivalent effectiveness of $100 \mathrm{Cl}^{-1}$ to $22 \mathrm{Br}^{-1}$ to $0.7 \mathrm{I}^{-1}$. The relative crustal abundance of these elements is $100 \mathrm{ppm} \mathrm{Cl}$ to $1.3 \mathrm{ppm} \mathrm{Br}$ to $0.24 \mathrm{ppm} \mathrm{I}$. Thus, considerable enrichment of bromine and iodine would be required for these elements to be as effective as chloride in solubilization of gold in acid solutions. Bromine and especially iodine are enriched in certain plants and the leaching of plant residues gives rise to unusual concentration of these halides. Iodine leached from kelp has produced waters in Java that contain $150 \mathrm{ppm}$ iodine; they also contain $68 \mathrm{ppm}$ bromine. Organic-rich soils of Japan contain as much as $850 \mathrm{ppm}$ bromine. Gold chloride, gold bromide, and gold iodide, therefore, may be formed locally under unusual but possible circumstances. When they are formed, they are readily decomposed by slight changes in their surroundings; consequently, they are transient forms. 
The thiosulfate ion is a metastable species that can be formed by the action of water on native sulfur in basic solutions, by the reaction of hydrogen sulfide with oxygen, and by the catalyzed reaction of the sulfide ion with oxygen in soils by the enzyme oxidase. The thiosulfate anion as a complex former with gold, therefore, may be considered a transition anion from the simple single-element halides to the complex anions largely of biological origin.

Gold is soluble in thiosulfate solution over a wide range of hydrogen ion concentration. It is particularly of interest that gold is soluble as the gold thiosulfate in the normal $\mathrm{pH}$ range of soils and that once gold thiosulfate is formed it is remarkably stable. In the weathering of pyritic gold ores in limestones, the gold may be mobilized as the thiosulfate.

The formation of gold thiocyanate takes place readily over a wide range of $\mathrm{pH}$. Free gold is dissolved in the presence of oxygen and thiosulfate, but gold in massive pyrite and in gold telluride is not attacked. The thiocyanate ion is of biochemical origin and is relatively rare. In microsystems within the soil it may reach concentrations adequate for complexing gold, but it does not seem a particularly important facet in the solution of gold.

Gold cyanide offers the most feasible form of soluble gold in soils. Gold reacts with oxygen in the presence of the cyanide ion to form a stable complex. The presence of the cyanide ion in soils is widespread and often of considerable concentration. Over 1,000 species of plants are known to contain cyanogenetic substances, as do many arthopods and moths; certain fungi release gaseous hydrogen cyanide in remarkably large volumes. A few varieties of flax excrete significant quantities of hydrogen cyanide into the soil from their root system. Nutrient solution in which these varieties were grown contained as much as $37 \mathrm{mg}$ of hydrogen cyanide per plant. In order to determine the abundance of plant species that are cyanogenic, plants were sampled from the Front Range of the Rocky Mountains in Colorado to north-central Nevada and less completely in some other areas. Of the 150 species tested, 116 species ( 78 percent) gave no test for cyanide, 15 species (10 percent) gave questionably positive tests for cyanide, and 19 species (12 percent) gave positive tests for cyanide. Leaf gold was dissolved by an aqueous suspension of macerated plant species which gave positive tests for cyanide.

The fact that cyanide, the byproduct of many life processes, forms such a strong complex with gold would be unique if cyanide were, in fact, the only organic ion formed by natural processes that produced stable gold compounds. The work reported in the 
present paper by Kenneth G. Doxtader on solubilization of gold by microorganisms and organic substances demonstrates the need for more careful research on the solution of gold by the complexing action of naturally occurring organic substances. It is in this area that knowledge of the behavior of gold in the weathering cycle is notably lacking. An organic substance might be found which has the complexing property of cyanide but which lacks the poisonous character of cyanide; it would be a boon to the recovery of gold from low-grade deposits.

The analytical determination of gold in geologic materials is made difficult because of the strong probability that a representative sample is not available to the analyst. A relative standard deviation of less than 50 percent cannot be obtained on $10 \mathrm{~g}$ subsamples if the gold particles are greater than $0.01 \mathrm{~mm}$ in diameter. Gold wires of a few millimeters in length and consisting of less than $1 \mathrm{ppm}$ of the sample are so few that the chances of finding one piece of gold in a 10-g sample are remote. With few exceptions the materials analyzed in this work contained fine gold, and, therefore, the results are reasonably reproducible.

Gold in some soluble form, perhaps as gold cyanide, is absorbed by plants but is not used as a nutrient by plants. It is therefore found accumulating as a reject, like barium, in the woody parts of the plant. The decomposition of plant debris results in the reduction of the gold in the plant material, and gold accumulates in the humus horizon of the soil. This horizon, commonly mixed with colluvial inorganic material, constitutes what we have called mull, and mull has been proved to be a very satisfactory sample for gold exploration. A vein only a few inches thick was located by mull sampling at 200 -foot intervals on a ridgetop; the closest reconnaissance sample was more than 50 feet from the gold-bearing vein.

The distribution of gold within soil profiles may be grouped in three categories: (1) high gold content in the surface humus horizon; (2) high gold content in the surface and bottom horizons; (3) high gold content in the bottom horizon.

Gold may become enriched in the surface soil because of sheet erosion removing lighter material. It may also become enriched by biogeochemical cycling of gold, a process in which gold is leached from the soil and bedrock, is absorbed by the vegetation, and is eventually concentrated in the mull and upper layers of the soil as the vegetation decays. This process is presumed to be the dominant one in those profiles in which the gold content is high in the ash of mull.

The high density of gold particles that permits the residual 
enrichment of the particles in sheet erosion also permits their accumulation at bedrock surfaces by gravity separation in the soil profile by much the same process as in stream sediments. When gravity separation is combined with biochemical or erosional surface enrichment one finds soil profiles with high gold content at both the surface and the rock bottom.

When no biogeochemical or erosional enrichment of the surface soil is occurring, the gravity effect is dominant and the soil shows high gold content only near bedrock or at the interface with a clay pan.

The distribution of gold with particle size is a function of the completeness of the weathering of the ore. Inasmuch as many gold ores are emplaced with silicification, the ore may be more resistant to weathering than are the wallrocks. In such places, fine gold may be enclosed in coarse particles in the soil. This fact must be considered in soil or stream sampling in gold exploration.

\section{LITERATURE CITED}

American Cyanamid Co., 1965a, [Au/Ag map] Metal production for the calendar year 1965: Wayne, N.J., Am. Cyanamid Co., 1 p. $1965 \mathrm{~b}$, [ $\mathrm{Cu}$ map] 1965 copper production of mines producing 7,500 (or more) short tons of metal in concentrates: Wayne, N.J., Am. Cyanamid Co., 1 p.

Armstrong, E. F., and Armstrong, K. F., 1931, The glycosides: London, Longmans, Green and Co., $123 \mathrm{p}$.

Arntson, R. H., Dickson, F. W., and Tunell, George, 1960, Systems $\mathrm{S}-\mathrm{Na}_{2} \mathrm{O}-\mathrm{H}_{2} \mathrm{O}$ and $\mathrm{S}-\mathrm{H}_{2} \mathrm{O}-$ Application to the mode of origin of natural alkaline polysulfide and thiosulfate solutions: Am. Jour. Sci., v. 258, p. 574-582.

Banister, D. P., 1970, Geochemical investigations for gold, antimony, and silver at Stibnite, Idaho: U.S. Bur. Mines Rept. Inv. 7417, 7 p.

Beall, J. V., 1965, Southwest copper - A position survey: Mining Eng., v. 17, no. 10 , p. 77-92.

Bemmelen, R. W. van, 1949, Economic geology, v. 2 of The geology of Indonesia: The Hague, Govt. Printing Office, $265 \mathrm{p}$.

Blatchley, W. S., 1903, The mineral waters of Indiana: Indiana Dept. Geology and Nat. Resources 26th Ann. Rept., p. 11-158.

Blum, M. S., and Woodring, J. P., 1962, Secretion of benzaldehyde and hydrogen cyanide by the millipede Pachydesmus crassicutis (Wood): Science, v. 138 , p. 512-513.

Braddock, W. A., 1969, Geology of the Empire quadrangle, Grand, Gilpin, and Clear Creek Counties, Colorado: U.S. Geol. Survey Prof. Paper 616, $56 \mathrm{p}$.

Brokaw, A. D., 1910, The solution of gold in the surface alterations of ore bodies: Jour. Geology, v. 18, p. 321-326.

Charlot, G., 1954, Qualitative inorganic analysis - A new physicochemical approach (translated by R. C. Murray) : New York, John Wiley \& Sons, Inc., $691 \mathrm{p}$. 
Chilean Iodine Educational Bureau, 1956, Geochemistry of iodine: London, Chilean Iodine Educational Bur., 150 p.

Chukhrov, F. V., 1947, Gold migration in the oxidation zone: Akad. Nauk SSSR Izv. Ser. Geol., no. 4, p. 117-126. (In Russian with English abs.)

Clarke, F. W., 1924, The data of geochemistry [5th ed.] : U.S. Geol. Survey Bull. $770,841 \mathrm{p}$.

Clifton, H. E., Hunter, R. E., Swanson, F. J., and Phillips, R. L., 1969, Sample size and meaningful gold analysis: U.S. Geol. Survey Prof. Paper 625-C, $17 \mathrm{p}$.

Cline, J. D., and Richards, F. A., 1969, Oxygenation of hydrogen sulfide in seawater at constant salinity, temperature, and $\mathrm{pH}$ : Environmental Sci. and Technology, v. 3, p. 838-843.

Cloke, P. L., and Kelly, W. C., 1964, Solubility of gold under inorganic supergene conditions: Econ. Geology, v. 59, no. 2, p. 259-270.

Conn, E. E., 1969, Cyanogenic glycosides: Agr. and Food Chemistry, v. 17, no. 3, p. 519-526.

Conn, E. E., and Butler, G. W., 1969, The biosynthesis of cyanogenic glycosides and other simple nitrogen compounds, in Harborne, J. B., and Swain, Tony, eds., Perspectives in phytochemistry — Proc. Phytochemical group Symposium, Cambridge, England: London, Academic Press, p. 47-74.

Correns, C. W., 1956, The geochemistry of the halogens, [chap.] 7, in v. 1, of Ahrens, L. H., Rankama, Kalervo, and Runcorn, S. K., eds., Physics and chemistry of the earth: New York, Pergamon Press, p. 181-233.

Cotton, F. A., and Wilkinson, G., 1962, Advanced inorganic chemistry - A comprehensive text: New York, Intersci. Publishers, $959 \mathrm{p}$.

Couch, J. F., and Briese, R. R., 1940, Cyanogenesis and enzyme activity in sorghum varieties: Washington Acad. Sci. Jour., v. 30, no. 10, p. 413-421.

Couch, J. F., Briese, R. R., and Martin, J. H., 1939, Hydrocyanic acid content of sorghum varieties: Washington Acad. Sci. Jour., v. 29, no. 4, p. 146-161.

Curtin, G. C., Lakin, H. W., Hubert, A. E., Mosier, E. L., and Watts, K. C., 1971, Utilization of mull (forest humus layer) in geochemical exploration in the Empire district, Clear Creek County, Colorado: U.S. Geol. Survey Bull. 1278-B, 39 p.

Curtin, G. C., Lakin, H. W., Neuerburg, G. J., and Hubert, A. E., 1968, Utilization of humus-rich forest soil (mull) in geochemical exploration for gold: U.S. Geol. Survey Circ. 562, 11 p.

Day, A. L., and Allen, E. T., 1925, The volcanic activity and hot springs of Lassen Peak: Carnegie Inst. Washington, $190 \mathrm{p}$.

Deer, W. A., Howie, R. A., and Zussman, J., 1966, An introduction to the rockforming minerals: New York, John Wiley \& Sons, Inc., 528 p.

Dillemann, Georges, 1959, Composes cyanogenetiques, in Rulhand, Wilhelm, ed., Handbuch der Pflanzenphysiologie: Berlin, Springer, v. 8, p. 1050-1075.

Eckel, E. B., 1949, Geology and ore deposits of the La Plata district, Colorado, with sections by J. S. Williams, F. W. Galbraith and others: U.S. Geol. Survey Prof. Paper 219, 179 p.

Eisner, T., Eisner, H. E., Hurst, J. J., Kafatos, F. C., and Meinwald, J., 1963, Cyanogenic glandular apparatus of a millipede: Science, v. 139, p. 12181220.

Emmons, W. H., 1917, The enrichment of ore deposits: U.S. Geol. Survey Bull. 625,530 p.

Filer, T. H., Jr., 1965, Damage to turfgrasses caused by cyanogenic compounds produced by Marasmius oreades, a fairy ring fungus: Plant Disease Reporter, v. 49 , no. 7, p. 571-574. 
Fleischer, Michael, 1971, Glossary of mineral species, 1971, with appendix by J. S. White, Jr.: Mineralog. Rec., Inc., 121 p.

Gale, C. W., 3d, 1971, The effect of a strong oxidizing environment on the stability of the gold iodide complex, in Geological Survey research 1971: U.S. Geol. Survey Prof. Paper 750-B, p. B140-B142.

Garrels, R. M., 1960, Mineral equilibria at low temperatures and pressure: New York, Harper \& Brothers, Publishers, 254 p.

Garrels, R. M., and Naeser, C. R., 1958, Equilibrium distribution of dissolved sulphur species in water at $25^{\circ} \mathrm{C}$ and 1 atm total pressure: Geochim. et Cosmochim. Acta, v. 15, p. 113-130.

Goldschmidt, V. M., 1937, The principles of distribution of chemical elements in minerals and rocks: Chem. Soc. (London) Jour., p. 655-673.

1954, Geochemistry: Oxford, Clarendon Press, 730 p.

Gosling, A. W., Jenne, E. A., and Chao, T. T., 1971, Gold content of natural waters in Colorado: Econ. Geology, v. 66, no. 2, p. 309-313.

Gott, G. B., McCarthy, J. H., Jr., VanSickle, G. H., and McHugh, J. B., 1967, Distribution of gold, tellurium, silver, and mercury in part of the Cripple Creek district, Colorado: U.S. Geol. Survey Circ. 543, 9 p.

Granger, H. C., and Warren, C. G., 1969, Unstable sulphur compounds and the origin of roll-type uranium deposits: Econ. Geology, v. 64, no. 2, p. 160-171.

Haber, Fritz, 1928, Das Gold im Meere, in Defant, A. [ed.], Verhandlungen der Ozeanographischen Konferenz, Hundertjahrfeier, 1928: Gessel, Erdkunde Berlin Zeitschr., Ergänzungsheft 3, p. 3-12.

Hardie, B. S., 1966, Carlin gold mine, Lynn district, Nevada, in AIME Pacific Southwest Mineral Industry Conf., Sparks, Nev., 1965, Papers, Pt. A : Nevada Bur. Mines Rept. 13, p. 73-83.

Jacobson, C. A., ed., 1949, Encyclopedia of chemical reactions, v. 3: New York, Reinhold Publishing Corp., 842 o.

Jaenicke, Johannes, 1935, Habers Forschungen über das Goldvorkommen im Meerwasser: Naturwissenschaften, v. 23, no. 4, p. 57-63.

Johnston, W. P., and Lowell, J. D., 1961, Geology and origin of mineralized breccia pipes in copper basin, Arizona: Econ. Geology, v. 56, no. 5, p. 916-940.

Jones, D. A., Parsons, John, and Rothschild, Miriam, 1962, Release of hydrocyanic acid from crushed tissues of all stages in the life-cycle of species of the Zygaeninae (Lepidoptera): Nature, v. 193, no. 4810, p. 52-53.

Jones, R. S., 1970, Gold content of water, plants, and animals: U.S. Geol. Survey Circ. 625, 15 p.

Kingsbury, J. M., 1964, Poisonous plants of the United States and Canada: Englewood Cliffs, N.J., Prentice-Hall, Inc., $626 \mathrm{p}$.

Kinkel, A. R., Jr., and Lesure, F. G., 1968, Residual enrichment and supergene migration of gold, Southeastern United States, in Geological Survey research 1968: U.S. Geol. Survey Prof. Paper 600-D, p. D174-D178.

Krauskopf, K. B., 1951, The solubility of gold: Econ. Geology, v. 46, no. 8, p. $858-870$.

Küchler, A. W., 1964, Potential natural vegetation of the conterminous United States: Am. Geog. Soc. Spec. Pub. 36, map with 116 p. text.

1967, Potential natural vegetation, in National Atlas of the United States of America, 1970: U.S. Geol. Survey sheet 90.

Latimer, W. M., 1952, The oxidation states of the elements and their potentials in aqueous solutions [2d ed.]: Englewood Cliffs, N.J., Prentice-Hall, Inc., $392 \mathrm{p}$. 
Latimer, W. M., and Hildebrand, J. H., 1951, Reference book of inorganic chemistry [3d ed.]: New York, Macmillan Co., 625 p. [also published as second part of Hildebrand, J. H., and Powell, R. E., 1952, Principles of chemistry, 6th ed.: New York, Macmillan Co., 444 p.]

Listova, L. P., Vainshtein, A. Z., and Ryabinina, A. A., 1966, Dissolution of gold in media forming during oxidation of some sulfides: Akad. Nauk SSSR, Lab. Osad. Polez. Iskop., Metallogeniya Osad. Osad.-Metamorf. Porod, p. 189-199 (in Russian): [abs.] Chem. Abs., v. 68, [no.] 88967h, p. $8597,1968$.

Loughnan, F. C., 1969, Chemical weathering of the silicate minerals: New York, Am. Elsevier Publishing Co., Inc., 154 p.

Lovering, T. S., and Goddard, E. N., 1950: Geology and ore deposits of the Front Range, Colorado: U.S. Geol. Survey Prof. Paper 223, 319 p. [1951].

Lovering, T. S., and Morris, H. T., 1965, Underground temperatures and heat flow in the East Tintic district, Utah: U.S. Geol. Survey Prof. Paper 504-F, 28 p. [1966].

Lungwitz, E. E., 1900, The lixiviation of gold deposits by vegetation: Eng. and Mining Jour., v. 69, p. 500-502.

McCarthy, J. H., Learned, R. E., Botbol, J. M., Lovering, T. G., Watterson, J. R., and Turner, R. L., 1969, Gold-bearing jasperoid in the Drum Mountains, Juab and Millard Counties, Utah: U.S. Geol. Survey Circ. 623, 4 p.

Malte-Brun, M., 1824, Universal geography: Boston, Wells and Lilly, v. 1, $635 \mathrm{p}$.

Manskaya, S. M., and Drozdova, T. V., 1968, Geochemistry of organic substances (translated and edited by Leonard Shapiro and I. A. Breger) : New York, Pergamon Press, Internat. Ser. Mon. Earth Sci., v. 28, 345 p.

Miyake, Yasuo, 1965, Elements of geochemistry: Tokyo, Japan, Maruzen Co., Ltd., $475 \mathrm{p}$.

Morris, H. T., and Lovering, T. S., 1952, Supergene and hydrothermal dispersion of heavy metals in wallrocks near ore bodies, Tintic district, Utah: Econ. Geology, v. 47, no. 7, p. 685-716.

Palache, Charles, Berman, Harry, and Frondel, Clifford, 1944, Elements, sulfides, sulfosalts, oxides, v. 1, of The system of mineralogy of James Dwight Dana and Edward Salisbury Dana [7th ed.]: New York, John Wiley \& Sons, Inc., $834 \mathrm{p}$.

1951, Halides, nitrates, borates, carbonates, sulfates, phosphates, arsenates, tungstates, molybdates, etc., v. 2, of The system of mineralogy of James Dwight Dana and Edward Salisbury Dana [7th ed.] : New York, John Wiley \& Sons, Inc., 1124 p.

Parès, Y., 1964a, Action de Serratia marcescens dans le cycle biologique des métaux: Inst. Pasteur Annales, v. 107, no. 1, p. 136-141.

1964b, Action d'Agrobacterium tumefaciens dans la mise en solution de l'or: Inst. Pasteur Annales, v. 107, no. 1, p. 141-143.

1964c, Action de quelques bactéries hétérotrophes banales dans le cycle de l'or: Inst. Pasteur Annales, v. 107, no. 4, p. 573-575.

1966, La solubilisation de l'or par voie bactérienne (vue d'ensemble sur les recherches déjà effectuées) : Dakar Univ., Annales Faculte' Sci., v. 19, Sci. Végétales, no. 3, p. 167-172.

Parès, Y., and Cuper, J., 1964, Essai d'épuisement des latérites aurifères par voie bactérienne: Inst. Pasteur Annales, v. 107, no. 4, p. 568-573.

Parès, Y., and Giraud, J., 1964, Action des bactéries autotrophes dans le cycle de l'or: Inst. Pasteur Annales, v. 107, no. 4, p. 577-578. 
Parès, Y., Hans-Moevi, [C.,], Loko, H., and Gagnaire, L., 1965, Influence de la concentration du milieu de culture sur la mise en solution de l'or par voie bactérienne: Inst. Pasteur Annales, v. 108, no. 6, p. 815-819.

Parès, Y., and Martinet, R., 1964, Intervention des bactéries dans le cycle de l'or - Etude biologique du phénomène: Bur. Recherches Géologiques et Minieres Bull. 3 (Paris), p. 1-29.

Parès, Y., Martinet, R., Cuper, J., Giraud, J., Loko, H., Gagnaire, L., Mauvieux, L., and Prieira, M., 1965, Utilisation de milieux de culture de faible prix de revient pour la mise en solution de l'or par voie bactérienne: Inst. Pasteur Annales, v. 108, no. 5, p. 674-681.

Pascal, Paul, 1957, Nouveau traité de chimie minérale, v. 3: Paris, Masson et Cie, $838 \mathrm{p}$.

Patrick, Z. A., 1955, Toxic substances from microbial decomposition products of peach root residues, [Pt.] 2 of The peach replant problem in Ontario: Canadian Jour. Botany, v. 33, p. 461-486.

Ransome, F. L., 1911, Geology and ore deposits of the Breckenridge district, Colorado: U.S. Geol. Survey Prof. Paper 75, 187 p.

Rice, W. L., 1970, Investigation of a low-grade gold deposit in the Orogrande district, Idaho: U.S. Bur. Mines Rept. Inv. 7425, 14 p.

Rickard, T. A., 1897, The Enterprise Mine, Rico, Colorado: Am. Inst. Mining Engineers Trans., v. 26, p. 906-980.

Rose, T. K., 1898, The metallurgy of gold: London, Charles Griffin and Co., Ltd., 528 p.

Rott, E. H., Jr., 1931, Ore deposits of the Gold Circle mining district, Elko County, Nevada: Nevada Univ. Bull., v. 25, no. 5, 30 p.

Rowe, J. J., and Simon, F. O., 1968, The determination of gold in geologic materials by neutron-activation analysis using fire assay for the radiochemical separations: U.S. Geol. Survey Circ. 599, 4 p.

Shacklette, H. T., Lakin, H. W., Hubert, A. E., and Curtin, G. C., 1970, Absorption of gold by plants: U.S. Geol. Survey Bull. 1314-B, 23 p.

Skey, W., 1873, On the formation of gold nuggets in drift - Art. 55: New Zealand Inst., Trans. and Proc., 1872, v. 5, p. 377-383.

Spurr, J. E., and Garrey, G. H., 1908, Economic geology of the Georgetown quadrangle (together with the Empire district), Colorado, with General geology, by S. H. Ball: U.S. Geol. Survey Prof. Paper 63, 422 p.

Starkey, R. L., 1935, Isolation of some bacteria which oxidize thiosulfate: Soil Sci., v. 39, p. 197-215.

Stetefeldt, C. A., 1885, Russell's improved process for the lixiviation of silverores: Am. Inst. Mining Metall. Engineers Trans., v. 13, p. 47-118.

Stevenson, I. L., 1964, Biochemistry of soil, chap. 6, in Bear, F. E., ed., Chemistry of the soil [2d ed.] : New York, Reinhold Publishing Corp., p. 242-291.

Thompson, C. E., Nakagawa, H. M., and VanSickle, G. H., 1968, Rapid analysis for gold in geologic materials, in Geological Survey research 1968: U.S. Geol. Survey Prof. Paper 600-B, p. B130-B132.

Thornthwaite, C. W., 1941, Atlas of climatic types in the United States, 19001939 : U.S. Dept. Agriculture, Soil Conserv. Service Misc. Pub. 421, 7 p., 96 plates.

Timonin, M. I., 1941, Effect of by-products of plant growth on activity of fungi and actinomycetes, [Pt.] 3 of The interaction of higher plants and soil microorganisms: Soil Sci., v. 52, p. 395-413.

Tourtelot, H. A., 1968, Hydraulic equivalence of grains of quartz and heavier minerals, and implications for the study of placers: U.S. Geol. Survey Prof. Paper 594-F, 13 p. 
Tschiersch, B., 1967, Blausäure und Blausäureglykoside: Pharmazie, v. 22, p. $76-82$.

Turekian, K. K., and Wedepohl, K. H., 1961, Distribution of the elements in some major units of the earth's crust: Geol. Soc. America Bull., v. 72, no. 2 , p. $175-192$.

U.S. Department of Agriculture, 1938, Soils and men: U.S. Dept. Agriculture Yearbook, 1938, 1232 p.

1941, Climate and man: U.S. Dept. Agriculture Yearbook, 1941, 1248 p.

1951, Soil survey manual: U.S. Dept. Agriculture Handb. 18, 503 p.

1960, Soil classification - A comprehensive system, 7th approximation: U.S. Dept. Agriculture, Soil Conserv. Service, 265 p.

Valensi, G., 1963, Chimie generale, in Pourbaix, Marcel, Atlas Dequilibres Electrochimiques: Paris, Gauthier-Villars Cie., p. 56-67.

Vinogradov, A. P., 1959, The geochemistry of rare and dispersed chemical elements in soils [2d ed., revised]: New York, Consultants Bur., Inc., 209 p. (Translated from Russian.)

1962, Average contents of chemical elements in the principal types of igneous rocks of the earth's crust: Geokhimiya, no. 7, p. 555-571; Geochemistry, no. 7, p. 641-664.

Ward, G. M., and Durkee, A. B., 1956, Amygdalin content of peach tree tissues, [Pt.] 3 of The peach replant problem in Ontario: Canadian Jour. Botany, v. 34, p. 419-422.

Wells, J. D., Stoiser, L. R., and Elliott, J. E., 1969, Geology and geochemistry of the Cortez gold deposit, Nevada: Econ. Geology, v. 64, no. 5, p. 526-537.

White, Abraham, Handler, Philip, Smith, E. L., and Stetten, DeWitt, Jr., 1959, Principles of biochemistry [2d ed.] : New York, McGraw-Hill Book Co., Inc., $1,149 \mathrm{p}$.

White, D. E., Hem, J. D., and Waring, G. A., 1963, Chemical composition of subsurface waters, Chap. F, in Fleischer, Michael, ed., Data of geochemistry [6th ed.]: U.S. Geol. Survey Prof. Paper 440-F, 67 p.

Whitehead, D. C., 1964, Soil and plant-nutrition aspects of the sulphur cycle: Soils and Fertilizers, v. 27, no. 1, p. 1-8.

Wilson, S. H., 1966, Sulphur isotope ratios in relation to volcanological and geothermal problems: Bull. Volcanol., v. 29, p. 671-690.

Wrucke, C. T., Armbrustmacher, T. J., and Hessin, T. D., 1968, Distribution of gold, 'silver, and other metals near Gold Acres and Tenabo, Lander County, Nevada: U.S. Geol. Survey Circ. 589, 19 p.

Yamada, Yoshio, 1968, Occurrence of bromine in plants and soil: Talanta, v. 15, p. 1135-1141.

Youden, W. J., 1951, Statistical methods for chemists: New York, John Wiley \& Sons, Inc., $126 \mathrm{p}$.

Zajic, J. E., 1969, Microbial biogeochemistry: New York and London, Academic Press, 345 p. 

